\title{
Integrated Approach Towards the Application of Horizontal Wells to Improve Waterflooding Performance
}

\author{
Quarterly Report \\ July 1 - September 30, 1998
}

\author{
By \\ Mohan Kelkar \\ Chris Liner \\ Dennis Kerr
}

Work Performed Under Contract No.: DE-FC22-93BC14951

For

U.S. Department of Energy

Office of Fossil Energy

Federal Energy Technology Center

P.O. Box 880

Morgantown, West Virginia 26507-0880

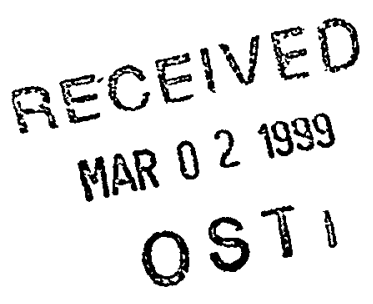

By

The University of Tulsa

Department of Geosciences

Tulsa, Oklahoma 74101 



\section{Disclaimer}

This report was prepared as an account of work sponsored by an agency of the United States Government. Neither the United States Government nor any agency thereof, nor any of their employees, makes any warranty, express or implied, or assumes any legal liability or responsibility for the accuracy, completeness, or usefulness of any information, apparatus, product, or process disclosed, or represents that its use would not infringe privately owed rights. Reference herein to any specific commercial product, process, or service by trade name, trademark, manufacturer, or otherwise does not necessarily constitute or imply its endorsement, recommendation, or favoring by the United States Government or any agency thereof. The views and opinions of authors expressed herein do not necessarily state or reflect those of the United States Government or any agency thereof. 


\section{DISCLAIMER}

Portions of this document may be illegible in electronic image products. Images are produced from the best available original document. 


\section{CONTENTS}

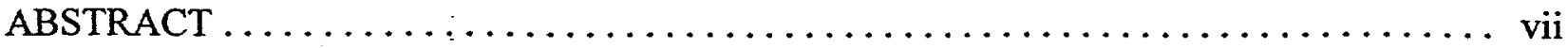

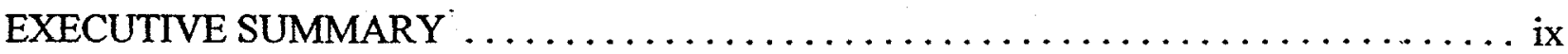

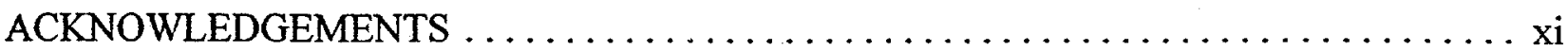

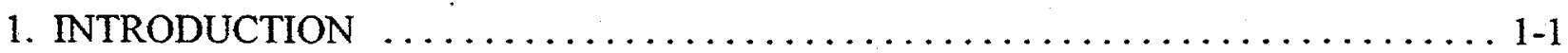

2. REGIONAL FACIES EVALUATION AND OUTCROP

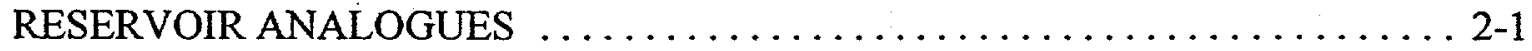

2.1 Regional Facies Evaluation ..............................

2.1.1 Paleogeographic Setting ............................ 2-1

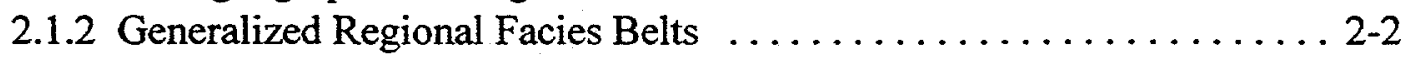

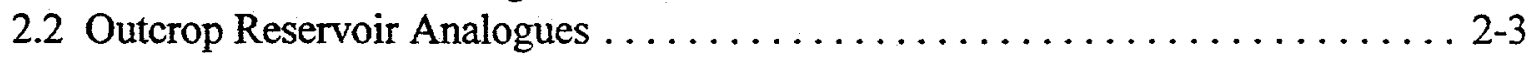

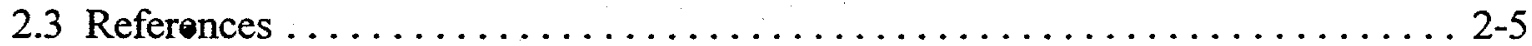

3. PROJECT FIELDS, NAVAJO NATION, SAN JUAN COUNTY, UTAH . . . . . . . 3-1

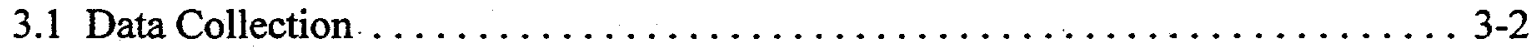

3.2 Field Studies $\ldots \ldots \ldots \ldots \ldots \ldots \ldots \ldots \ldots \ldots \ldots \ldots \ldots \ldots \ldots \ldots \ldots \ldots \ldots \ldots \ldots, 2$

3.2 .1 Runway Field $\ldots \ldots \ldots \ldots \ldots \ldots \ldots \ldots \ldots \ldots \ldots \ldots \ldots \ldots \ldots \ldots \ldots \ldots, 4$

3.2 .2 Heron North $\ldots \ldots \ldots \ldots \ldots \ldots \ldots \ldots \ldots \ldots \ldots \ldots \ldots, 3-5$

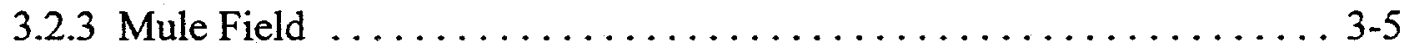

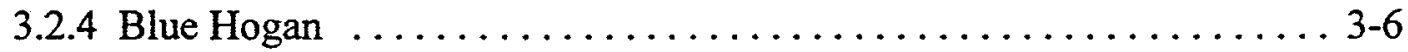

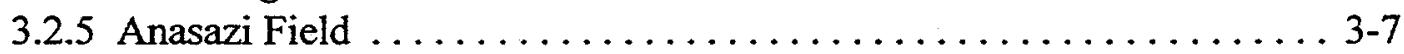

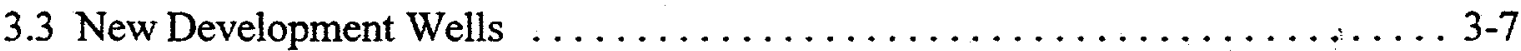

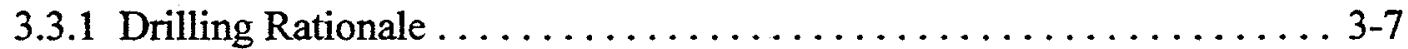

3.3.2 Anasazi No. $6 \mathrm{H}-1$ Well, Anasazi Field $\ldots \ldots \ldots \ldots \ldots \ldots \ldots \ldots . .6 \ldots$

3.4 References .................................... $3-11$

4. GEOLOGICAL CHARACTERIZATION OF THE CARBONATE

RESERVOIR IN THE DESERT $\ldots \ldots \ldots \ldots \ldots \ldots \ldots \ldots \ldots \ldots \ldots \ldots, 4-1$

4.1 Location, Geometry, and General Stratigraphy $\ldots \ldots \ldots \ldots \ldots \ldots \ldots \ldots$ 4-1

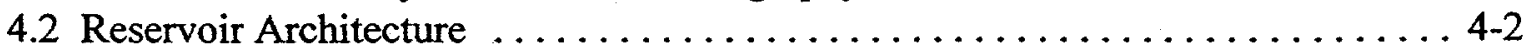

4.3 Reservoir Model Geometry $\ldots \ldots \ldots \ldots \ldots \ldots \ldots \ldots \ldots \ldots \ldots \ldots, 4,4$

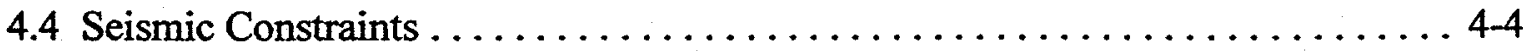

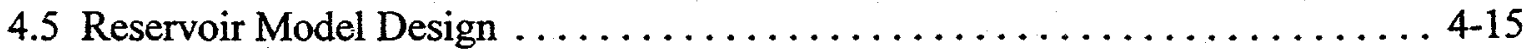

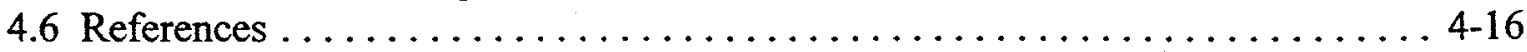

5. ENGINEERING RESERVOIR CHARACTERIZATION OF THE

CARBONATE RESERVOIR IN THE DESERT CREEK ZONE $\ldots \ldots \ldots \ldots \ldots .5$ - 1

5.1 Review of Existing Field Data and Re-evaluation of Well Test Data ....... 5-1

5.1.1 Field Data Review .......................... 5-1 
5.1 .2 Well Test Data Re-Evaluation $\ldots \ldots \ldots \ldots \ldots \ldots \ldots \ldots \ldots \ldots$. $\ldots \ldots \ldots$

5.2 Fluid Characterization . . . . . . . . . . . . . . . . . . .

5.2.1 Sample Preparation and Compositional Analysis . . . . . . . . . 5-7

5.2.1.1 Separator Oils. .................... 5-8

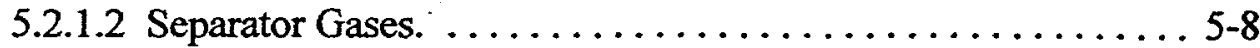

5.2 .1 .3 Dead Oil. ........................... 5-8

5.2.2 Fluid Recombination and Swelling Tests $\ldots \ldots \ldots \ldots \ldots \ldots . . \ldots 5$

5.2.2.1 Fluid Recombination. . . . . . . . . . . . . . . 5-9

5.2 .2 .2 Swelling Tests. . . . . . . . . . . . . . . . . . 5-9

5.2 .3 Separator Tests . . . . . . . . . . . . . . . . . . . 5-10

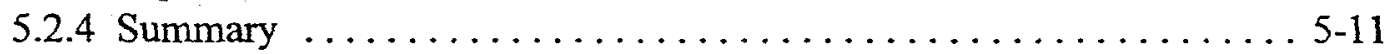

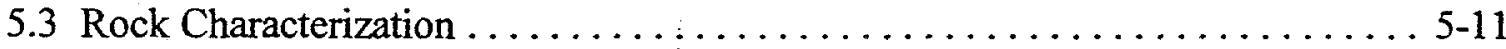

5.3 .1 Relative Permeability Measurements $\ldots \ldots \ldots \ldots \ldots \ldots \ldots$. $5-12$

5.3 .1 .1 Fluid Measurements. . . . . . . . . . . . . . . 5-12

5.3 .1 .2 Experimental Procedures. . . . . . . . . . . . . . 5-12

5.3.1.3 Resaturation and $\mathrm{K}_{\text {ew }}$ Measurements. . . . . . . . . 5-13

5.3.1.4 Initial Oil/Brine Drainage Experiment and Aging. . . . . . . 5-13

5.3.1.5 Brine/Oil Imbibition Capillary Pressure Test. . . . . . . . . . . 5-13

5.3.1.6 $\mathrm{K}_{\text {ew }}$ Measurements and Oil/Brine Secondary Drainage Test.

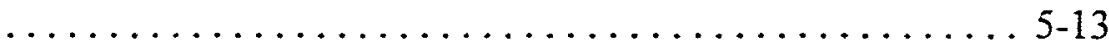

5.3.1.7 Brine/Oil Imbibition Relative Permeability Test. . . . . . . . 5-13

5.3.1.8 Oil/Brine Drainage Relative Permeability Test. . . . . . . . 5-16

5.3.1.9 Gas/Oil Capillary Pressure and Relative Permeability Experiment.

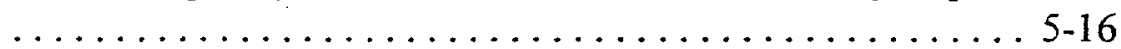

5.3.1.10 Final Saturation Determination via Dean-Stark. . . . . . . . 5-22

5.3.1.11 Gas Property Measurements. . . . . . . . . . . 5-22

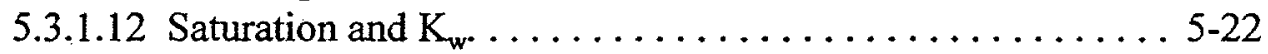

5.3.1.13 Primary Drainage Capillary Pressure Measurements. . . . 5 5-22

5.3.1.14 U.S. Bureau of Mines and Amott Wettability Indices. . . . 5 5-22

5.3.1.15 Bond Number versus $\mathrm{S}_{\mathrm{or}} / \mathrm{S}_{\mathrm{oi}} \cdot \ldots \ldots \ldots \ldots \ldots \ldots . \ldots \ldots$

5.3 .1 .16 Summary. ...................... . . . $5-23$

5.3 .2 Rock Compressibility Measurements . . . . . . . . . . . . 5-24

5.4 References ................................. 5-26

6. MECHANISTIC RESERVOIR SIMULATION STUDIES $\ldots \ldots \ldots \ldots \ldots \ldots \ldots \ldots \ldots$.

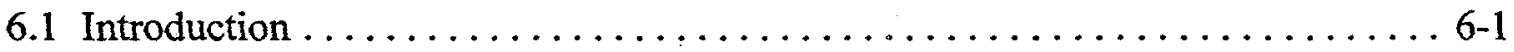

6.2 Model Description .............................. 6-1

6.3 Fluid Properties and Production Data $\ldots \ldots \ldots \ldots \ldots \ldots \ldots \ldots \ldots \ldots \ldots \ldots \ldots \ldots$

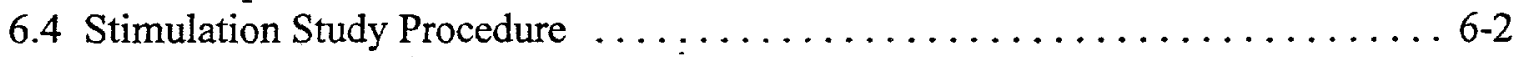

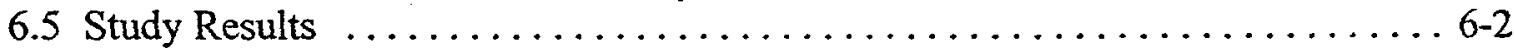

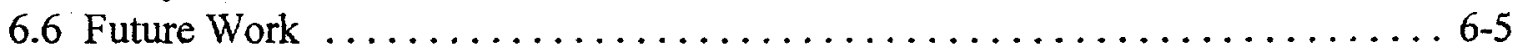

7. TECHNOLOGY TRANSFER $\ldots \ldots \ldots \ldots \ldots \ldots \ldots \ldots \ldots \ldots \ldots \ldots \ldots \ldots .1$

7.1 Utah Geological Survey Petroleum News and Survey Notes . . . . . . . . . 7-1

7.2 Workshops, Presentations, and the 1996 Paradox Basin Symposium . . . . . . 7-3 
7.3 Addressing Regulatory Issues .

APPENDIX A: PARADOX BASIN PROJECT FIELD SUMMARIES . . . . . . . . A-1

APPENDIX B: COMPOSITIONAL ANALYSES OF OIL AND GAS ........... B-1

APPENDIX C: SWELLING TEST DATA $\ldots \ldots \ldots \ldots \ldots \ldots \ldots \ldots \ldots \ldots \ldots \ldots$ 


\section{FIGURES}

Figure 1.1. Location of shallow-shelf carbonate fields, San Juan County, Utah targeted for

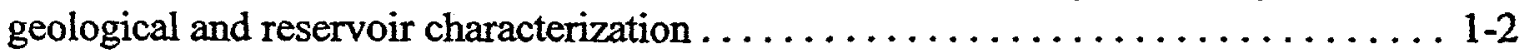

Figure 2.1. Generalized regional facies belts for Desert Creek zone, Pennsylvanian Paradox Formation, southeastern San Juan County, Utah . . . . . . . . . . . 2-2

Figure 2.2. Location of Paradox Formation outcrops in the Wild Horse Canyon area along the San Juan River, southeastern Utah . . . . . . . . . . . . . . . . . . . . 2-4

Figure 2.3. Outcrops in the Ismay zone of the Paradox Formation, Wild Horse Canyon near the San Juan River, southeastern Utah . . . . . . . . . . . . . . . . 2-4

Figure 3.1. Representative seismic line, shaded according to amplitude variations, across

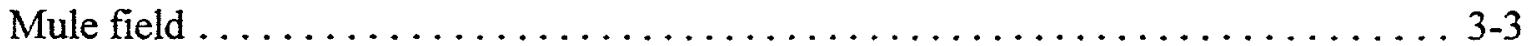

Figure 3.2. Three-dimensional "net" view on top of the Mississippian Leadville Limestone and the north-bounding faults which control the localization of small

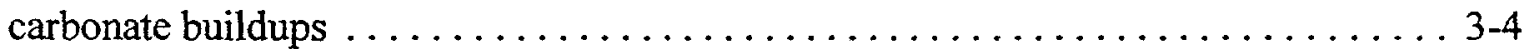

Figure 3.3. Core surface view of highly productive, dolomitized, phylloidal algal plate bafflestone from the Mule No. 31-M well, Mule field . . . . . . . . . . . 3-6

Figure 3.4. Location of the first project development well, the Anasazi No. $6 \mathrm{H}-1$, drilled in the Anasazi field $\ldots \ldots \ldots \ldots \ldots \ldots \ldots \ldots \ldots \ldots \ldots \ldots$

Figure 3.5. Set of CAT scans of two mutually perpendicular longitudinal-axial sections of core plugs taken from the Anasazi No. $6 \mathrm{H}-1$ well $\ldots \ldots \ldots \ldots \ldots \ldots \ldots \ldots \ldots$

Figure 4.1. Gross Desert Creek isopach, Anasazi field $\ldots \ldots \ldots \ldots \ldots \ldots \ldots \ldots \ldots \ldots$. . . . . .

Figure 4.2. Stratigraphic cross section across Anasazi field . . . . . . . . . . . . . 4-3

Figure 4.3. Computed geophysical well logs and lithology plots of the Desert Creek zone,

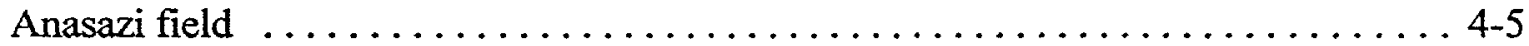

Figure 4.4. Photomicrographs of thin sections showing low-quality architectural lithotypes . 4-8

Figure 4.5. Photomicrographs of thin sections showing high-quality architectural

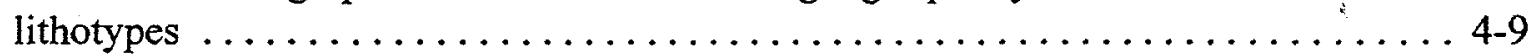

Figure 4.6. Photomicrographs of thin sections showing moderate- to high-quality

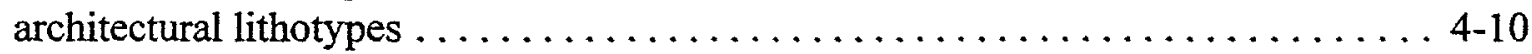

Figure 4.7. Photomicrograph of a thin section showing a phylloid algal bafflestone . . . . 4-11

Figure 4.8. Anasazi reservoir gridded isolith map . . . . . . . . . . . . . . 4-12

Figure 4.9. Reservoir quality index (RQI) map with seismic data points, Anasazi reservoir ................................ $4-13$

Figure 4.10. Estimation of average porosity from RQI, Anasazi reservoir . . . . . . 4-14

Figure 4.11. Map of average porosity derived from the RQI, Anasazi reservoir . . . . . . 4-15

Figure 5.1. Anasazi No. 1 well test displaying pressure difference and pressure derivative match. . . . . . . . . . . . . . . . . . . . . . . . . $5-5$

Figure 5.2. Anasazi No. 1 well test displaying superposition time vs. pressure match $\ldots \ldots 5-6$

Figure 5.3. Anasazi No. 1 well test displaying pressure vs. time match $\ldots \ldots \ldots \ldots \ldots \ldots 5$

Figure 5.4. Comparison of the weight percent composition measured for the flashed separator oil and dead oil samples $\ldots \ldots \ldots \ldots \ldots \ldots \ldots \ldots \ldots \ldots \ldots \ldots \ldots \ldots$

Figure 5.5. Brine.- oil primary imbibition capillary pressure curves for Anasazi No.

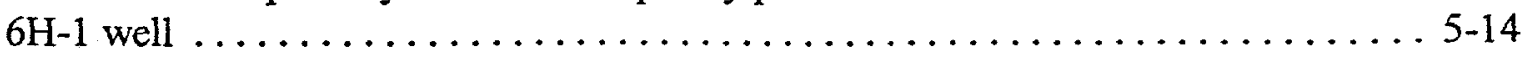


Figure 5.6. Oil - brine secondary drainage capillary pressure curves for Anasazi No.

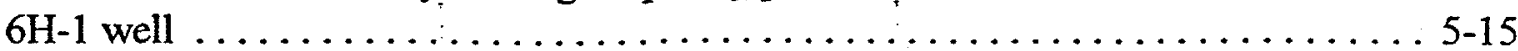

Figure 5.7. Oil - brine relative permeability curves for Anasazi No. $6 \mathrm{H}-1$ well $\ldots \ldots \ldots 5-16$

Figure 5.8. Oil - brine primary drainage capillary pressure curve for Anasazi No.

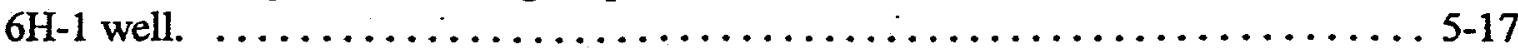

Figure 5.9. Gas - oil drainage capillary pressure curve for Anasazi No. $6 \mathrm{H}-1$ well $\ldots . . .55$

Figure 5.10. Gas - oil relative permeability curves for Anasazi No. $6 \mathrm{H}-1$ well . . . . . . 5-19

Figure 5.11. Bond number vs. $S_{o r} / S_{o i}$ curves for Anasazi No. $6 \mathrm{H}-1$ well $\ldots \ldots \ldots \ldots \ldots .53$

Figure 6.1. Results of two-dimensional reservoir simulation of the Anasazi field . . . . . . 6-3

Figure 6.2. Two-dimensional reservoir simulation of the Anasazi field showing gas

saturation for $\mathrm{XZ}$ plane after 1,461 days of production $\ldots \ldots \ldots \ldots \ldots \ldots \ldots .4$

Figure 6.3. Schematic reservoir simulator model of the Anasazi reservoir . . . . . . . 6 6-4

Figure 7.1. UGS Survey Notes and Petroleum News . . . . . . . . . . . . . 7-2

Figure 7.2. UGS-sponsored core workshop during the 1994 AAPG Annual Convention . . . 7-3 


\section{TABLES}

Table 3.1. Project fields in the Paradox basin, San Juan County, Utah. . . . . . . . . . . . 3-1

Table 3.2. Geological and engineering data for project fields in the Paradox basin, San Juan

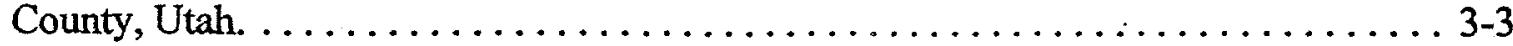

Table 4.1. Average reservoir properties of architectural lithotypes, Anasazi field. . . . . . 4-7

Table 5.1. Swelling test data for the Anasazi No. 5L-3 oil. . . . . . . . . . . . 5-10

Table 5.2. Separator test volumetric data ... . . . . . . . . . . . . . . . 5-10

Table 5.3. Separator test-produced GOR . . . . . . . . . . . . . . . . . . . . 5-11

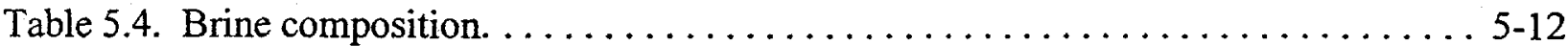

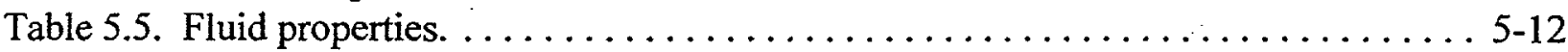

Table 5.6. Permeability and porosity data summary for the Anasazi No. $6 \mathrm{H}-1 \ldots \ldots . \ldots 5-20$

Table 5.7. Pre-test sample conditions and physical properties for selected samples from the

Anasazi Nos. 1 and $6 \mathrm{H}-1$ wells. . . . . . . . . . . . . . . . . . . . . . . 5-24

Table 5.8. Target pressures for simulated in-situ conditions. . . . . . . . . . . . . 5-25

Table 5.9. Compressibilities determined from hydrostatic compression for samples from the

Anasazi Nos. 1 and $6 \mathrm{H}-1$ wells. . . . . . . . . . . . . . . . . . . . 5-25

Table 5.10. Quasi-static mechanical properties determined from triaxial compression for samples from the Anasazi Nos. 1 and $6 \mathrm{H}-1$ wells. . . . . . . . . . . . . . 5-26

Table 5.11. Parameters determined during uniaxial strain/pore pressure drawdown

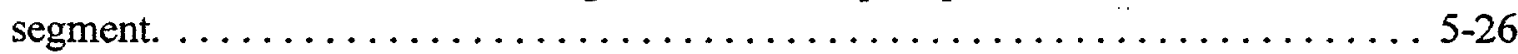

Table 6.1. Analysis of gravity drainage behavior. $\ldots \ldots \ldots \ldots \ldots \ldots \ldots \ldots \ldots \ldots \ldots$

Table B.1. Composition of Anasazi No. 5-L separator oil cylinder No. W8301 . . . . . . . . B-2

Table B.2. Composition of Anasazi No. 5-L separator oil cylinder No. W4635 . . . . . . . B-4

Table B.3. Composition of Anasazi No. 5-L separator gas cylinder No. 5EK088. . . . . . B-6

Table B.4. Composition of Anasazi No. 5-L separator gas cylinder No. 6EK087. . . . . . . B-7

Table B.5. Dead oil liquid composition of the Anasazi flashed separator oils and dead oils . . B-8

Table B.6. Composition of Anasazi No. 5-L recombined separator oil. . . . . . . . . . . B-10

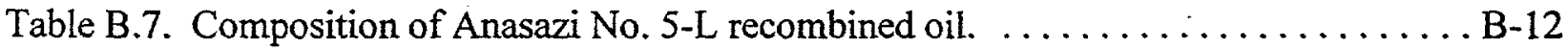

Table B.8. Vapor compositional data for the two separator tests. . . . . . . . . . . . B-14

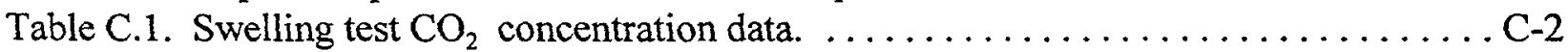

Table C.2. Relative volumes of the liquid and vapor phases as a function of pressure . . . . C-2

Table C.3. Properties of the saturated fluid with 20 mole percent $\mathrm{CO}_{2} \ldots \ldots \ldots \ldots \ldots$. $\ldots \ldots$

Table C.4. Relative volumes of the liquid and vapor phases as a function of pressure . . . . C-3

Table C.5. Properties of the saturated fluid with 40 mole percent $\mathrm{CO}_{2} \ldots \ldots \ldots \ldots \ldots$.

Table C.6. Relative volumes of the liquid and vapor phases as a function of pressure . . . . C-4

Table C.7. Visual determination of the bubble point pressure using small pressure drops for

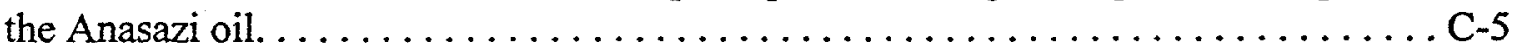

Table C.8. Properties of the saturated fluid with 60 mole percent $\mathrm{CO}_{2} \ldots \ldots \ldots \ldots \ldots$

Table C.9. Relative volumes of the liquid and vapor phases as a function of pressure . . . . C-6

Table C.10. Properties of the saturated fluid with 75 mole percent $\mathrm{CO}_{2} \ldots \ldots \ldots \ldots \ldots$ 


\section{ABSTRACT}

The Paradox basin of Utah, Colorado, and Arizona contains nearly 100 small oil fields producing from carbonate buildups or mounds within the Pennsylvanian (Desmoinesian) Paradox Formation. These fields typically have one to four wells with primary per field production ranging from 700,000 to $2,000,000$ barrels of oil at a 15 to 20 percent recovery rate. At least 200 million barrels of oil is at risk of being left behind in these small fields because of inefficient recovery practices and undrained heterogeneous reservoirs. Five fields (Anasazi, Mule, Blue Hogan, Heron North, and Runway) within the Navajo Nation of southeastern Utah are being evaluated for waterflood or carbon dioxide miscible flood projects based upon geological characterization and reservoir modeling. The results can be applied other fields in the Paradox basin and the Rocky Mountain region, the Michigan and Illinois basins, and the Midcontinent.

Three generalized facies belts are present in the Desert Creek zone of the Paradox Formation: (1) open marine, (2) shallow-shelf and shelf-margin, and (3) intra-shelf, salinity-restricted facies. Conventional cores show that the five fields are located in the shallow-shelf and shelf-margin facies belt and three compositional reservoir buildup types are present: (1) phylloid algal, (2) bioclastic calcarenite, and (3) bryozoan-dominated. Outcrops of the Paradox Formation Ismay zone along the San Juan River of southeastern Utah, provide small-scale analogues of the reservoir heterogeneity, flow barriers and baffles, and lithofacies geometry observed in the fields.

Procedures for quantitatively characterizing the Anasazi field reservoir have been defined and the required data assembled from a variety of sources. To adequately represent the observed spatial heterogeneities in reservoir properties, the mound-core interval phylloid algal bafflestones and overlying supra-mound interval dolomites have been subdivided into ten architecturally distinct lithotypes, each of which exhibits a characteristic set of reservoir properties. Geometries and patterns of spatial arrangement for these lithotypes have been inferred from the outcrop analogue studies and comparison with previous work in nearby Greater Aneth field. Reservoir properties and lithotype characterizations were obtained from cores and logs from the four Anasazi wells. Model constraints on lateral variation in average reservoir porosity and permeability are imposed by data obtained from six interpreted two-dimensional seismic lines and well test results. The initial three-dimensional reservoir model consists of 50,2 -foot $(0.6-\mathrm{m})$ layers on a $30 \times 50$-cell $(380$ acre [154 ha]) geographic grid, comprising a total of 75,000 grid blocks. A three-stage modeling procedure has been defined and implementation development is well underway; initial geostatistical models of the Anasazi reservoir should be available for conducting full-field simulation studies during the second project year.

The reservoir engineering component of the work completed to date in evaluating the potential of improved oil recovery for Paradox basin reservoirs includes analysis of production data and well test, comprehensive laboratory programs, and preliminary mechanistic reservoir simulation studies. Well test analysis indicated that dual-property models may be used to interpret the pressure response behavior of the Desert Creek zone. The laboratory work completed includes gas-oil and oil-brine relative permeability and capillary pressure measurements on new preserved cores. In addition, reservoir rock wettability measurements have been completed. Rock compressibility measurement on both supra-mound (dolomite) and mound-core (limestone) samples were completed and will be used to provide data to more reliably model the liquid expansion phase of Paradox basin reservoir production. 
A comprehensive fluid property characterization program has been completed. This work includes a suite of carbon dioxide swelling tests using Anasazi field crude oil. Data from this set of experiments, in conjunction with black oil pressure-volume-temperature data obtained on original fluid samples, will be used to calibrate an equation of state for future compositional simulation studies.

Mechanistic reservoir production performance simulation studies have also been completed. These studies were used to make a preliminary assessment of the primary production mechanistic behavior of Paradox basin reservoirs. To provide some initial insight into the basic production mechanism of the Anasazi reservoir some simple one- and two-dimensional compositional simulation studies were conducted prior to developing final reservoir description models and the final three-dimensional simulation study. The results showed that despite the major portion of production being from the mound-core interval there is not a corresponding decrease in the oil in place in the mound-core interval. This behavior clearly supports the gravity drainage of oil from the supra-mound interval into the lower mound-core interval from which the producing wells major share of production arises.

The results of this project were transferred to industry and other researchers through a petroleum extension service, a core workshop, displays at national and regional professional meetings, and publications in newsletters. 


\section{EXECUTIVE SUMMARY}

The primary objective of this project is to enhance domestic petroleum production by demonstration and technology transfer of an advanced oil recovery technology in the Paradox basin, southeastern Utah. If this project can demonstrate technical and economic feasibility, the technique can be applied to approximately 100 additional small fields in the Paradox basin alone, and result in increased recovery of 150 to 200 million barrels of oil. This project is designed to characterize five shallow-shelf carbonate reservoirs in the Pennsylvanian (Desmoinesian) Paradox Formation and choose the best candidate for a pilot demonstration project for either a waterflood or carbon dioxideflood project. The field demonstration, monitoring of field performance, and associated validation activities will take place within the Navajo Nation, San Juan County, Utah.

The Utah Geological Survey (UGS) leads a multidisciplinary team to determine the geological and reservoir characteristics of typical small shallow-shelf carbonate reservoirs in the Paradox basin. The Paradox basin project team consists of the UGS (prime contractor) Harken Southwest Corporation, and several subcontractors. This research is performed under the Class II Oil Program of the U.S. Department of Energy, Bartlesville Project Office. This report covers research and technology transfer activities from the pre-award period and first project year (June 10, 1995 through February 8, 1995). This work includes evaluation of regional facies belts, outcrop analogues, five selected fields, reservoir modeling, and simulation. The results can be applied to similar reservoirs in many U.S. basins.

Regionally three generalized facies belts were identified: (1) open marine, (2) shallow-shelf and shelf-margin, and (3) intra-shelf, salinity-restricted facies. Outcrops of the Paradox Formation Ismay zone along the San Juan River of southeastern Utah, provided small-scale analogues of reservoir heterogeneity, flow barriers and baffles, and lithofacies geometry. These characteristics are being used in reservoir simulation models for secondary/tertiary recovery of oil from the small fields in the basin.

Reservoir data, cores and cuttings, geophysical logs, various reservoir maps, and other information from the project fields and regional exploratory wells are being collected. Well locations, production reports, completion tests, core analysis, formation tops, and other data were compiled and entered in a database developed by the UGS. Base maps and new isochron maps covering project fields were prepared and cores were described from selected project wells with special emphasis on bounding surfaces of possible flow units.

The project fields (Anasazi, Mule, Blue Hogan, Heron North, and Runway) have one to three wells with primary per field production ranging from 700,000 to 2 million barrels of oil at a 15 to 20 percent recovery rate. Conventional cores from these fields show that three compositional reservoir types of carbonate buildups are present: (1) phylloid algal, (2) bioclastic calcarenite, and (3) bryozoan-dominated. Production, lithologic, basic reservoir parameters, and other data describing these fields were compiled and analyzed.

The first project development well, the Anasazi No. 6H-1, was spudded on May 20, 1995 and drilled to a total depth of 5,826 feet $(1,776 \mathrm{~m})$ in the Anasazi field, Navajo Nation, San Juan County, Utah. The principal reservoir evaluated, a carbonate buildup in the Desert Creek zone of the Paradox Formation. Evaluation of the core suggests the well missed the main buildup or mound-core interval (algal bafflestone reservoir) and penetrated poorer quality mound flank deposits (mixed carbonate fabrics that are brecciated, slumped, and chaotic) instead. However, the dolomites in the upper part of the buildup or supra-mound may be connected to the upper Anasazi reservoirs in the rest of the 
field. Selected plugs from the reservoir were used to determine oil/water and gas/oil relative permeability measurements; the results will be incorporated into the Anasazi reservoir flow simulation model.

A compositional simulation approach is being used to model various types of secondary/tertiary recovery processes. A compositional approach properly accounts for oil vaporization during primary depletion and will provide the correct oil compositions to subsequently assess carbon dioxide flooding potential. The main components of the engineering portion of the work are: (1) review of existing field data including re-evaluation of well test data, (2) reservoir fluid and rock characterizations via an extensive laboratory program, (3) reservoir development (history match, process design/evaluation for waterflood and carbon dioxide flood, and (4) economics. Assessment of the carbon dioxide process will require calibration of an equation of state using the following laboratory data acquired during the year for tuning: (1) compositional analysis on a recombined fluid sample, (2) a two-stage separator test, including a stock-tank condition, and (3) swelling tests. Relative permeability data, a key data sets required for reservoir recovery process evaluation via simulation, was obtained. Analysis of the resulting data from these measurements provide a valid data set for future reservoir simulation studies.

The simulation study is being conducted on the Anasazi field reservoir to investigate and compare processes of interest for various operational scenarios (including well placement, well type), geologic variation (that is various geostatistical realizations), and process variables. Based on simulation results economic viability can be assessed. Also, the simulation studies will provide the base design for an actual field test. The Anasazi reservoir is stratigraphically divisible into two distinctly different intervals: (1) a lower mound-core interval, consisting primarily of a thick, porous and highly permeable phylloid algal bafflestone, and (2) an overlying supra-mound interval, a sequence of heterogeneous dolomites (mudstones, packstones, wackestones, and grainstones) with lower permeability and higher average porosity than the underlying algal bafflestones.

Results of simple two-layer constant-property, two-dimensional numerical flow simulations indicate that although oil production rates are significantly higher in the permeable algal bafflestone of the mound-core interval, most of the oil resides in the overlying porous dolomites of the supra-mound interval. The results of these preliminary studies, along with field production data, show that as the oil is produced from the algal bafflestones, oil from the overlying dolomites continually replenishes the bafflestone pore system, resulting in a production capacity far greater than can be attributed to the mound-core interval alone.

Technology transfer for the project (pre-award period and first year) consisted of a displaying project materials at the UGS booth during the national and regional conventions of the American Association of Petroleum Geologists and the regional meeting of the Society of Petroleum Engineers. Presentations were made to geological societies and government officials. A core workshop was presented to industry representatives using materials from project fields. Newsletters were published detailing project progress and results. 


\section{ACKNOWLEDGEMENTS}

This research is performed under the Class II Oil Program of the U.S. Department of Energy (DOE), Bartlesville Project Office, contract number DE-FC22-95BC14988. The Contracting Officer's Representative is Rhonda P. Lindsey of the DOE Bartlesville Project Office. Additional funding is being provided by the Utah Office of Energy and Resource Planning, Jeff Burks, Director.

\section{Project Contributors:}

Principal Investigator: M.L. Allison; Utah Geological Survey, Salt Lake City, UT

Program Manager: $\quad$ T.C. Chidsey, Jr;; Utah Geological Survey, Salt Lake City, UT

Financial Officers: Werner Haidenthaller; Utah Geological Survey, Salt Lake City, UT

B.N. Huff; Harken Southwest Corp., Irving, TX

Task Contributing Scientists and Organizations:

R.L. Bon, T.C. Chidsey, Jr., M.D. Laine, C.D. Morgan, D.A. Sprinkel, K.A. Waite; Utah Geological Survey, Salt Lake City, UT

Marshall Watson, Wilson Groen, Kris Hartmann; Harken Southwest Corp., Irving, TX

W.E. Culham, D.M. Lorenz; REGA Inc., Houston, TX

D.E. Eby; Eby Petrography \& Consulting, Inc.; Littleton, $\mathrm{CO}_{\text {, }}$

Lisë Brinton; LithoLogic, Inc.; Englewood, CO

The following individuals and organizations provided valuable advice and data: Herb Mosca, Bligh Petroleum, Inc., Dallas, TX; P.G. Moreland, Geologic Consultant, Denver, CO; and John Johnson, Minerals Department, Navajo Nation, Window Rock, AZ.

Thanks is given to B.G. Hill, Utah Division of Oil, Gas and Mining, Salt Lake City, UT, for providing project base maps and other services.

This report or portions of it were reviewed by Bryce Tripp and W.R. Lund. 


\section{INTRODUCTION}

Thomas C. Chidsey, Jr.

Utah Geological Survey.

Over 400 million barrels of oil have been produced from shallow-shelf carbonate reservoirs in the Pennsylvanian (Desmoinesian) Paradox Formation in the Paradox basin of Utah, Colorado, and Arizona. With the exception of the giant Greater Aneth field, 100 plus oil fields in the basin typically contain 2 to 10 million barrels of original oil in place. To date, none of these small fields have been the site of secondary/tertiary recovery techniques used in large carbonate reservoirs. Most of these fields are characterized by extremely high initial production rates followed by a very short production life (primary) and hence early abandonment. At least 200 million barrels of oil is at risk of being left behind in these small fields because of inefficient recovery practices and undrained heterogeneous reservoirs. The purpose of this multi-year project is to enhance domestic petroleum production by demonstration and technology transfer of an advanced oil recovery technology in the Paradox basin.

The benefits to be ultimately be gained from the project are: (1) increased recoverable reserves by identifying untapped compartments created by reservoir heterogeneity, (2) increased deliverability through a waterflood or carbon dioxide $\left(\mathrm{CO}_{2}\right)$ miscible flood which exploits the reservoir along optimal fluid-flow paths, (3) identification of reservoir trends for field extension drilling and stimulating exploration in Paradox basin fairways, (4) causing technology to be used in other identified basins with similar types of reservoirs, (5) preventing premature abandonment of numerous small fields, (6) reducing development costs by more closely delineating minimum field size and other parameters necessary to a successful flood, (7) allowing limited energy investment dollars to be used more productively, and (8) increased royalty income to the Navajo Nation, Federal, State, and local governments, and fee owners. These benefits will be applied other areas in the Rocky Mountain region, the Michigan and Illinois basins, and the Midcontinent.

The geological and reservoir characteristics of five fields (figure 1.1) which produce oil and gas from the Desert Creek zone of the Paradox Formation are being quantitatively determined by a multidisciplinary team. The best candidate for a pilot waterflood or $\mathrm{CO}_{2}$ flood demonstration project will be chosen after a reservoir simulation has been completed. To evaluate these fields as models for other shallow-shelf carbonate reservoirs, the Utah Geological Survey (UGS), Harken Southwest Corporation, Eby Petrography \& Consulting Inc., LithoLogic, and REGA Inc. entered into a cooperative agreement with the U.S. Department of Energy as part of its Class II Oil program.

A two-phase approach is being used to increase production and reserves from the shallowshelf carbonate reservoirs in the Paradox basin. Phase I is the geological and reservoir characterization of the five small fields. Work during the first year and continuing into the second year of this phase includes: (a) determination of regional geological setting, (b) analysis of sequence stratigraphic framework to define and predict reservoir development and continuity, (c) drilling a development well(s), (d) field scale geologic analysis to focus on the reservoir heterogeneity, quality, and lateral continuity versus compartmentalization, (e) extensive reservoir mapping, (f) determination of field reserves and recovery, $(\mathrm{g})$ various laboratory tests and analogies to large scale waterfloods $/ \mathrm{CO}_{2}$ floods, (h) reservoir simulation, and (i) determination of the economic viability of secondary/tertiary recovery options. 


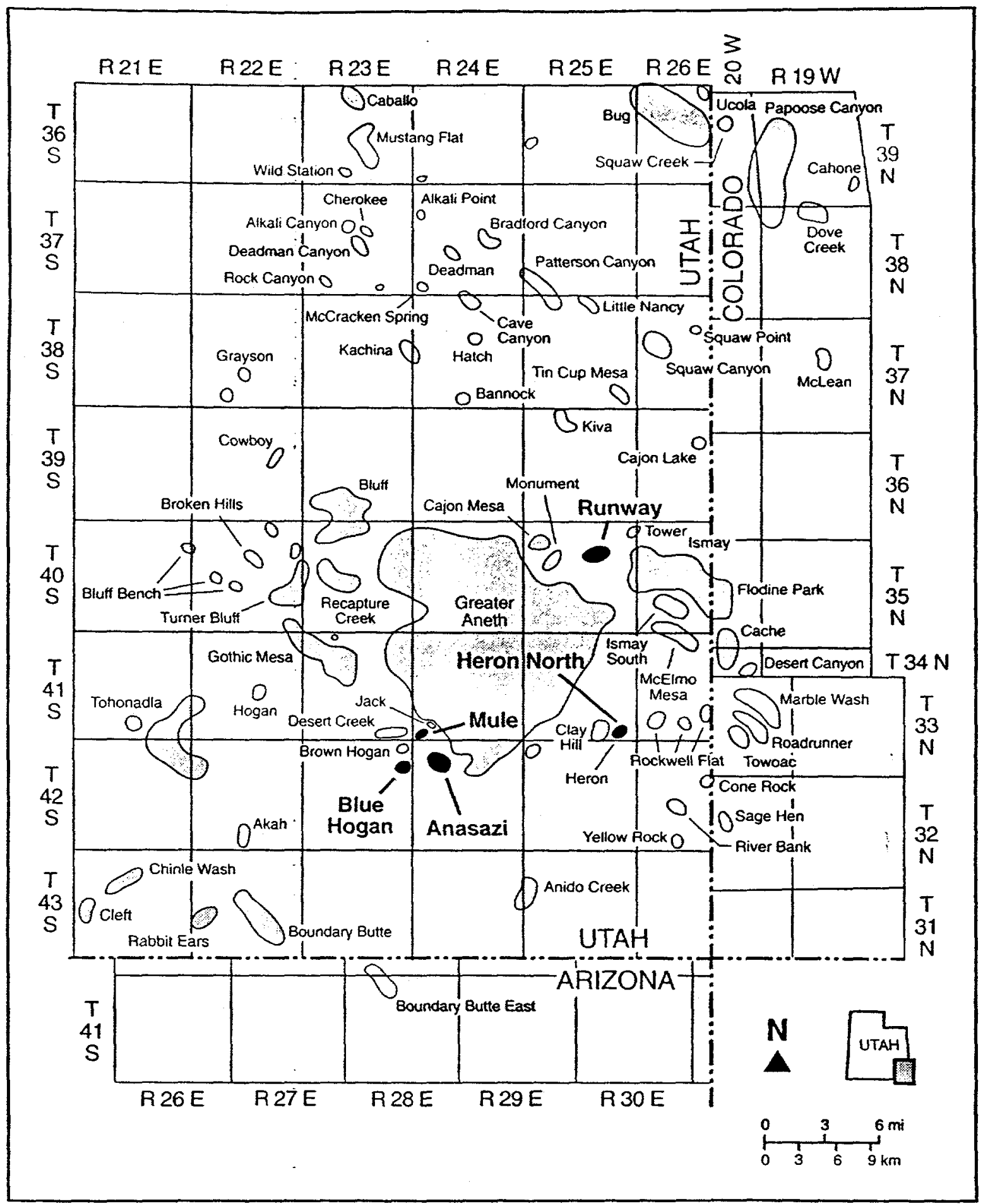

Figure 1.1. Five shallow-shelf carbonate fields (dark shading with names in bold type) on the Navajo Nation, San Juan County, Utah are targeted for geological and reservoir characterization. 
Phase II will be a demonstration project on the field selected from the characterization study using the secondary/tertiary recovery techniques identified as having the greatest potential for increased well productivity and ultimate recovery. The demonstration project will include: (a) drilling a development well to facilitate sweep during the pilot flood, (b) acquiring $\mathrm{CO}_{2}$ and/or water source for the flood project, (c) installation of $\mathrm{CO}_{2}$ and/or waterflood injection facilities, (d) conversion of a producing well to injection, (e) flood management, monitoring, and evaluation of results, and ( $f$ ) determining the application of the project to other similar fields in the Paradox basin and throughout the U.S.

The results of this project are being transferred to industry and other researchers through a petroleum extension service, creation of digital databases for distribution, technical workshops and seminars, field trips, technical presentations at national and regional professional meetings, and publication in newsletters and various technical or trade journals.

This report is organized into seven sections: (1) Introduction, (2) Regional Facies Evaluation and Outcrop Analogues, (3) Project Fields, Navajo Nation, San Juan County, Utah, (4) Geological Characterization of the Carbonate Reservoir in the Desert Creek Zone, (5) Engineering Reservoir Characterization of the Carbonate Reservoir in the Desert Creek Zone, (6) Mechanistic Reservoir 'Simulation Studies, and (7) Technology Transfer. There three appendices: (A) Paradox Basin Project Fields Summaries, (B) Compositional Analyses of Oil and Gas, Anasazi Field, and (C) Swelling Test Data, Anasazi Field. This report presents the progress of on-going research and is not intended as a final report. Whenever possible, preliminary conclusions have been drawn based on available data. 


\title{
2. REGIONAL FACIES EVALUATION AND OUTCROP RESERVOIR ANALOGUES
}

\author{
Thomas C. Chidsey, Jr. \\ Utah Geological Survey \\ Lisë Brinton \\ LithoLogic, Inc. \\ and \\ David E. Eby \\ Eby Petrography \& Consulting, Inc.
}

\subsection{Regional Facies Evaluation}

Establishment of the general regional facies belts and stratigraphic patterns within the shallow-shelf carbonate Desert Creek zone of the Paradox Formation for the southern Paradox basin is critical to: (1) understanding reservoir heterogeneity and capacity of the five fields being evaluated for the pilot demonstration and (2) exploring areas in the basin that have the greatest petroleum potential. Generalized regional facies belts for the Desert Creek zone (figure 2.1) were mapped utilizing conventional cores (more than 30 ), rotary sidewall cores, cuttings descriptions, and geophysical log interpretations.

\subsubsection{Paleogeographic Setting}

The Paradox basin was a structural and depositional trough associated with the Pennsylvanian-age Ancestral Rocky Mountains. The subsiding basin developed a shallow-water carbonate shelf which locally contained carbonate buildups on the south and southwest margins. These carbonate buildups and the material shed from their flanks formed petroleum traps where reservoir-quality porosity and permeability have developed.

During Pennsylvanian time, the Paradox basin was in subtropical, dry climatic conditions along the trade-wind belt, $10^{\circ}$ to $20^{\circ}$ north of the paleo-equator. Prevailing winds were from present day north (Peterson and Hite, 1969; Heckel, 1977; Parrish, 1982). Open-marine waters flowed across the shallow cratonic shelf into the basin during transgressive periods. There are four postulated directions for normal marine access into the Paradox basin. The Cabezon accessway, which was located to the southeast, is generally accepted as the most likely normal marine-water conduit to maintain circulation on the shallow shelf (Fetzner, 1960; Ohlen and McIntyre, 1965; Hite, 1970).

Cycles in Paradox basin deposition were primarily controlled by glacio-eustatic fluctuation. The shape of the sea-level curves reflects rapid marine transgressions (rapid melting of ice caps) and slow, interrupted regression (slow ice cap buildup) (Imbrie and Imbrie, 1980; Denton and Hughes, 1983; Heckel, 1986). Irregular patterns within the cycles are predicted in response to interference of orbital parameters (Imbrie and Imbrie, 1980). These cycles were also influenced by: (1) regional tectonic activity and basin subsidence (Baars, 1966; Baars and Stevenson, 1982), (2) proximity to basin margin and evaporites (Hite, 1960; Hite and Buckner, 1981), (3) climatic variation and 


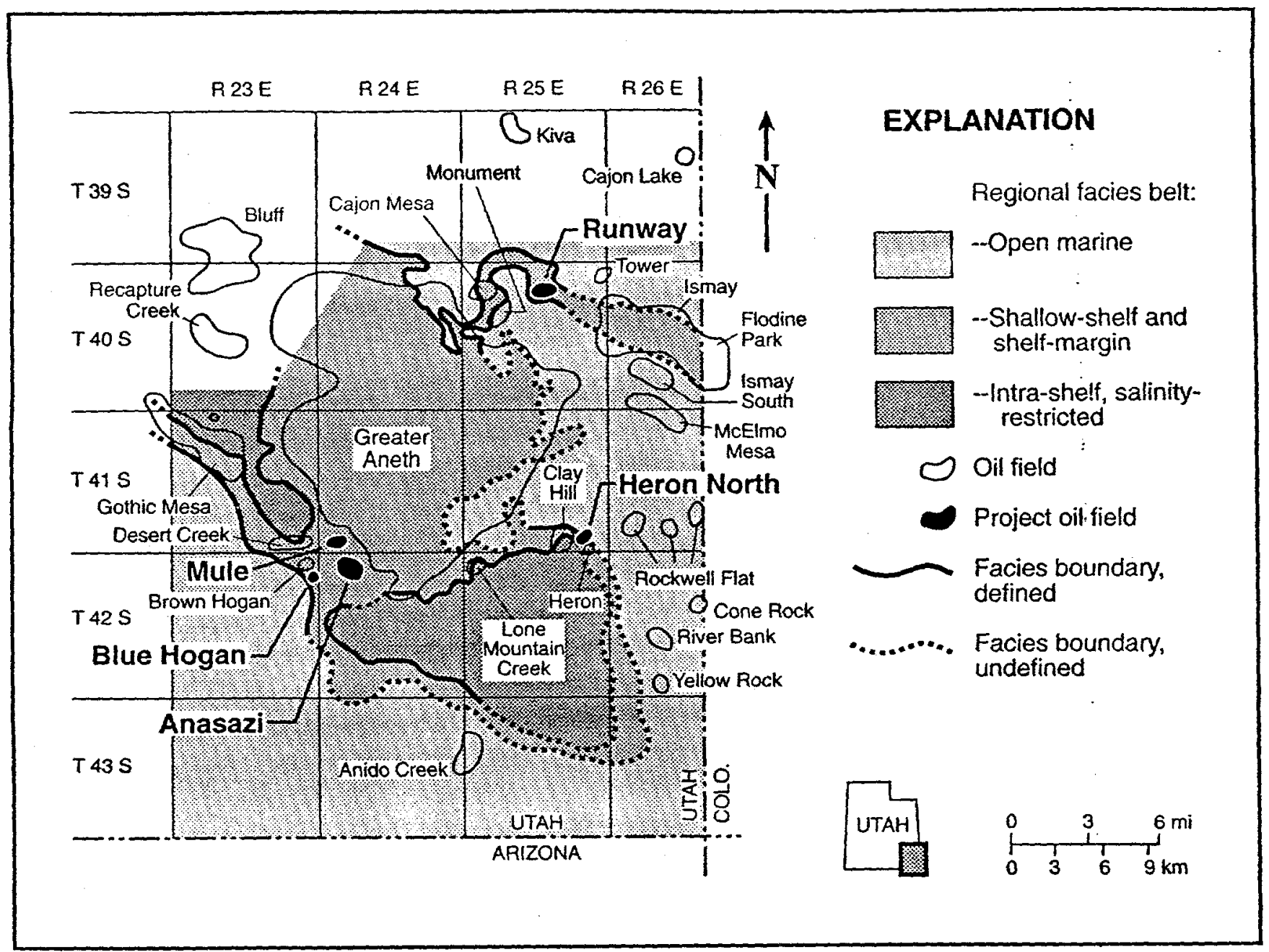

Figure 2.1. Generalized regional facies belts for Desert Creek zone, Pennsylvanian Paradox Formation, southeastern San Juan County, Utah.

episodic blockage of open marine-water conduits, and (4) fluctuations in water depth and water energy (Peterson and Ohlen, 1963; Peterson, 1966; Hite and Buckner, 1981; Heckel, 1983).

\subsubsection{Generalized Regional Facies Belts}

Three generalized regional facies belts are identified (figure 2.1): (1) open marine, (2) shallow-shelf and shelf-margin, and (3) intra-shelf, salinity-restricted facies. The open-marine facies belt includes open-marine buildups (typically crinoid-rich mounds), open-marine crinoidal- and brachiopod-bearing carbonate muds, euxinic black shales, wall complexes, and detrital fans. Openmarine facies were deposited at water depths between 90 and 120 feet $(27-37 \mathrm{~m})$. This facies belt is the most extensive and surrounds the shallow-shelf and shelf-margin facies belt. 
The shallow-shelf and shelf-margin facies belt includes shallow-shelf buildups (phylloid algal, coralline algal, bryozoan, and marine-cemented buildups [mounds]), calcarenites (beach, dune, and stabilized grain flats), and platform-interior carbonate muds and sands. These facies were deposited at water depths between 0 and 40 feet $(0-12 \mathrm{~m})$. Karst characteristics are occasionally present over mounds. Tubular tempestites (burrows filled with coarse sand as a result of storm pumping) are found in some carbonate muds and sands. Most oil fields which produce from the Desert Creek zone of the Paradox Formation are located within this facies belt including the giant Greater Aneth field (figure 2.1).

The intra-shelf, salinity-restricted facies belt represents small subbasins within the shallowshelf and shelf-margin facies belt. The water had slightly elevated salinity than was present in the other facies belts. This facies belt includes platform-interior evaporites, dolomitized tidal-flat muds, bioclastic lagoonal muds, tidal-channel carbonate sands and stromatolites, and euxinic dolomites. These facies were deposited at water depths between 20 and 45 feet (6-14 m). Euxinic dolomites often display karst characteristics. Two intra-shelf subbasins have been identified in the southeastern part of the Paradox basin in Utah; each is separated from the open-marine facies belt by a fringe of the shallow-shelf and shelf-margin facies belt (figure 2.1).

Mounds, tidal channel carbonate sands, and other features often appear promising on seismic records. However, if these carbonate buildups are located within the open-marine and intra-shelf, salinity-restricted facies belts, the reservoir quality is typically poor. Porosity and permeability development is limited or, if present, plugged with anhydrite in these respective facies belts. Mounds and calcarenite in the shallow-shelf and shelf-margin facies belt can have excellent reservoir properties; all five project fields are located within this facies belt.

\subsection{Outcrop Reservoir Analogues}

Outcrops of the Paradox Formation Ismay zone in the Wild Horse Canyon area along the San Juan River of southeastern Utah (figure 2.2), provide small-scale analogues of reservoir heterogeneity, flow barriers and baffles, and lithofacies geometry. These characteristics can be used in reservoir simulation models for secondary/tertiary recovery of oil from small fields in the basin. Quantitative data was gathered from several selected outcrops. These data included: (1) the sizes, shapes, orientations, and stratigraphic positions of units within the mounds, (2) facies relationships, and (3) gross reservoir properties of the key mound storage units, flow units, and permeability barriers. The outcrop work involved: (1) photographing mounds to create interpretive photomosaics, (2) measuring and describing stratigraphic sections, (3) mapping the areal extent of the mounds and associated facies, and (4) collecting representative samples for thin-section analysis. Major elements of reservoir architecture, lateral variations in reservoir properties, and definition of an internal "representative elementary volume" for modeling fluid storage and flow in each key facies were particularly emphasized.

From this work, it was determined that exposures of the Ismay zone (figure 2.3A) display lateral facies changes from phylloid algal mounds to off-mound detrital wedges or fans bounded at the top by a flooding surface. The phylloid mounds are composed of bafflestone (figure 2.3B), skeletal grainstone, packstone, and cementstone. Algal plates, brachiopods, bryozoans, and rugose corals are commonly found in the phylloid mounds. The mound wall is composed of rudstone, 


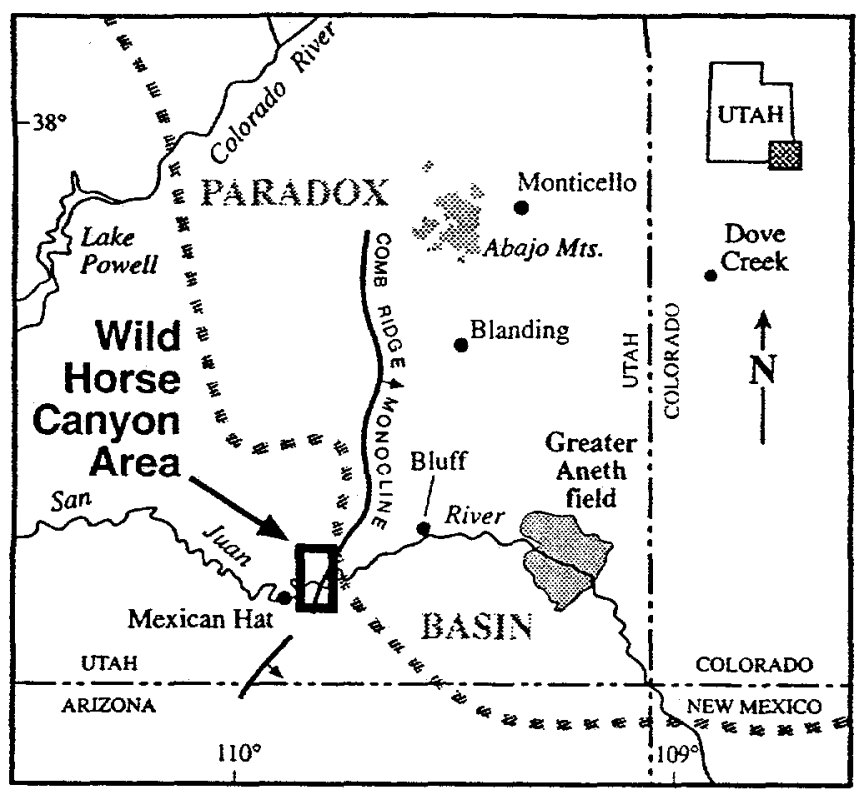

$\overbrace{0}^{0} \begin{aligned} & 10 \quad 20 \text { KLOMETERS } \\ & 10\end{aligned}$
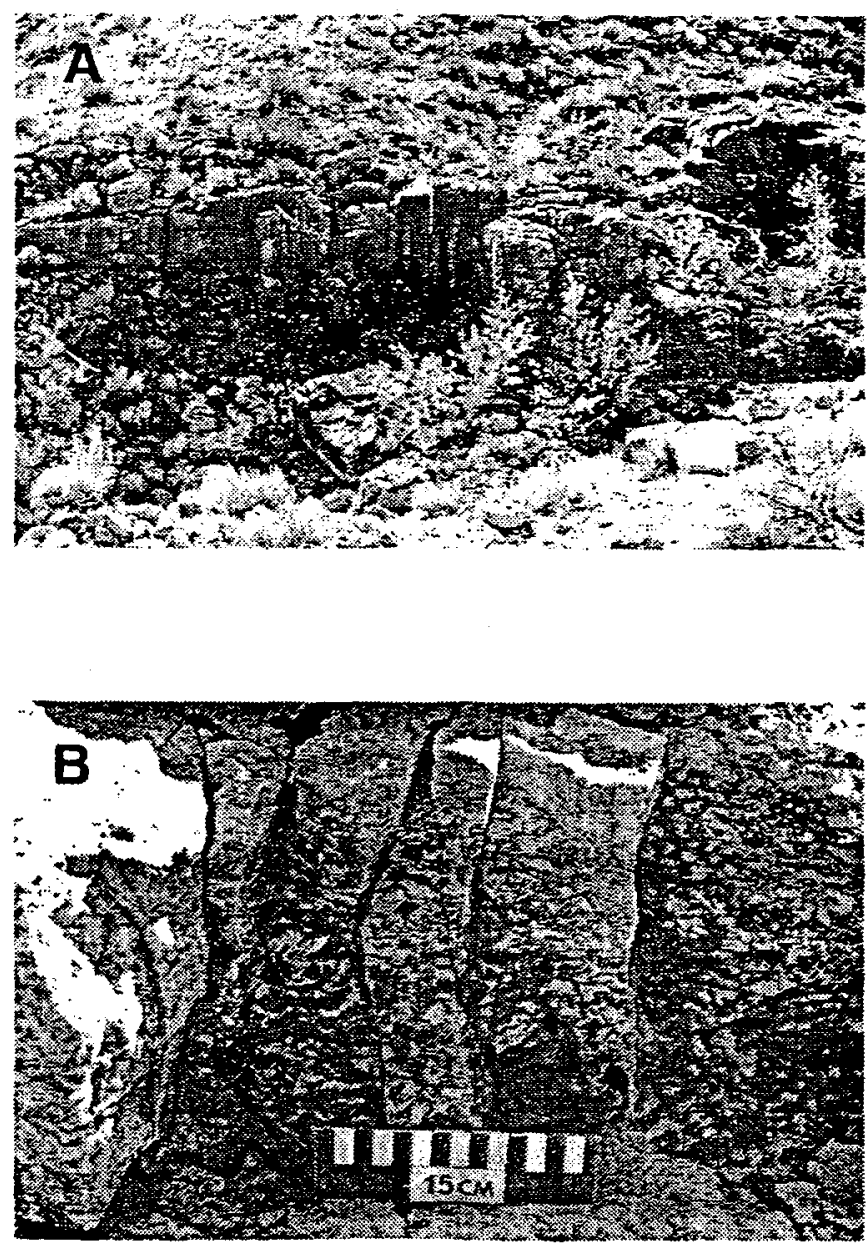

Figure 2.2. Location of Paradox Formation outcrops in the Wild Horse Canyon area along the San Juan River, southeastern Utah.
Figure 2.3. Outcrops in the Ismay zone of the Paradox Formation, Wild Horse Canyon near the San Juan River, southeastern Utah. (A) Typical phylloid mound composed of algal bafflestone, skeletal grainstone, and packstone. A flooding surface is present at the top of the mound. (B) Cement-rich algal bafflestone exposed in a phylloid mound. Original sheltered pore spaces were filled with mud; cement rinds are developed around algal plates. 
lumpstone, and cementstone. The detrital fan consists of transported algal material, grainstone, and mudstone with open-marine fossils. Within the mound complex are inter-mound troughs tentatively interpreted to be tidal channels. The geometry and composition of the rocks in the troughs significantly add to the overall heterogeneity of the mounds.

The results of these field investigations have been incorporated into the geological constraints on facies distributions in the geostatistical models. Reservoir models are being developed for possible water- and $\mathrm{CO}_{2}$ floods of small Paradox basin fields to determine the most effective secondary/tertiary recovery method. The models will include lithologic fabrics, flooding surfaces, and inter-mound troughs, based on the mound complex exposed at Wild Horse Canyon.

\subsection{References}

Baars, D.L., 1966, Pre-Pennsylvanian paleotectonics-key to basin evaluation and petroleum occurrences in Paradox basin, Utah and Colorado: American Association : of Petroleum Geologists Bulletin, v. 50, no. 10, p. 2082-2111.

Baars, D.L., and Stevenson, G.M., 1982, Subtle stratigraphic traps in Paleozoic rocks of Paradox basin, in Halbouty, M.T., editor, The deliberate search for the subtle trap: American Association of Petroleum Geologists Memoir 32, p. 131-158.

Denton, G.H., and Hughes, T.J., 1983, Milankovitch theory of ice ages: hypothesis of ice-sheet linkage between regional insolation and global climate: Quaternary Research, v. 20, p. 125144.

Fetzner, R.W., 1960, Pennsylvanian paleotectonics of the Colorado Plateau: American Association of Petroleum Geologists Bulletin, v. 44, no. 8, p. 1371-1413.

Heckel, P.H., 1977, Origin of phosphatic black shale facies in Pennsylvanian cyclothems of MidContinent North America: American Association of Petroleum Geologists Bulletin, v. 61, no. 7 , p. 1045-1068.

Heckel, P.H., 1983, Diagenetic model for carbonate rocks in midcontinent Pennsylvanian eustatic cyclothems: Journal Sedimentary Petrology, v. 53, p. 733-759.

Heckel, P.H., 1986, Sea-level curve for Pennsylvanian eustatic marine transgressive-regressive depositional cycles along midcontinent outcrop belt, North America: Geology, v. 14, p. 330334.

Hite, R.J., 1960, Stratigraphy of the saline facies of the Paradox Member of the Hermosa Formation of southeastern Utah and southwestern Colorado, in Geology of the Paradox basin: Four Corners Geological Society, Third Field Conference, p. 86-89.

Hite, R.J., 1970, Shelf carbonate sedimentation controlled by salinity in the Paradox basin, southeast Utah, in Ran, J.L., and Dellwig, L.F., editors, Third symposium on salt: Northern Ohio Geological Society, v. 1, p. 48-66. 
Hite, R.J., and Buckner, D.H., 1981, Stratigraphic correlation, facies concepts and cyclicity in Pennsylvanian rocks of the Paradox basin, in Wiegand, D.L., editor, Geology of the Paradox basin: Rocky Mountain Association of Geologists 1981 Field Conference, p. 147-159.

Imbrie, John, and Imbrie, J.Z., 1980, Modeling the climatic response to orbital variations: Science, v: 207, p. 943-953.

Ohlen, H.R., and McIntyre, L.B., 1965, Stratigraphy and tectonic features of Paradox basin, Four Corners area: American Association of Petroleum Geologists Bulletin, v. 49, no. 11, p. 2020-2040.

Parrish, J.T., 1982, Upwelling and petroleum source beds, with reference to the Paleozoic: American Association of Petroleum Geologists Bulletin, v. 66, no. 6, p. 750-774.

Peterson, J.A., 1966, Stratigraphic vs. structural controls on carbonate-mound accumulation, Aneth area, Paradox basin: American Association of Petroleum Geologists Bulletin, v. 50, no. 10, p. 2068-2081.

Peterson, J.A., and Hite, R.J., 1969, Pennsylvanian evaporite-carbonate cycles and their relation to petroleum occurrence, southern Rocky Mountains: American Association Petroleum Geologists Bulletin, v. 53, no. 4, p. 884-909.

Peterson, J.A., and Ohlen, H.R., 1963, Pennsylvanian shelf carbonates, Paradox basin, in Bass, R.O., editor, Shelf carbonates of the Paradox basin: Four Corners, Geological Society Symposium, 4th Field Conference, p. 65-79. 


\title{
3. PROJECT FIELDS, NAVAJO NATION, SAN JUAN COUNTY, UTAH
}

\author{
Thomas C. Chidsey, Jr. \\ Utah Geological Survey \\ Marshall Watson, Wilson Groen, and Kris Hartmann \\ Harken Southwest Corp. \\ and \\ David E. Eby
}

Eby Petrography \& Consulting, Inc.

The five Paradox basin fields being evaluated in Phase I of the project are Runway, Heron North, Anasazi, Mule, and Blue Hogan located within the Navajo Nation of southeast Utah (figure 1.1); they are five of several satellite carbonate mounds around the giant Greater Aneth field. This evaluation included data collection, core analysis and description, reservoir mapping, and drilling the first of possibly three development wells.

Eby and others (1993) have identified from core, five different types of carbonate buildups or mounds in the Desert Creek zone of the Paradox Formation: (1) crinoid/sponge mounds, (2) coralline algal "reefs" mounds, (3) bryozoan-dominated mounds, (4) phylloid algal mounds, and (5) bioclastic calcarenites "beach" mounds. The controls on the development of each mound type were water depth, prevailing wave energy, and paleostructural position. Examination of core from the five project fields shows that three mound types are present (table 3.1), making them good representatives of Desert Creek zone reservoirs. The geological and reservoir characterization of these fields and resulting models can applied to similar fields in the basin (and other basins as well) where data might be limited. The following presents the initial results of these efforts.

Table 3.1. Project fields in the Paradox basin, San Juan County, Utah.

\begin{tabular}{|c|c|c|c|c|c|}
\hline 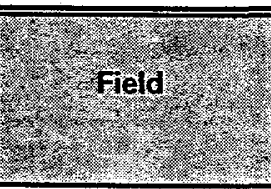 & 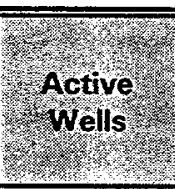 & 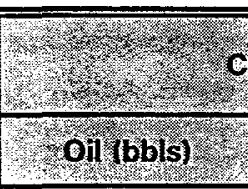 & $\begin{array}{l}\text { mulative Producti } \\
\text { Gas (MCF) }\end{array}$ & 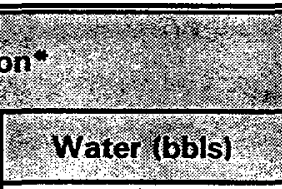 & $\begin{array}{l}\text { Bullap Type } \\
\text { But }\end{array}$ \\
\hline Anasazi & 4 & $1,650,133$ & $1,281,713$ & 25,274 & Phylloid Algal \\
\hline Blue Hogan & 1 & 282,718 & 256,006 & 1,699 & Phylloid Algal \\
\hline Mule & 2 & 343,180 & 203,116 & 17,930 & Phylloid Algal \\
\hline Heron North & 1 & 200,759 & 305,669 & 23,578 & Bioclastic Calcarenite \\
\hline Runway & 3 & 750,772 & $2,268,636$ & 3,036 & $\begin{array}{l}\text { Bryozoan-dominated/ } \\
\text { Phylloid Algal }\end{array}$ \\
\hline
\end{tabular}

*As of January 1, 1996 (Utah Division of Oil, Gas and Mining, 1996). 


\subsection{Data Collection}

Reservoir data, cores and cuttings, geophysical logs, various reservoir maps, and other information from the project fields and regional exploratory wells are being collected by the UGS. Well locations, production reports, completion tests, core analysis, formation tops, and other data were compiled and entered in a database developed by the UGS. This database, INTEGRAL*gim, is a geologic-information manager that links a diverse set of geologic data to records using $P A R A D O X^{T M}$ for DOS software. The database is designed so that geological information, such as lithology, porosity, or depositional environment, can be exported to software programs to produce strip logs, lithofacies maps, various graphs, statistical models, and other types of presentations. The UGS acquired information for 51 project wells. Production data, geophysical log types, and well cutting information for these project wells were entered into the UGS INTEGRAL* gim database. In addition, completion test data and formation tops were also entered for 33 of these wells into the database. The database containing information from the project will be available as a UGS open-file (digital format) report at the conclusion of Phase I, the geological and reservoir characterization study.

Base maps and new isochron maps covering project fields were prepared and cores were described from selected project wells with special emphasis on bounding surfaces of possible flow units. The core descriptions follow the guidelines of Bebout and Loucks (1984) which include: (1) basic porosity types, (2) mineral composition in percentage, (3) nature of contacts, (4) carbonate structures, (5) carbonate textures in percentage, (6) carbonate fabrics, (7) grain size (dolomite), (8) fractures, (9) color, (10) fossils, (11) cement, and (12) depositional environment. Carbonate fabrics were determined according to Dunham's (1962) and Embry and Klovan's (1971) classification schemes.

\subsection{Field Studies}

Geologic, reservoir, and production data for each project field are summarized in Appendix A. Oil and gas are produced from the Pennsylvanian (Desmoinesian) Desert Creek and Is̀may zones of the Paradox Formation. The fields were discovered in 1990 and 1991 as part of an ambitious exploration program conducted within the Navajo Nation by Chuska Energy Company (now Harken Southwest Corporation) and several Australian companies. Seismic surveys and subsurface geology were used to identify prospects. Each carbonate mound is expressed on seismic coverage (figure 3.1) by isochron thickening of the Desert Creek zone, isochron thinning of the overlying Ismay zone, amplitude dimming of the Desert Creek reflector, and a "doublet" development of the Desert Creek event (Johnson and Groen, 1993).

Each field consists of one to four wells. Development wells are drilled on either 40-acre (16ha) spacing or under the 80-acre-(32-ha-)spacing rules established at Greater Aneth field. Completion practices consist of selective perforation and treatment with varying amounts of acid. The reservoir drive is gas expansion. Primary production ranges from 700,000 to $2,000,000$ barrels (bbls $\left[111,300-318,000 \mathrm{~m}^{3}\right.$ ) of oil per field at a 15 to 20 percent recovery rate. Geological and engineering data for each field are summarized on table 3.2. 


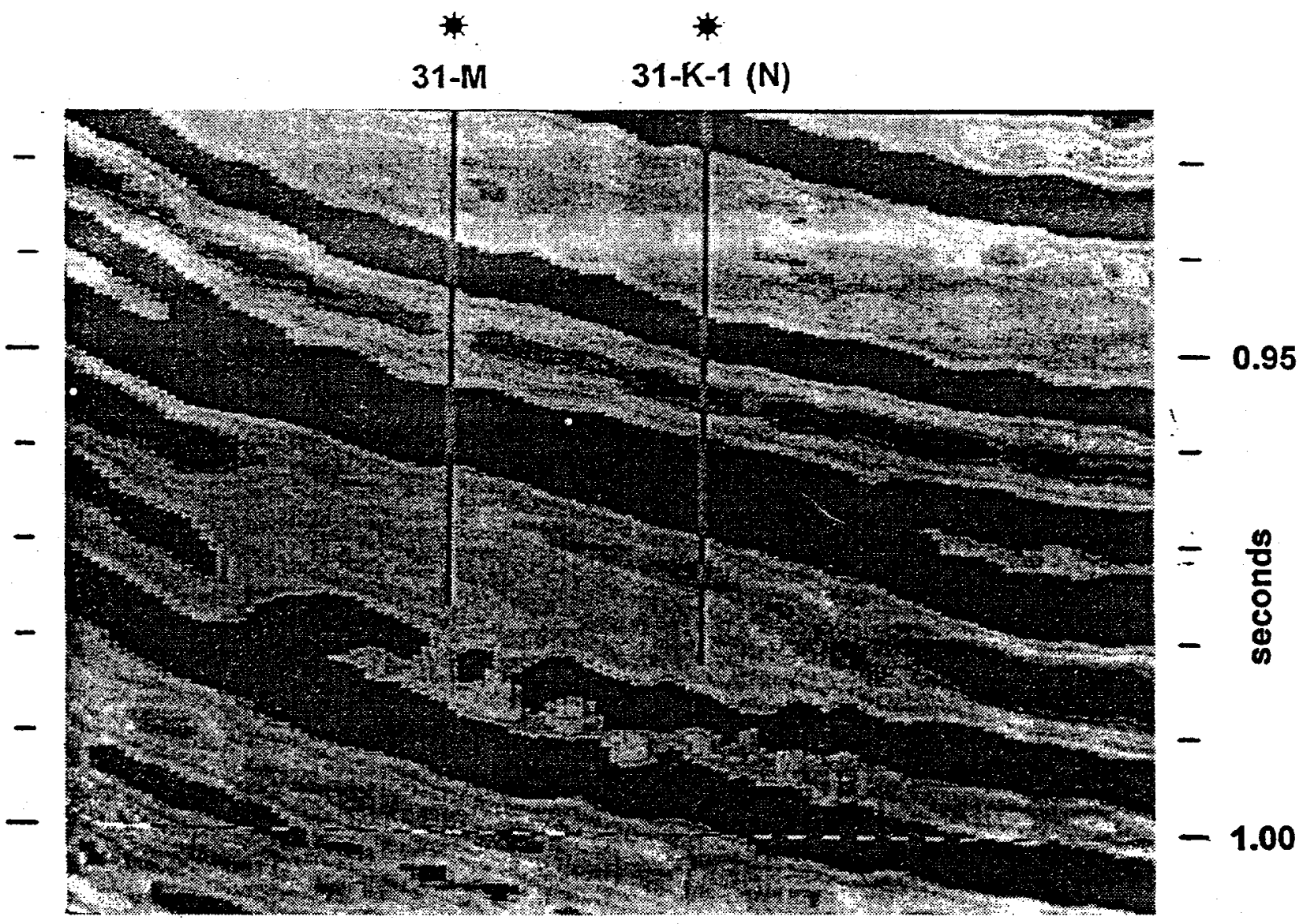

Figure 3.1. Representative seismic line, shaded according to amplitude variations, across Mule field. In general, the lighter the shades the more porous the reservoir rock within the carbonate buildup. The reservoir rock in the non-commercial Mule No. 31-K-1 (N) well is tight while the reservoir rock in the Mule No. 31-M well is more porous, resulting in excellent production. Both wells are located in section 31, T. 41 S., R. 24 E., Salt Lake Base Line, Navajo Nation, San Juan County, Utah.

Table 3.2. Geological and engineering data for project fields in the Paradox basin, San Juan County, Utah.

\begin{tabular}{|c|c|c|c|c|c|c|c|c|}
\hline 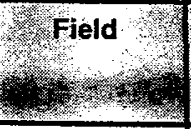 & Peptri) & 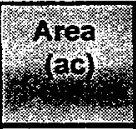 & 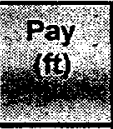 & $\begin{array}{l}\text { Porosity } \\
(\%)\end{array}$ & 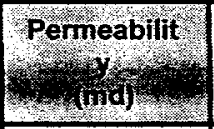 & $\begin{array}{l}\text { Water } \\
\text { saturatior } \\
\text { spop }\end{array}$ & 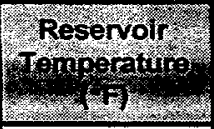 & 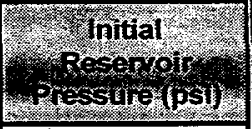 \\
\hline Runway & 5,896 & 193 & 72 & 11.8 & 10.0 & 25.2 & 126 & 2,162 \\
\hline Heron North & 5,584 & 110 & 60 & 15.0 & 17.7 & 32.2 & 126 & 1,934 \\
\hline Anasazi & 5,574 & 165 & 57 & 14.1 & 135.3 & 28.1 & 138 & 1,945 \\
\hline Mule & 5,655 & 48 & 47 & 13.0 & 20.1 & 31.0 & 128 & 2,050 \\
\hline Blue Hogan & 5,400 & 89 & 82 & 9.1 & 33.6 & 29.0 & 128 & 1,800 \\
\hline
\end{tabular}

*Average depth to the top of the reservoir. 


\subsubsection{Runway Field}

Runway field (figure 1.1) consists of three wells with the discovery well, the Runway No. 10-G-1, completed in 1990 at an initial potential flow (IPF) of 825 bbls of oil per day (BOPD [131 $\mathrm{m}^{3} / \mathrm{d}$ ) and 895 thousand cubic feet of gas per day (MCFGPD $\left[25,000 \mathrm{~m}^{3} / \mathrm{d}\right]$ ) from commingled Desert Creek and upper Ismay zones. The Runway prospect was identified as a high-resolution, common-depth point seismic anomaly in the northern Aneth platform area. This anomaly, east of the Greater Aneth field (figure 3.2), is located on the upthrown edge of a basement-involved, Mississippian-age normal fault which was a topographic high during Paradox Formation time.

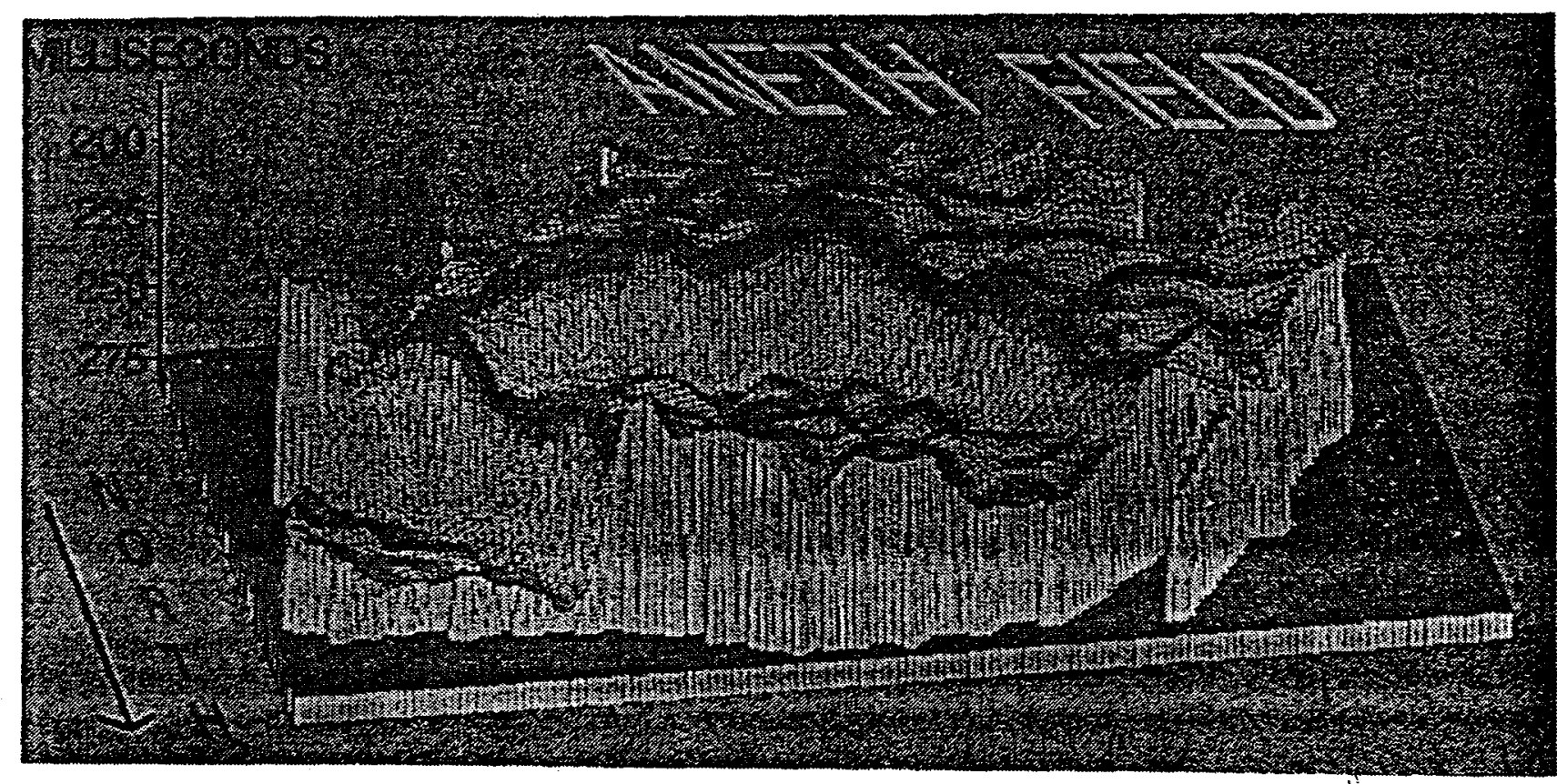

Figure 3.2. Three-dimensional "net" view to the southwest of the surface on top of the Mississippian Leadville Limestone and the north-bounding faults which control the localization of small algal and other carbonate buildups such as at the Runway field. This computerized presentation was produced from a closely spaced seismic grid.

The Runway field is a lenticular, west to east-northeast trending lobate mound, 0.9 miles ( 1.5 $\mathrm{km})$ long and 0.5 miles $(0.8 \mathrm{~km})$ wide. The reservoir consists of a bryozoan-dominated mound with phylloid algal mound intervals. The presence of two mound types at Runway field suggests that the water depth changed as the carbonate deposits built up over the fault-controlled paleohigh. The principal Desert Creek reservoir rocks in the field are bindstone and framestone, rarely dolomitized, in the bryozoan-dominated interval and porous bafflestone (calcified plates of the green algae Ivanovia) with some grainstone and occasional dolomitization in the phylloid algal mound interval. The Ismay reservoir rock is sucrosic dolomite. Both carbonate buildups are interbedded with low permeability wackestone and mudstone. 
The Runway field lies along a generally gas-rich trend east and north of Greater Aneth field. Cumulative production from Runway field is: 750,772 bbls of oil (BO [119,373 $\left.\mathrm{m}^{3}\right]$ ) and 2.27 billion cubic feet of gas (BCFG [0.06 billion $\left.\mathrm{m}^{3}\right]$ ) as of January 1, 1996 (Utah Division of Oil, Gas and Mining [DOGM], 1996). Estimated primary recovery is $800,000 \mathrm{BO}\left(127,200 \mathrm{~m}^{3}\right)$ and $2.99 \mathrm{BCFG}$ $\left(0.09\right.$ billion $\left.\mathrm{m}^{3}\right)$.

\subsubsection{Heron North}

Heron North field (figure 1.1), southeast of the Greater Aneth field, consists of one well, the North Heron No. 35-C, completed in 1991 at an IPF of 605 BOPD (96 m²/d) and $230 \mathrm{MCFGPD}$ $\left(6,500 \mathrm{~m}^{3} / \mathrm{d}\right)$ from the Desert Creek zone. The North Heron prospect was identified as a seismic anomaly.

The Heron North field is a lenticular, northwest to southeast trending linear mound/beach complex, 0.8 miles $(1.3 \mathrm{~km})$ long and 0.5 miles $(0.8 \mathrm{~km})$ wide. The reservoir consists of a bioclastic calcarenite mound above a anhydrite- and salt-plugged phylloid algal mound. This calcarenite mound type, which is also productive in the Heron $35-\mathrm{H}$ well 0.5 miles $(0.8 \mathrm{~km})$ southeast of Heron North, developed in a carbonate beach to foreshore environment with moderately high wave energy. Trough cross-bedding is often present. The reservoir consists of alternating 2- to 4-ft-(0.6-1.2-m)thick packages of uniform beach calcarenite and poorly sorted foreshore and storm lag rudstone or breccia deposits. An 8-ft-(2.4-m-)thick anhydrite lies immediately above the reservoir interval and creates an effective seal. The principal reservoir rocks in the field are porous, sucrosic, dolomitized grainstone and packstone (calcarenite) above tight bafflestone composed of algal stromatolithic mats. The calcarenite and bafflestone intervals are separated by low permeability, dolomitized wackestone and mudstone. Stylolitization, secondary cementation, and evaporite plugging are modest in the upper portion of the reservoir, but increase with depth. Pores are often lined with bitumen which in many instances plugs pore throats.

Cumulative production from Heron North field is $200,759 \mathrm{BO}\left(31,921 \mathrm{~m}^{3}\right)$ and $0.31 \mathrm{BCFG}$ $\left(0.009\right.$ billion $\left.\mathrm{m}^{3}\right)$ as of January 1,1996 (DOGM, 1996). Estimated primary recovery is $990,000 \mathrm{BO}$ $\left(157,410 \mathrm{~m}^{3}\right)$ and $2.65 \mathrm{BCFG}\left(0.08\right.$ billion $\left.\mathrm{m}^{3}\right)$.

\subsubsection{Mule Field}

Mule field (figure 1.1) consists of two wells, the Mule No. 31-K-1 $(\mathrm{N})$ discovery well and the Mule No. 31-M well, completed in 1991 and 1992 respectively. The Mule No. 31-K-1 (N) well tested approximately $10 \mathrm{bbls}\left(1.6 \mathrm{~m}^{3}\right)$ of oil per hour (based on several swab tests) with water cut increasing on each test and produced only $283 \mathrm{BO}\left(45 \mathrm{~m}^{3}\right)$ before being shut-in. The Mule No. 31-M offset well had an IPF of 735 BOPD $\left(117 \mathrm{~m}^{3} / \mathrm{d}\right)$ and $97 \mathrm{MCFGPD}\left(3,000 \mathrm{~m}^{3} / \mathrm{d}\right)$ from the Desert Creek zone. The Mule prospect, near the southwestern edge of the Greater Aneth field, was identified as a seismic anomaly (figure 3.1). A seismic program was laid out for the field, and new seismic interpretations and mapping commenced.

The Mule field is a lenticular, northeast to east trending linear mound/mound flank deposit, 0.5 miles $(0.8 \mathrm{~km})$ long and 900 feet $(274 \mathrm{~m})$ wide. The reservoir consists of a phylloid algal mound combined with mound flank detrital deposits. This mound type, which dominates the area southwest of Greater Aneth field, developed where shallow water depth and low wave energy allowed establishment of phylloid algal colonies on paleohighs. Several beds in the Mule 31-K-1 (N) well core exhibit characteristics of mound flank deposits such as downslope gravity transport and sharp 
erosional basal contacts. The top of the phylloid algal interval is highly irregular with several crosscutting zones of dissolution cavities possibly from karst development during subaerial exposure. The principal reservoir rock in the field is porous algal bafflestone (figure 3.3), crinoidal packstone, and dolomitized zones interbedded with low permeable wackestone, mudstone, and dolomite. Incomplete dolomitization and secondary anhydrite replacement have resulted in poor reservoir properties in some intervals.

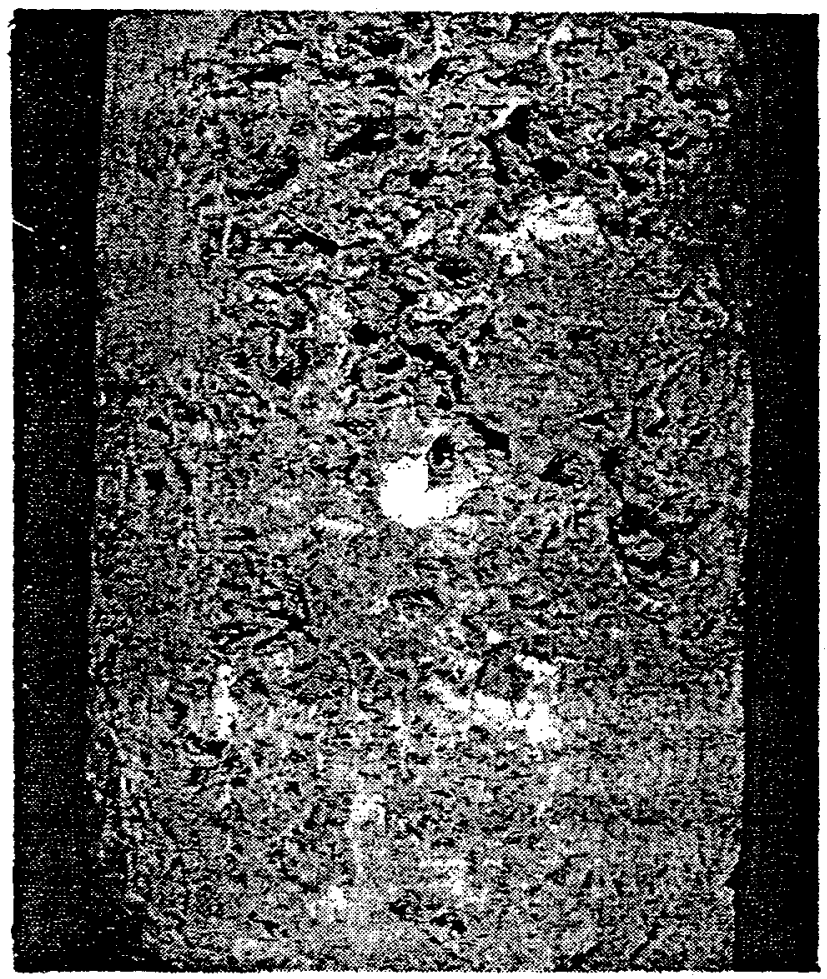

Figure 3.3. Core surface view of highly productive, dolomitized, phylloidal algal plate bafflestone from the Mule No. 31-M well, Mule field (see figure 3.1 for seismic line through well). Note good visual shelter porosity. Core diameter $=3.5$ inches $(8.9 \mathrm{~cm})$.

Cumulative production from Mule field is $343,180 \mathrm{BO}\left(54,566 \mathrm{~m}^{3}\right)$ and $0.2 \mathrm{BCFG}(0.006$ billion $\mathrm{m}^{3}$ ) as of January 1,1996 (DOGM, 1996). Estimated primary recovery is $430,603 \mathrm{BO}$ $\left(68,466 \mathrm{~m}^{3}\right)$ and $0.288 \mathrm{BCFG}\left(0.008\right.$ billion $\left.\mathrm{m}^{3}\right)$.

\subsubsection{Blue Hogan}

Blue Hogan field (figure 1.1) consists of one well, the Blue Hogan No. 1-J-1, completed in 1991 at an IPF of 1,167 BOPD $\left(186 \mathrm{~m}^{3} / \mathrm{d}\right)$ and 722 MCFGPD $\left(20,447 \mathrm{~m}^{3} / \mathrm{d}\right)$ from the Desert Creek zone. The Blue Hogan prospect, near the southwest edge of the Greater Aneth field, was identified as a seismic anomaly along the east flank of the Desert Creek anticline. 
Blue Hogan field is a lenticular, northwest to southeast trending linear mound, 0.5 miles ( 0.8 $\mathrm{km})$ long and 1,000 feet $(305 \mathrm{~m})$ wide. The reservoir consists of a cement-rich phylloid algal mound. The principal reservoir rock in the field is porous algal bafflestone and dolomitized zones interbedded with low permeability wackestone and mudstone.

Cumulative production from Blue Hogan field is $282,718 \mathrm{BO}\left(44,952 \mathrm{~m}^{3}\right)$ and $0.26 \mathrm{BCFG}$ $\left(0.007\right.$ billion $\mathrm{m}^{3}$ ) as of January 1, 1996 (DOGM, 1996). Estimated primary recovery is $645,000 \mathrm{BO}$ $\left(102,555 \mathrm{~m}^{3}\right)$ and $0.968 \mathrm{BCFG}\left(0.03\right.$ billion $\left.\mathrm{m}^{3}\right)$.

\subsubsection{Anasazi Field}

Anasazi field (figure 1.1) consists of four wells. The discovery well, the Anasazi No. 1, was completed in 1990 at an IPF of 1,705 BOPD $\left(271 \mathrm{~m}^{3} / \mathrm{d}\right)$ and 833 MCFGPD $\left(23,591 \mathrm{~m}^{3} / \mathrm{d}\right)$ from the Desert Creek zone. The Anasazi prospect, near the southwest edge of Greater Aneth field, was identified as a seismic anomaly along the east flank of the Desert Creek anticline. A modified seismic interpretation was completed for the field and converted into a gross Desert Creek isopach map to evaluate the area for additional drilling.

Anasazi field is a lenticular, west to northeast trending lobate mound, 0.9 miles $(1.5 \mathrm{~km})$ long and 2,000 to 3,000 feet $(610-914 \mathrm{~m})$ wide. The reservoir consists of a phylloid algal mound. The principal reservoir rock in the field is porous algal bafflestone, some grainstone, and dolomitized zones interbedded with low permeable wackestone and mudstone. Extensive fresh water dissolution and early dolomitization has resulted in good to excellent porosity development and permeability modification.

Cumulative production from Anasazi field is 1,650,133 BO $\left(262,371 \mathrm{~m}^{3}\right)$ and $1.28 \mathrm{BCFG}$ $\left(0.04\right.$ billion $\left.\mathrm{m}^{3}\right)$ as of January 1,1996 (DOGM, 1996). Estimated primary recovery is 2,069,392 BO $\left(329,033 \mathrm{~m}^{3}\right)$ and $1.89 \mathrm{BCFG}\left(0.05\right.$ billion $\left.\mathrm{m}^{3}\right)$. Preliminary analysis of Anasazi field indicates the Desert Creek reservoir is a prime candidate for a waterflood or $\mathrm{CO}_{2}$ miscible flood demonstration.

\subsection{New Development Wells}

\subsubsection{Drilling Rationale}

A team of geologists, reservoir engineers, and geophysicists from Harken evaluated potential development locations for the project fields. Project development wells are designed to increase the well density from 80 acres ( $32.3 \mathrm{ha}$ ) per well to 30 to 40 acres (12-16 ha) per well. During the first project year, one development well was drilled in the Anasazi field and permitting began for a second well, a horizontal lateral from the Mule No. 31-K-1 (N) well in Mule field. The length and orientation of the lateral will be determined upon completion and evaluation of the new seismic data.

The data obtained from these new wells will enable the project team to assess: (1) the frequency of reservoir compartments (reservoir heterogeneity) in a given area, (2) the amount of communication between compartments, (3) how a waterflood or $\mathrm{CO}_{2}$ flood will move from one compartment to another, and (4) the areal extent of an average compartment. The following new well information will be used in the geologic and reservoir characterization:

1. more accurate descriptions of the general reservoir geology and reservoir compartmentalization/continuity, 
2. pressure data in drawn down areas from current producers,

3. wettability and relative permeability data from fresh cores,

4. pressure transient data to determine communication with other fields (determine communication with adjacent reservoirs previously thought separate), and

5. increased data for the reservoir simulation history match to allow for better construction of models used in $\mathrm{CO}_{2}$ /water flow simulations.

\subsubsection{Anasazi No. 6H-1 Well, Anasazi Field}

The first project development well, the Anasazi No. 6H-1, was spudded on May 20, 1995 and drilled to a total depth of 5,826 feet $(1,776 \mathrm{~m})$ in the Anasazi field, SE1/4NE1/4 section 6, T. $42 \mathrm{~S}$., R. 24 E., Salt Lake Base Line, Navajo Nation, San Juan County, Utah (figure 3.4). The principal reservoir evaluated, a carbonate buildup in the Desert Creek zone of the Paradox Formation, was penetrated at 5,624 feet $(1,714 \mathrm{~m})$. The buildup was cored $(120$ feet [ $37 \mathrm{~m}$ ] of conventional core recovered) and described. Geophysical logs run consisted of the dual laterolog, spectral density, dual-spaced neutron, gamma ray, and long-spaced sonic. The wireline formation tester obtained reservoir pressures throughout the Desert Creek zone ranging from 300 to 1,200 pounds per square inch (psi [2,069-8,274 kpa]). The main pay intervals held 15 to 25 percent of the original reservoir pressure.

The Anasazi No. 6H-1 well was completed on September 15, 1995 for an IPF of 31.3 BOPD $\left(5.0 \mathrm{~m}^{3} / \mathrm{d}\right), 25 \mathrm{MCFGPD}\left(708 \mathrm{~m}^{3} / \mathrm{d}\right)$, and $7.5 \mathrm{bbls}\left(1.2 \mathrm{~m}^{3}\right)$ of water per day in the Desert Creek and Ismay zones. A grainstone/packstone interval in the Desert Creek zone was perforated from 5,723 to 5,730 feet $(1,744-1,746 \mathrm{~m}$ ) and acidized with 350 gallons (gal [1,325 L]) of 15 percent hydrochloric acid (HCL). The resulting test indicated the pressure and permeability in the interval were too low to yield any meaningful data. A dolomite interval in the upper section of the Desert Creek was perforated from 5,680 to 5,694 feet $(1,731-1,735 \mathrm{~m})$. This interval was subsequently acidized with $30 \mathrm{gal}(114 \mathrm{~L})$ of HCL and swab tested for 2 BOPD $\left(0.3 \mathrm{~m}^{3} / \mathrm{d}\right)$. After the swab test, a 200 hour pressure buildup test was run. A skin factor and permeability of +13 and 1.2 millidarcies (md) respectively was derived from the pressure buildup test. Given the high skin damage, the zone was re-acidized. Several additional intervals were perforated and acidized including the upper Ismay zone from 5,526 to 5,531 feet $(1,684-1,686 \mathrm{~m})$. Production facilities were installed and the well flow rate stabilized at 17 BOPD $\left(3 \mathrm{~m}^{3} / \mathrm{d}\right)$ from a gross perforated Desert Creek interval of 5,664 to 5,741 feet $(1,726-1,750 \mathrm{~m})$ and a Ismay interval of 5,526 to 5,531 feet $(1,684-1,686 \mathrm{~m})$.

Conventional core was obtained from the Desert Creek zone of the Anasazi $6 \mathrm{H}-1$ well. Evaluation of the core suggests the well missed the main buildup or mound core interval (algal bafflestone reservoir) and penetrated poorer quality mound flank deposits (mixed carbonate fabrics that are brecciated; slumped, and chaotic) instead. However, the dolomites in the upper part of the buildup or supra-mound may be connected to the upper Anasazi reservoirs in the rest of the field.

Selected plugs from the reservoir were used to determine oil/water and gas/oil relative permeability measurements (see section 5., Engineering Reservoir Characterization of the Carbonate Reservoir in the Desert Creek Zone). These data will be incorporated into the Anasazi reservoir flow simulation model. Whole core intervals were scanned using computerized axial tomography (CAT) techniques to ensure that permeability measurements are based on comparable pore systems. The 


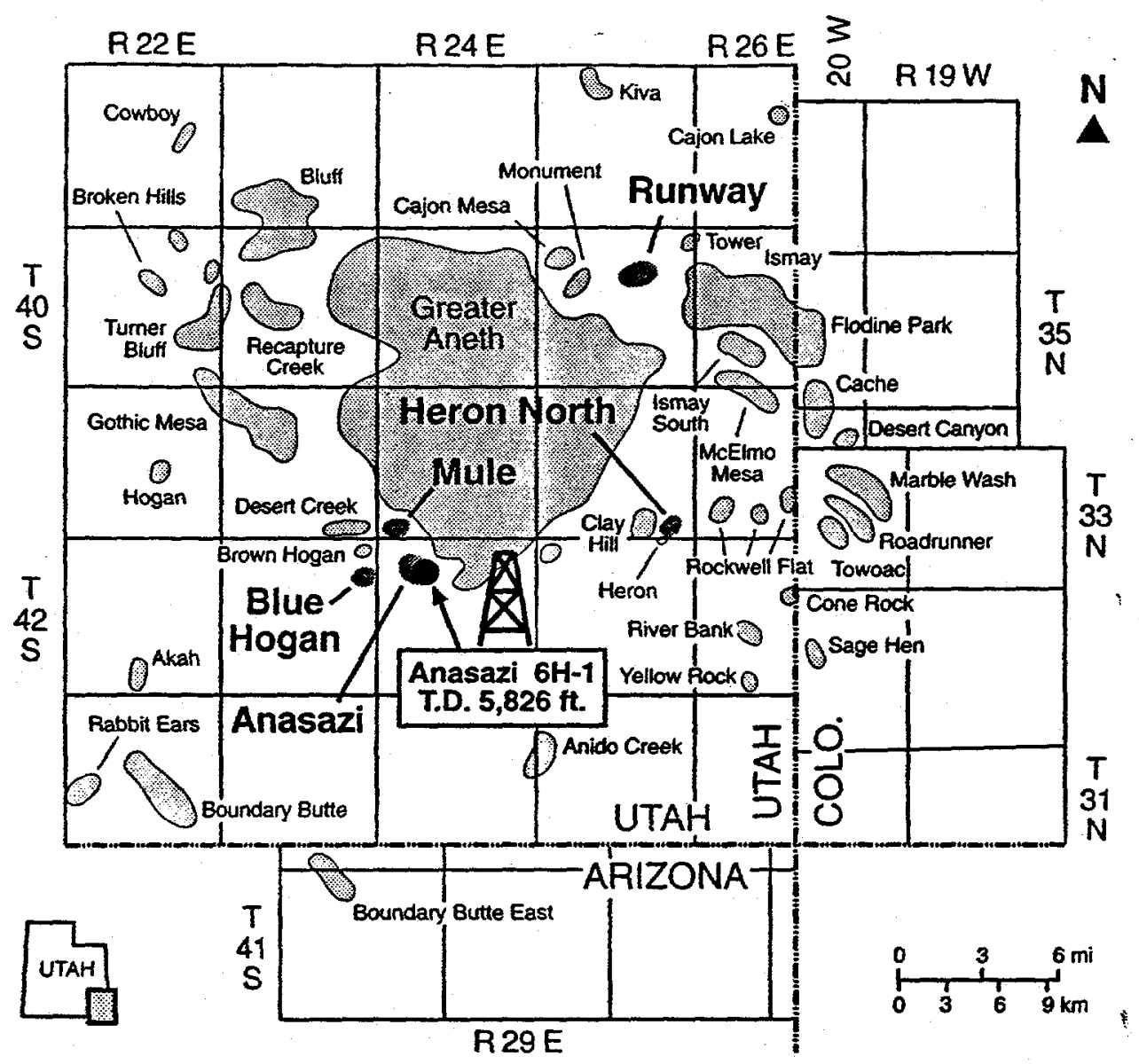

Figure 3.4. Location of the first project development well, the Anasazi No. 6H-1, drilled in the Anasazi field, SE1/4NE1/4 section 6, T. 42 S., R. 24 E., Salt Lake Base Line, Navajo Nation, San Juan County, Utah.

three most homogeneous intervals were selected for additional analysis. Upon further examination and CAT scans, one interval appeared as the most homogeneous and contained the highest porosity. Four transverse plugs were taken from this interval for detailed CAT scans, and porosity and relative permeability measurements (figure 3.5). A variety of features were observed using these techniques including anhydrite-filled vugs, both micro-vuggy and intercrystalline porosity, patches of bitumenfilled pores, and areas of nonporous carbonate mudstone.

The pressure buildup tests are being used to determine average reservoir pressure, boundaries, and flow properties. Fluid samples taken from these intervals were used for extensive compositional studies. 


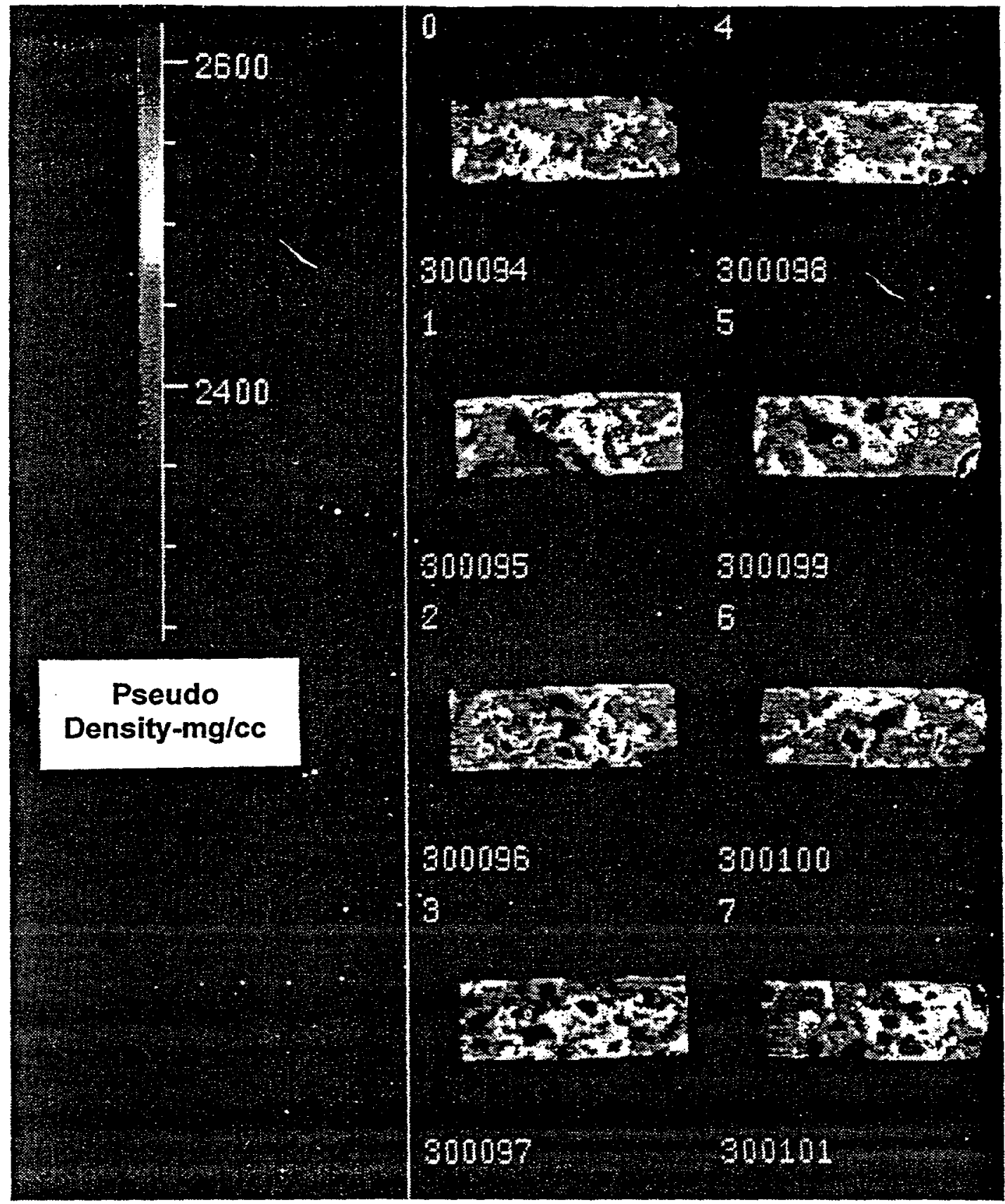

Figure 3.5. A set of CAT scans of two mutually perpendicular longitudinal-axial sections of each of the four core plugs taken from the Anasazi No. 6H-1 well to assess heterogeneity and select the most consistent intervals for measuring porosity and relative permeability in the Anasazi reservoir. 


\subsection{References}

Dunham, R.J., 1962, Classification of carbonate rocks according to depositional texture, in Ham, W.E., editor, Classification of carbonate rocks: American Association of Petroleum Geologists Memoir 1, p. 108-121.

Eby, D.E., Groen, W.G., and Johnson, J.F., 1993, Composition of seismically identified satellite mounds surrounding Greater Aneth field, southeast Utah (abs.): American Association of Petroleum Geologists Bulletin, v. 77, no. 8: p. 1446-1447.

Embry, A.R., and Klovan, J.E., 1971, A Late Devonian reef tract on northeastern Banks Island, Northwest Territories: Canadian Petroleum Geologists Bulletin, v. 19, p. 730-781.

Johnson, J.F., and Groen, W.G., 1993, Seismic structure and seismic stratigraphy of the giant Aneth field and its satellite fieids of southeast Utah (abs.): American Association of Petroleum Geologists Bulletin, v. 77, no. 8, p. 1452-1453.

Utah Division of Oil, Gas and Mining, 1996, Oil and gas production report, December 1995: nonpaginated. 


\title{
4. GEOLOGICAL CHARACTERIZATION OF THE CARBONATE RESERVOIR IN THE DESERT CREEK ZONE
}

\author{
Douglas M. Lorenz \\ REGA Inc.
}

\subsection{Location, Geometry, and General Stratigraphy}

Of the five carbonate buildup fields in the Desert Creek zone originally identified as candidates for detailed study, the Anasazi field was selected for the initial investigation (figure 1.1). This mound complex has the longest production history (greater than six years) and largest amount of hard data for reservoir characterization (four logged wells, three of which are also cored through the Desert Creek zone), has the most seismic coverage (six two-dimensional lines), and was considered the most promising candidate for enhanced recovery.

A detailed carbonate isolith map of the Desert Creek zone in the Anasazi area (figure 4.1) shows two mound buildups of more than 60 feet $(18 \mathrm{~m})$, based on well $\log$ and seismic information. Three peripheral dry holes (Navajo No. 4-D [section 5, T. 42 S., R. 24 E., Salt Lake Base Line], Navajo No. D-1 [section 6, T. 42 S., R. 24 E., Salt Lake Base Line], and Navajo No. B-7 [section 32, T. 41 S., R. 24 E., Salt Lake Base Line]) do not penetrate any mound buildup facies in the Desert Creek zone, and serve to define the average non-mound thickness $(110$ feet [ $34 \mathrm{~m}])$ in the vicinity of the Anasazi field.

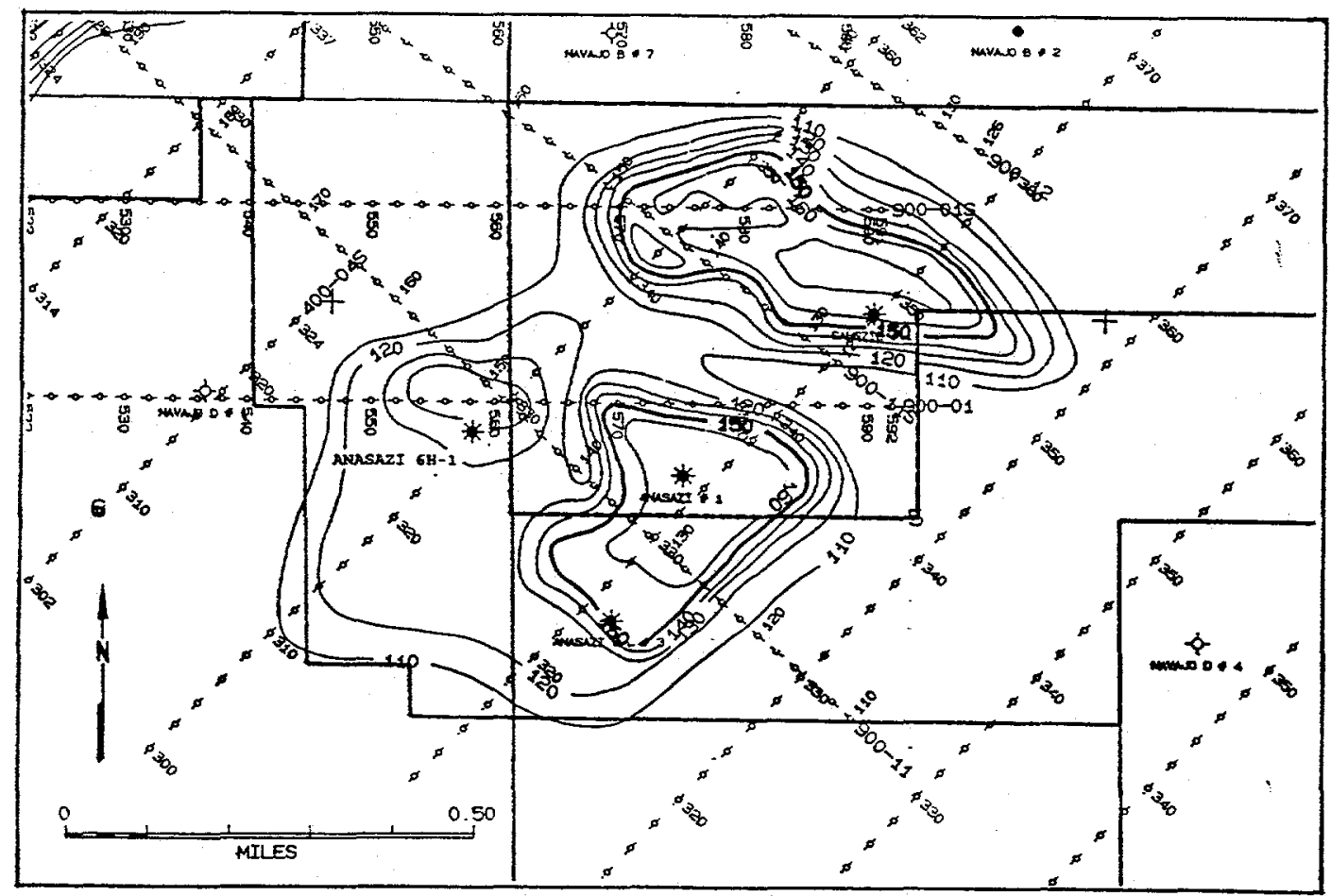

Figure 4.1. Gross Desert Creek isopach based on geophysical well log and seismic data, Anasazi field, sections 5 and 6, T. 42 S., R. 24 E., Salt Lake Base Line, San Juan County, Utah. Contour interval $=\mathbf{1 0}$ feet. 
A variety of carbonate facies is encountered in all four Anasazi wells which exhibit a high degree of spatial heterogeneity in reservoir properties. To adequately represent the effects of this heterogeneity on reservoir behavior, detailed characterizations of these heterogeneous facies and their joint distributions within the reservoir volume must be developed.

In the mound buildup area, the Desert Creek zone is stratigraphically subdivided into three intervals. The lowest interval, averaging 25 feet $(8 \mathrm{~m})$ in thickness, consists largely of tight dolomudstones, with some slightly enhanced porosity (up to 10 percent) and interbedded dolomitized packstones and wackestones. A middle interval or mound core (30 to 50 feet [9-15 m] thick) is comprised almost entirely of phylloid algal bafflestone. These mound-building limestones exhibit substantial porosity (up to 22 percent locally) and permeability (generally 150 to $300 \mathrm{md}$; locally greater than $1,000 \mathrm{md})$. The upper interval (55 to 65 feet [17-20 m] thick) contains largely dolomitized mudstones, packstones, wackestones, and grainstones in which each lithotype shows a wide range of secondary pore system alteration from slight (porosity less than 2 percent, permeability less than $0.1 \mathrm{md}$ ) to significant (porosity greater than 24 percent, permeability up to 50 md). Based on detailed core and log interpretations of the Anasazi wells and on geological studies of nearby analogous Pennsylvanian carbonate mound buildups (see section 2.2, Outcrop Reservoir Analogues), these three successive stratigraphic intervals are identified as distinct time-equivalent sequences, termed the "platform interval", the "mound-core interval" and the "supra-mound interval", respectively. Detailed correlation of flooding surfaces (figure 4.2) demonstrates their lateral continuity within the Anasazi mound complex. The mound-core and supra-mound intervals together constitute the Anasazi reservoir; the platform interval is tight and does not yield commercial hydrocarbons.

\subsection{Reservoir Architecture}

The Anasazi reservoir is stratigraphically divisible into two distinctly different intervals: (1) the lower mound-core interval, consisting primarily of a thick, porous and highly permeable phylloid algal bafflestone in the mound buildup area itself, and thin dolomudstones, packstones, wackestones, and a few grainstones in flanking peripheral areas; and (2) the overlying supra-mound interval, a sequence of heterogeneous dolomites (mudstones, packstones, wackestones, and grainstones) with lower permeability and higher average porosity than the underlying algal bafflestones. Results of simple two-layer constant-property, two-dimensional numerical flow simulations (see section 6 ., Mechanistic Reservoir Simulation Studies) indicate that although oil production rates are significantly higher in the permeable algal bafflestone of the mound-core interval, most of the oil resides in the overlying porous dolomites of the supra-mound interval. The results of these preliminary studies, along with field production data, show that as the oil is produced from the algal bafflestones, oil from the overlying dolomites continually replenishes the bafflestone pore system, resulting in a production capacity far greater than can be attributed to the mound-core interval alone. In addition, drilling history in the Anasazi field strongly suggests that the entire reservoir has been on pressure decline since the first well was drilled in 1989 (see Appendix A, Anasazi field summary). Thus, despite the apparent heterogeneity in reservoir properties, the mound-core interval bafflestones and the supra-mound interval dolomites apparently are in pressure communication throughout the reservoir. 


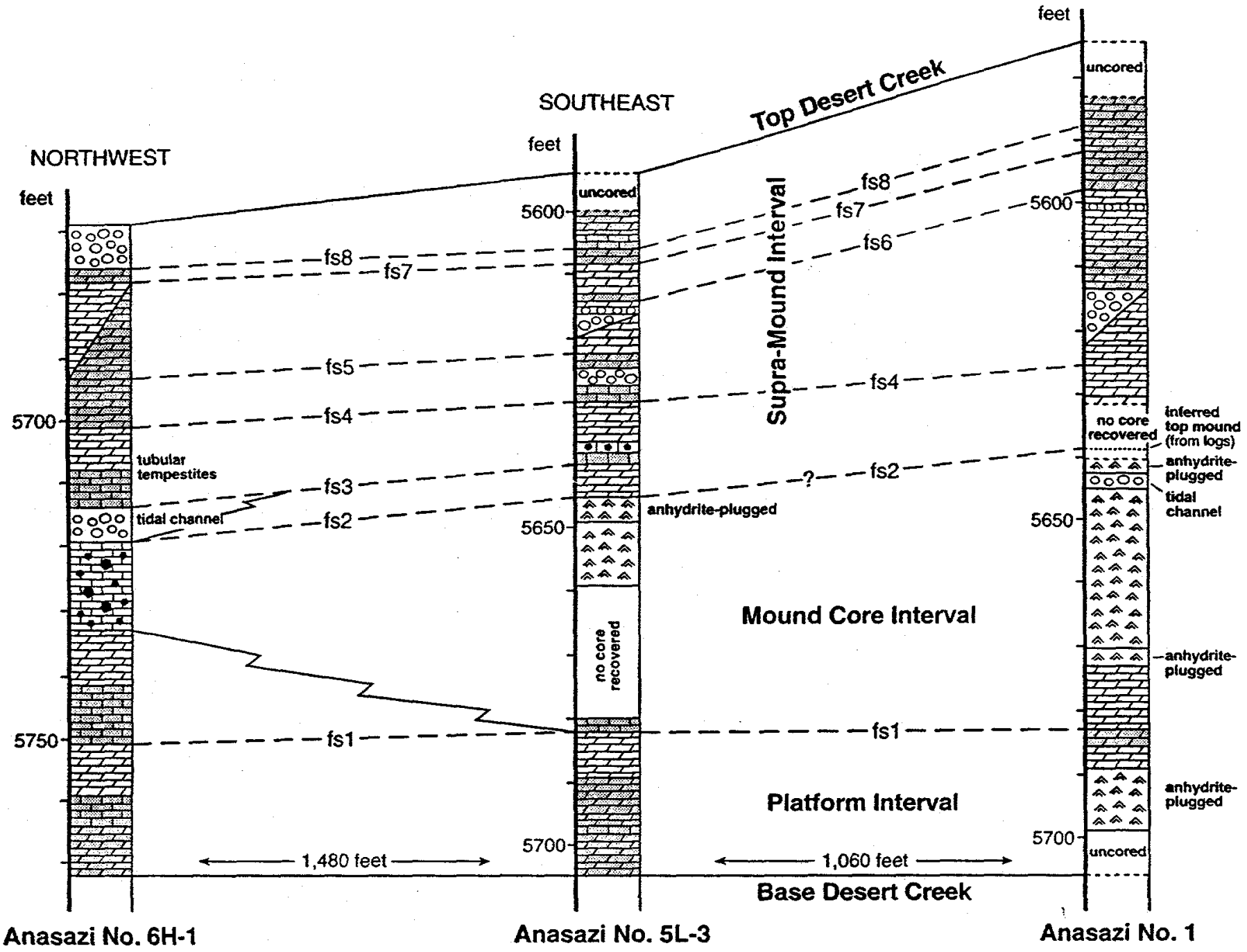

\section{EXPLANATION}

. Mound core phylloid algal bafflestone with fair to good porosity and excellent permeability (except near mound top where anhydrite plugging is common)- excellent reservoir quality

$\because 00$ Grainstones with enhanced porositygood to excellent reservoir quality

Dolomitized mudstones/packstones/wackestones with enhanced porosity- fair to good reservoir quality

Mound-flank mixed carbonates, brecciated/slumped/chaotic with fair porosity and permeability- fair reservoir quality

Tight mudstones/packstones/wackestones and cemented grainstones- poor reservoir quality

-

Figure 4.2. Stratigraphic cross section across Anasazi field displaying reservoir lithotypes, flooding surfaces, and facies relations within the Desert Creek platform, mound-core, and supra-mound intervals based on core. 
To represent the vertical and lateral heterogeneity known to be present in the Anasazi reservoir, yet ensure that the well-documented lateral and vertical communication also is realistically modeled, a detailed facies interpretation of the conventional core from three Anasazi wells (Anasazi Nos. 1, 5L-3, and 6H-1) was undertaken. From these results, together with the log interpretations (figure 4.3), conventional core analysis, and geologically inferred lateral facies relationships based on the outcrop studies, a reservoir modeling procedure was designed to incorporate the major facies types as individual architectural entities, each exhibiting internal heterogeneities in reservoir properties but contrasting sharply between the individual lithotypes. Ten architecturally distinct lithotypes were identified in the mound core interval, eight of which also comprise the supra-mound interval in the Anasazi reservoir (table 4.1). They include the tight mudstones, packstones, wackestones, and grainstones characteristic of the off-mound areas in both intervals (figure 4.4); similar facies exhibiting enhanced porosity resulting from dolomitization and/or leaching found in the buildup areas of the supra-mound interval (and also scattered throughout off-mound areas; figures 4.5 and 4.6 ); and the porous, highly permeable phylloid algal bafflestones and associated mound-flank breccias (figure 4.7) which are almost entirely restricted to the buildup areas of the mound-core interval.

\subsection{Reservoir Model Geometry}

The overall Desert Creek zone in the Anasazi field represented by the isopach in figure 4.1 includes not only the reservoir interval, but also: (1) the underlying non-reservoir platform interval and (2) a sequence of overlying anhydrites. However, the aggregate non-reservoir thickness in all four Anasazi wells is remarkably constant, measuring within two feet $(0.6 \mathrm{~m})$ of the average thickness of 62 feet $(19 \mathrm{~m})$. Consequently, an isolith map of the reservoir (mound-core plus supra-mound) intervals can be obtained (figure 4.8 ) by subtracting 62 feet $(19 \mathrm{~m})$ from the Desert Creek isopach. This isolith map is used in the model to define the upper boundary of the Anasazi reservoir. The base of the reservoir ( $=$ top of the platform interval) is approximately co-planar in the four Anasazi wells, and is represented in the model as a surface of uniform slope, dipping at $0.7^{\circ}$ to the southeast. Figure 4.8 also shows the $x-y$ map grid defined in the model, which consists of a 30 $X 50$ grid block array, with individual block dimensions of 105 feet $(32 \mathrm{~m})$ square.

Based on the observed bedding frequencies, an average layer thickness of two feet $(0.6 \mathrm{~m})$ in the mound buildup areas was selected for the initial reservoir model. Although the total reservoir thickness varies considerably (figure 4.8), the relative proportions of mound-core and supra-mound interval thicknesses in the four Anasazi wells are all about 0.4 and 0.6 , respectively (figure 4.3). Thus, the mound-core and supra-mound intervals are subdivided into 20 and 30 equal-thickness layers, which yield approximately two-foot $(0.6-\mathrm{m})$ layers within and over the mound buildups, thinning to about half that in the peripheral areas. Consequently, the initial Anasazi model consists of 50 layers, each divided geographically into 1,500 x-y blocks, for a total of 75,000 grid blocks, representing an overall volume of 57.8 million cubic feet $\left(17.6\right.$ million $\left.\mathrm{m}^{3}\right)$.

\subsection{Seismic Constraints}

One of the most difficult problems normally encountered in reservoir characterization is the lack of adequate data on patterns of lateral variation in reservoir properties between wells. Lacking hard data from horizontal wells or detailed three-dimensional seismic records, the only recourse is 

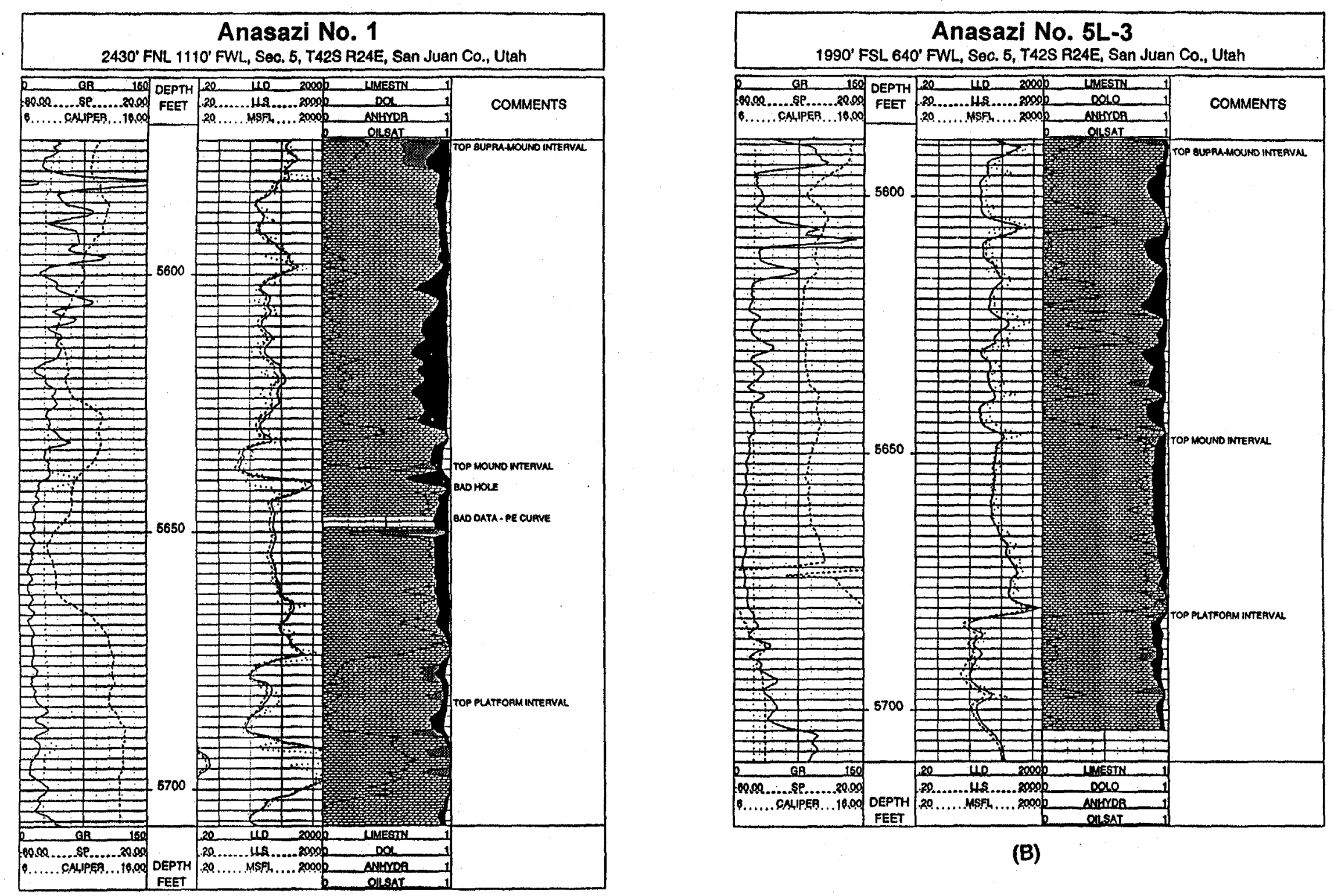

(A)

Figure 4.3. Computed geophysical well logs and lithology plots of the Desert Creek zone for the: (A) Anasazi No. 1, (B) Anasazi No. 5L-3, (C) Anasazi No. 6H-1, and (D) Sahgzie No. 1 wells, Anasazi field. 


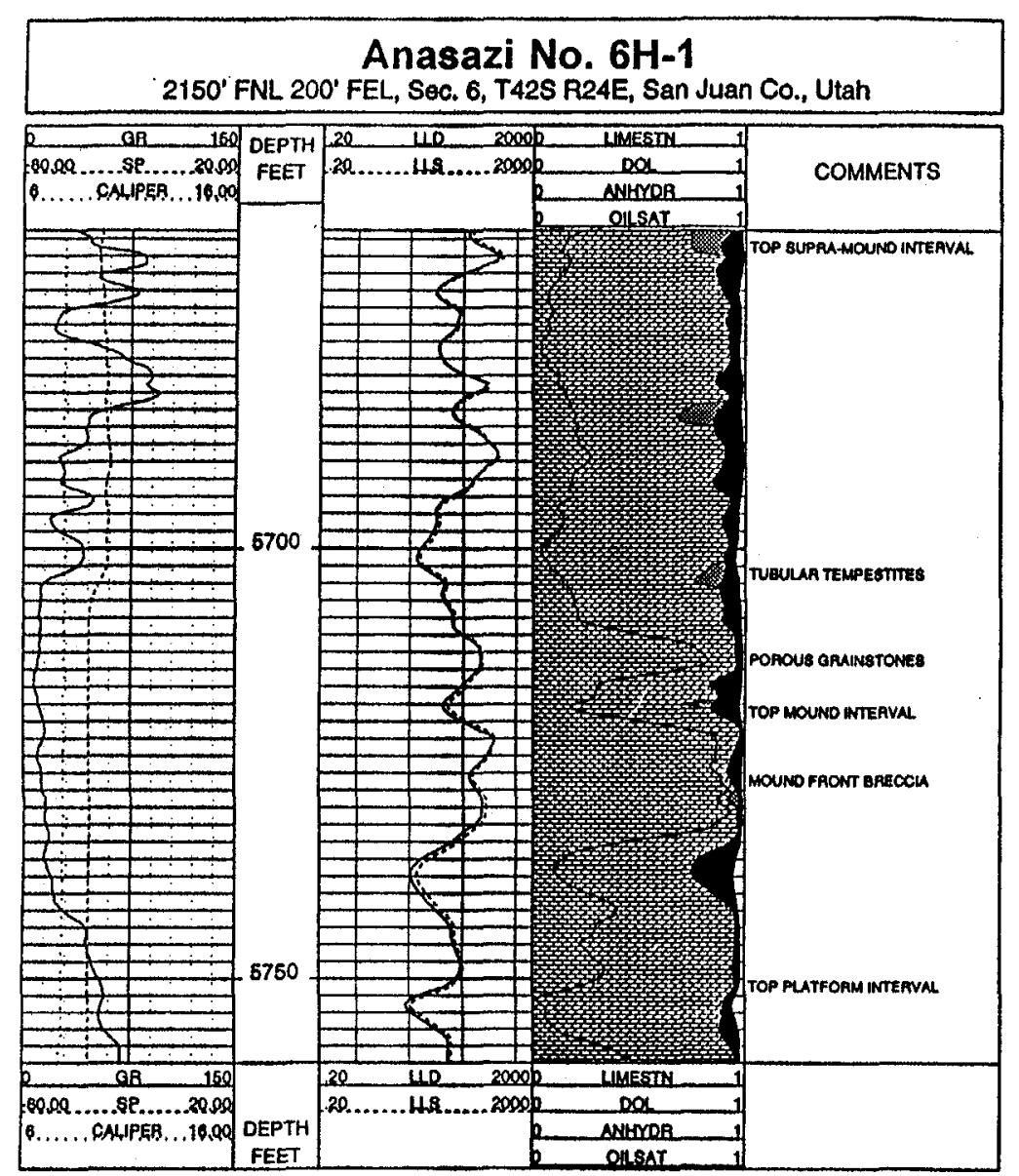

(C)
Sahgzie No. 1

1315' FNL 2340' FWL, Sec. 5, T42S R24E, San Juan Co., Utah

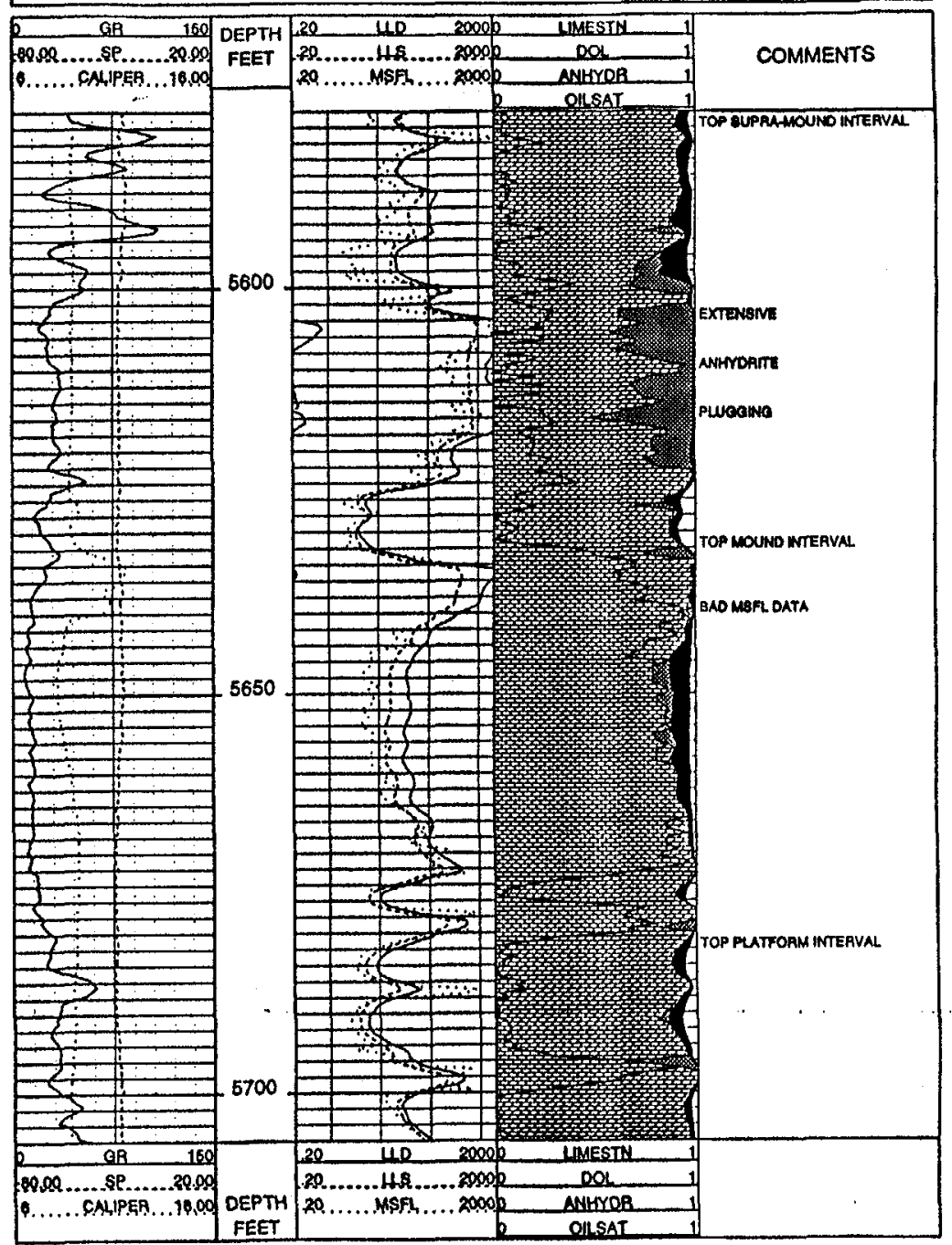

(D)

Figure 4.3. (continued). 
Table 4.1. Average reservoir properties of architectural lithotypes, Anasazi field.

\begin{tabular}{|c|c|c|c|c|}
\hline (3) & $\begin{array}{l}\text { Average Bed } \\
\text { Thickness } \\
\text { (ft) }\end{array}$ & $\begin{array}{l}\text { Average } \\
\text { Porosing } \\
(1 \%)\end{array}$ & $\begin{array}{l}\text { Average } \\
\text { Permeability } \\
\text { (md) }\end{array}$ & $\begin{array}{l}\text { Yolume } \\
\text { proportion }\end{array}$ \\
\hline Tight Mudstone & 3.7 & 2 & 0.25 & 0.24 \\
\hline Dolomitized Mudstone & 5.5 & 9 & 1.51 & 0.06 \\
\hline Porous Mudstone & 2.9 & 11 & 2.00 & 0.05 \\
\hline Tight Packstone/Wackestone & 2.4 & 2 & 0.02 & 0.14 \\
\hline Porous PackstoneMackestone & 3.8 & 10 & 1.80 & 0.05 \\
\hline Tight Grainstone & 2.2 & 2 & 0.15 & 0.07 \\
\hline Porous Grainstone & 3.2 & 15 & 15.00 & 0.08 \\
\hline $\begin{array}{l}\text { Tubular Tempestites in } \\
\text { Mudstone/Wackestone/Packstone }\end{array}$ & 6.7 & 9 & $\begin{array}{l}8.00 \\
\text { (est) }\end{array}$ & 0.07 \\
\hline Phylloid Algal Bafflestone & 42.0 & 10 & 150.00 & 0.22 \\
\hline Mound-Flank Breccia & 13.0 & 8 & $\begin{array}{l}30.00 \\
\text { (est) }\end{array}$ & 0.02 \\
\hline
\end{tabular}




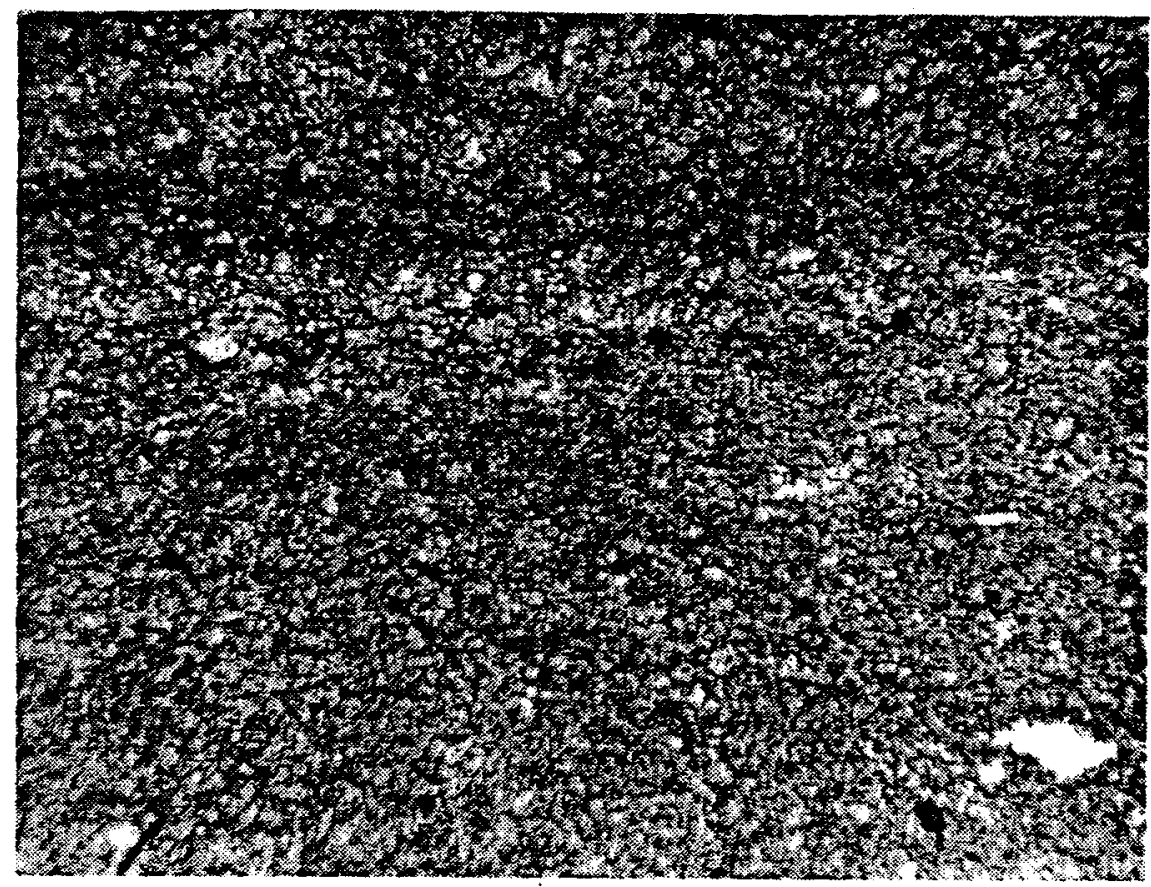

(A)

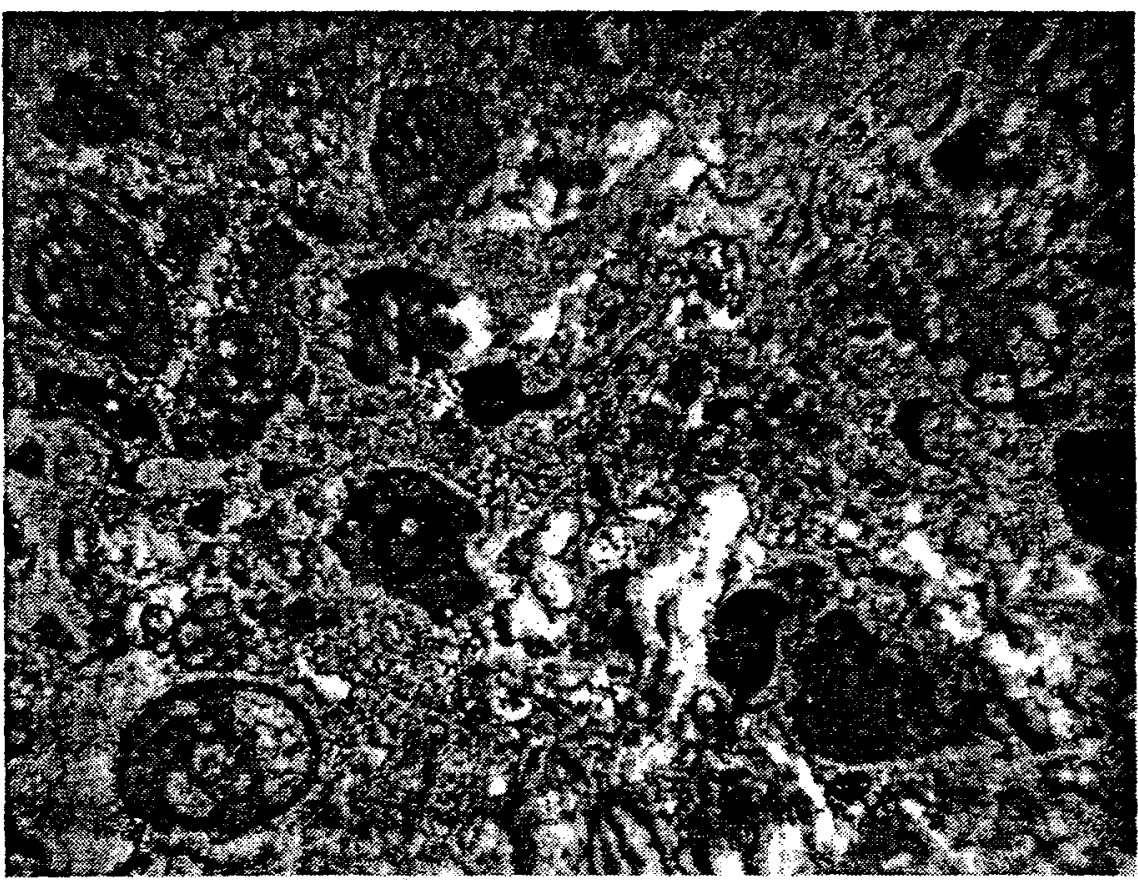

(B)

Figure 4.4. Photomicrographs of thin sections (plane light view) showing low-quality architectural lithotypes (24x). (A) Low-permeability mudstone from the Anasazi No. 1 well (sample depth $=5,622.6$ feet $[1,713.7 \mathrm{~m}]$ ). White objects are recrystallized calcite. (B) Lowpermeability grainstone from the Anasazi No. $5 \mathrm{~L}-3$ well (sample depth $=5,629.6$ feet $[1,715.8$ m]). White areas are pore-filling calcite cement; dark objects are bioclastic fragments. 


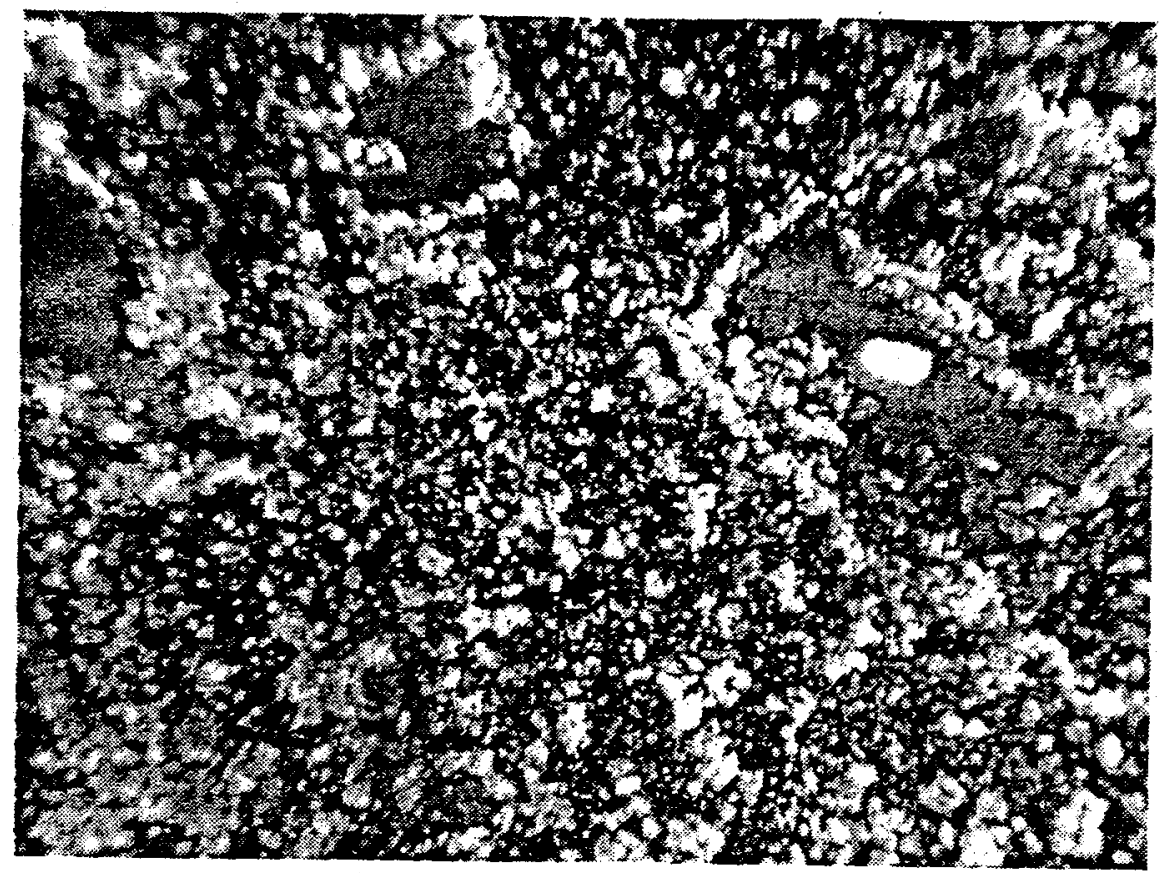

(A)

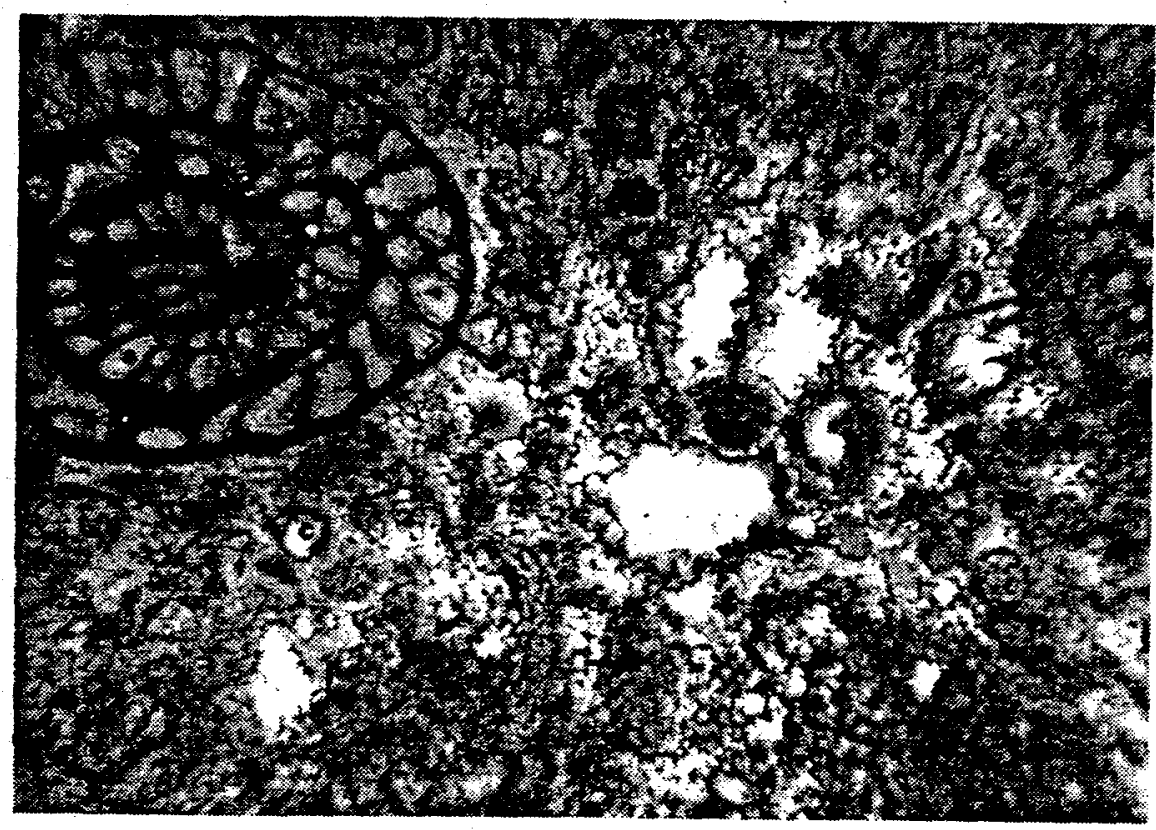

(B)

Figure 4.5. Photomicrographs of thin sections (plane light view) showing high-quality architectural lithotypes (24x). (A) Dolomitized mudstone, with enhanced porosity, from the Anasazi No. 6H-1 well (sample depth $=5,691.2$ feet $[1,734.6 \mathrm{~m}]$ ). Gray objects are enhanced pores, recrystallized dolomite is white, and interstitial bitumen is black. (B) Grainstone, with enhanced porosity, from the Anasazi No. 5L-3 well (sample depth $=5,616.2$ feet $[1,711.7 \mathrm{~m}]$ ). Pores are uniformly white to light gray with many lined with cement; dark objects are bioclastic fragments. 


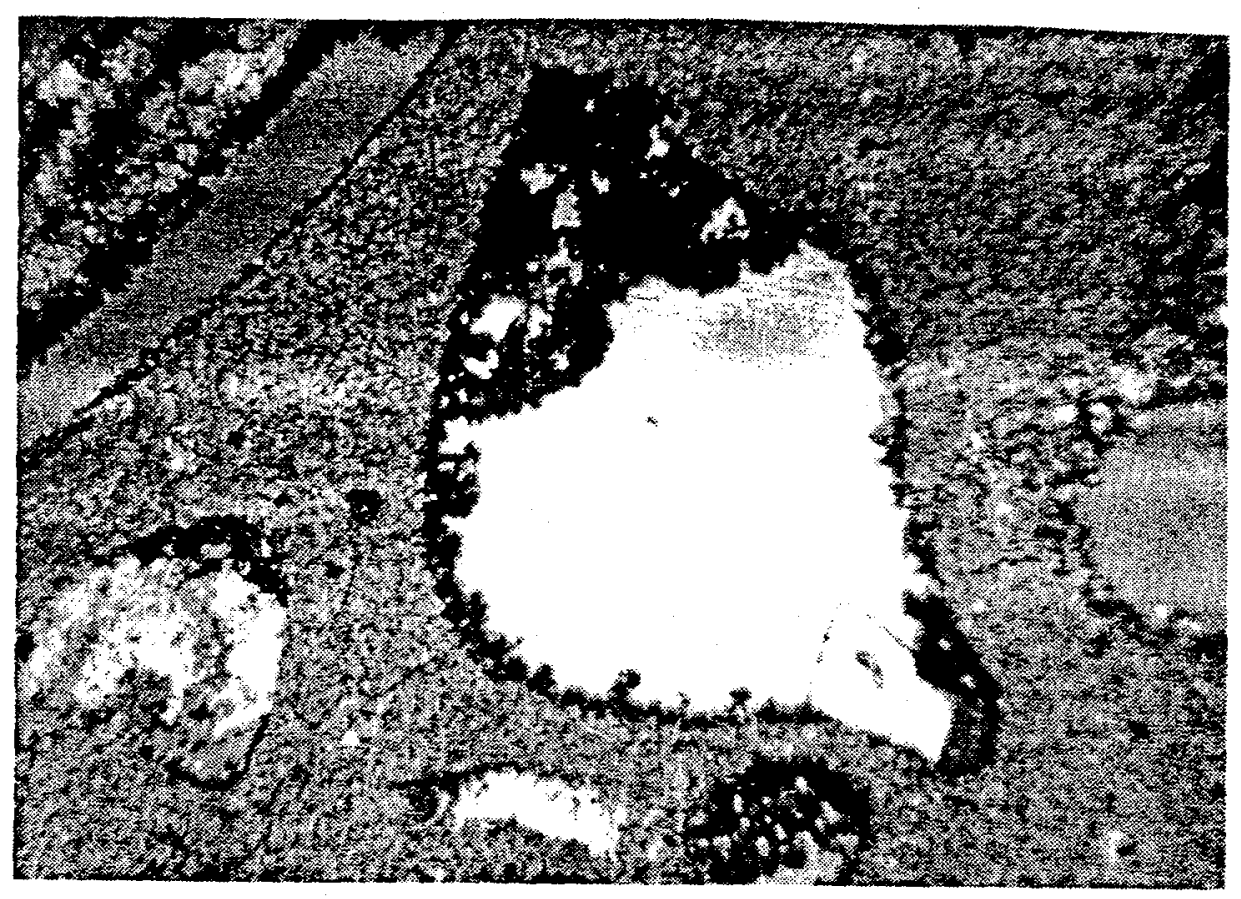

(A)

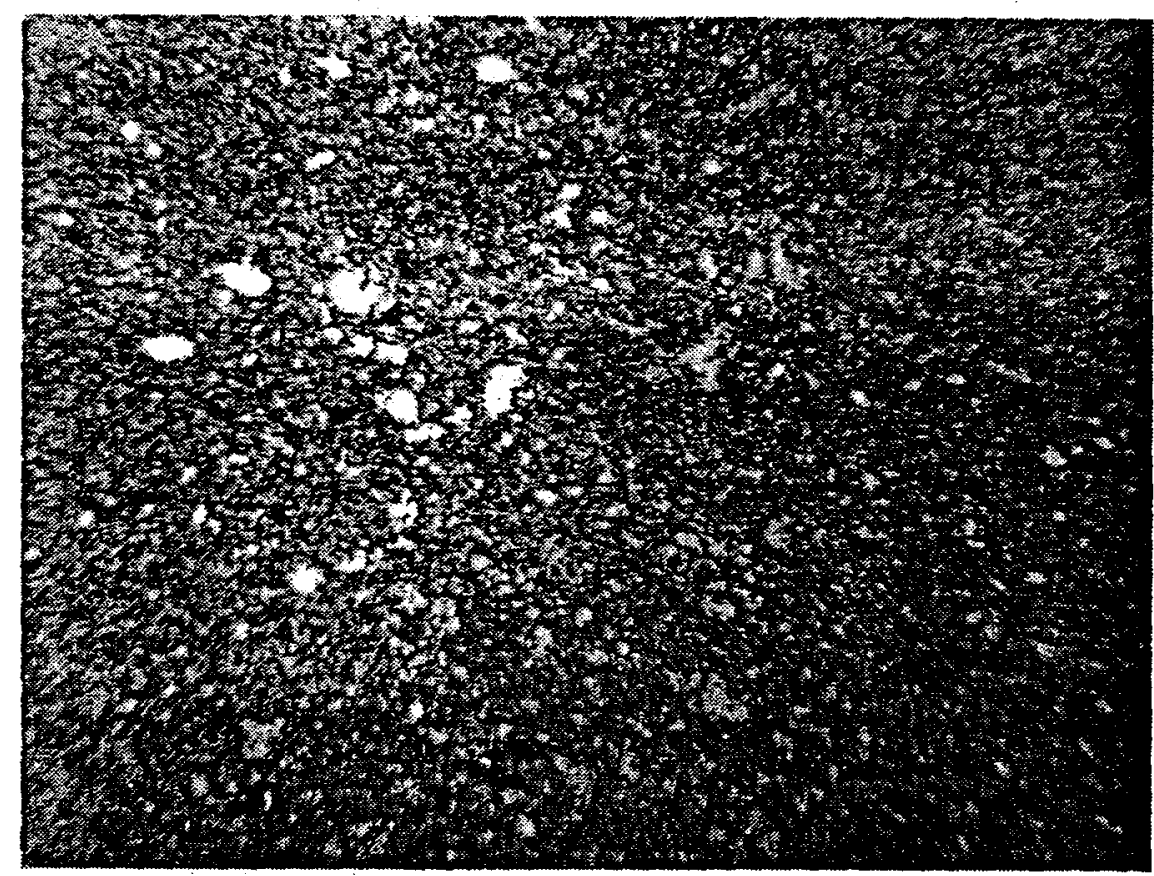

(B)

Figure 4.6. Photomicrographs of thin sections (plane light view) showing moderate- to highquality architectural lithotypes (24x). (A) Dolomitized packstone, with enhanced porosity, from the Anasazi No. 1 well (sample depth =5,621 feet [1,713 m]). Large, uniform white and gray objects are enhanced pores; pinpoint white and gray areas are microcrystalline dolomite, and black areas are residual bitumen. (B) Tùbular tempestite (relict burrow) from the Anasazi No. 1 well (sample depth $=5,601$ feet $[1,707 \mathrm{~m}]$ ). The burrow contains small and midsize pores (white objects) surrounded by undisturbed, tight dolomitized mudstone. 


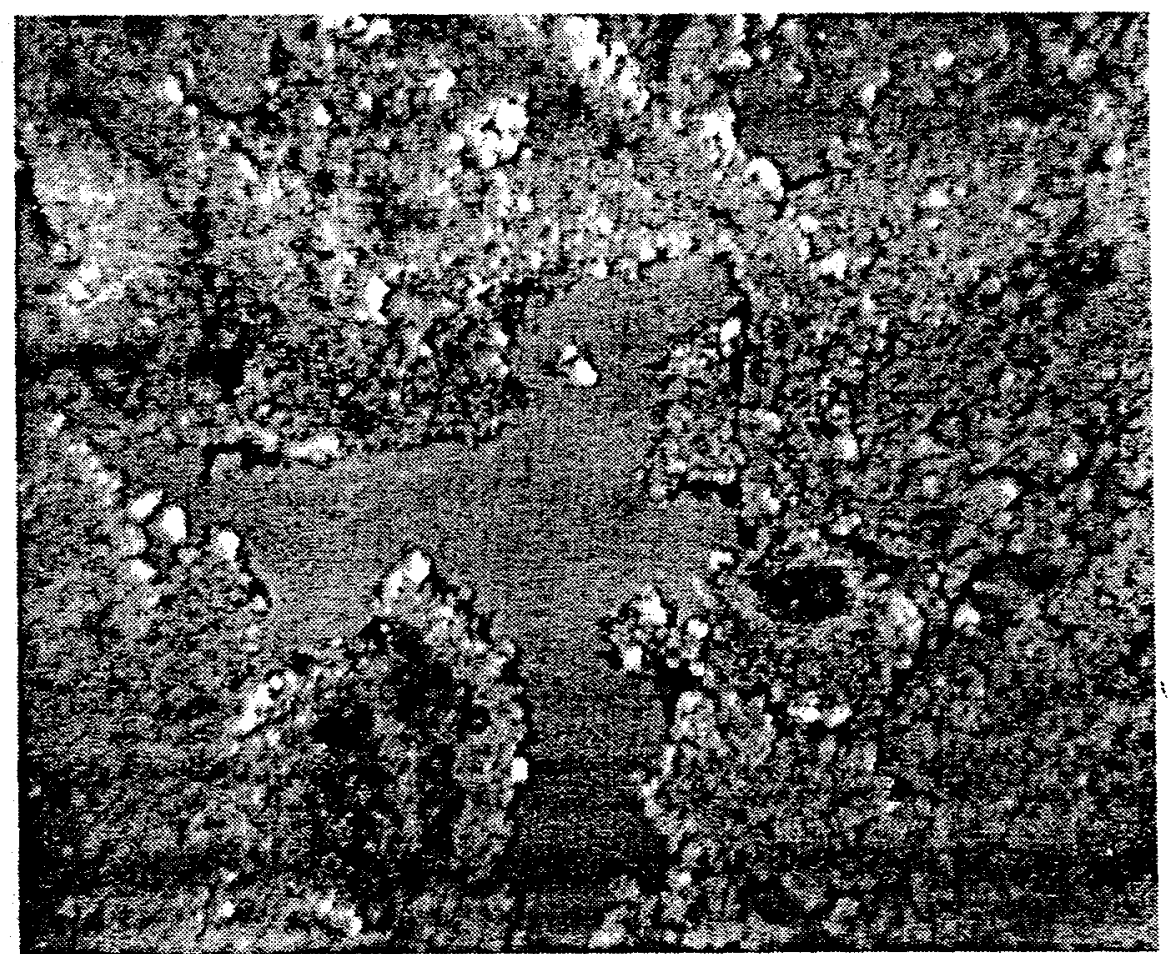

Figure 4.7. Photomicrograph of a thin section (plane light view) showing a phylloid algal bafflestone from the Anasazi No. 1 well (sample depth = 5,654.3 feet [1,723.3 m]) (24x). Large, irregularly-shaped, cement-lined pores (uniformly gray) are bounded by phylloid algal plates (dark elongate objects). 

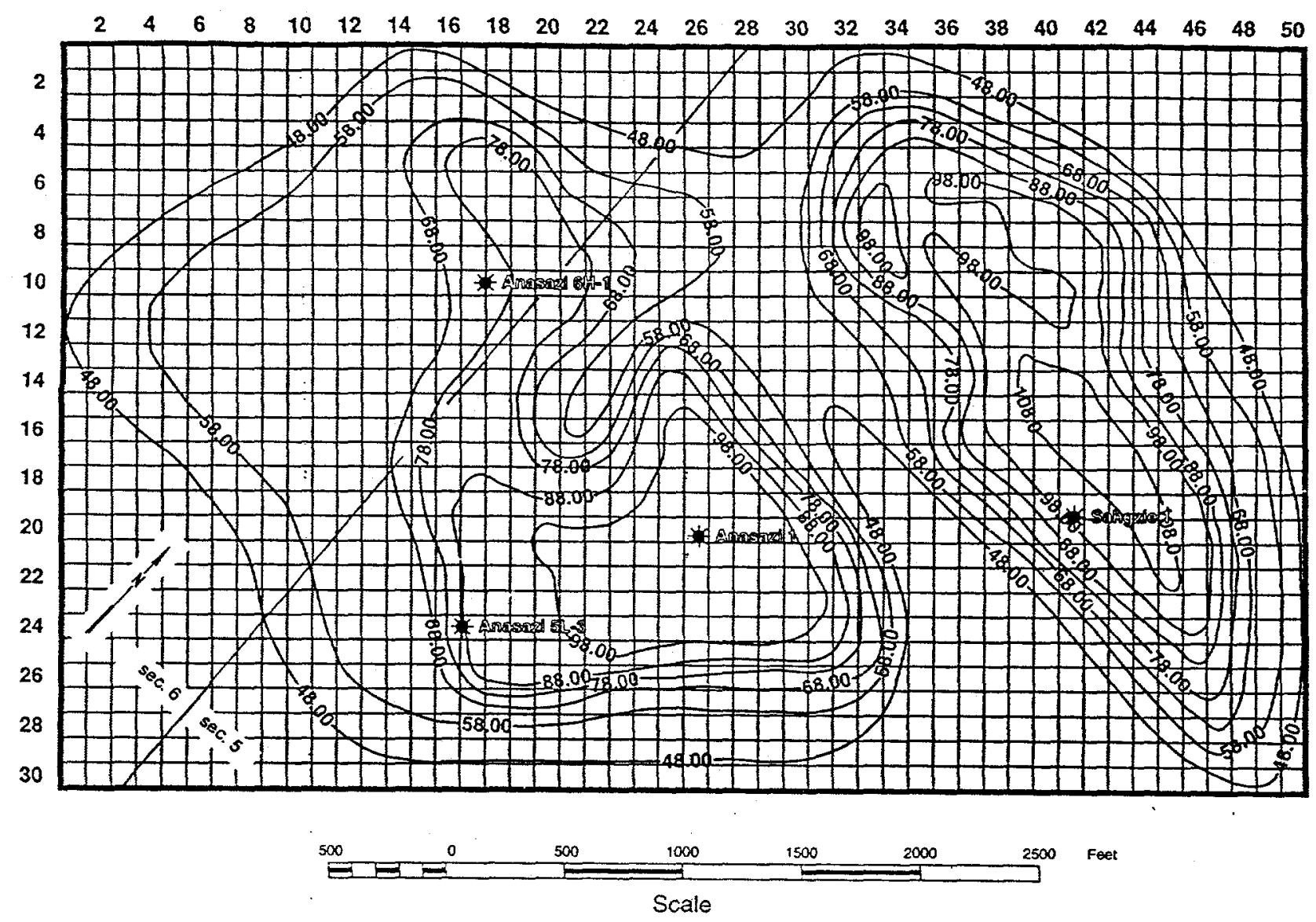

Figure 4.8. Anasazi reservoir gridded isolith map; contour interval $=10$ feet. Note that the geographic orientation of the map is rotated counterclockwise by $40^{\circ}$ relative to figure 4.1 .

to constrain the model using "soft" information from other sources. Fortunately, data from the six two-dimensional seismic lines over the Anasazi field (figure 4.1) are good quality and can be used to roughly characterize (constrain) lateral variations in average reservoir quality.

Based on two interpreted indices of reservoir quality from the common-depth-point stacked and migrated seismic cross sections, a single index (designated the "Reservoir Quality Index", or $\mathrm{RQI}$ ), scaled from 0 to 10 , was derived and mapped (figure 4.9). This map shows clearly that the best reservoir quality roughly coincides with areas of greatest mound buildup (figure 4.8). However, translation of RQI into equivalent quantitative expressions of standard reservoir properties is somewhat ambiguous. Acoustic properties of rocks are affected by such static reservoir properties as lithology, porosity, and thickness, but not (directly) by flow properties like permeability. Hence, since the original seismic interpretations were designed to complement the isochrons on which the reservoir thicknesses are based (figure 4.8), the RQI is likely to be primarily a function of porosity and lithology.

A plot of the RQI and average porosity derived from well logs in the four Anasazi wells (figure 4.10 ) shows that both lithology and porosity affect RQI. The anomalously low porosity 


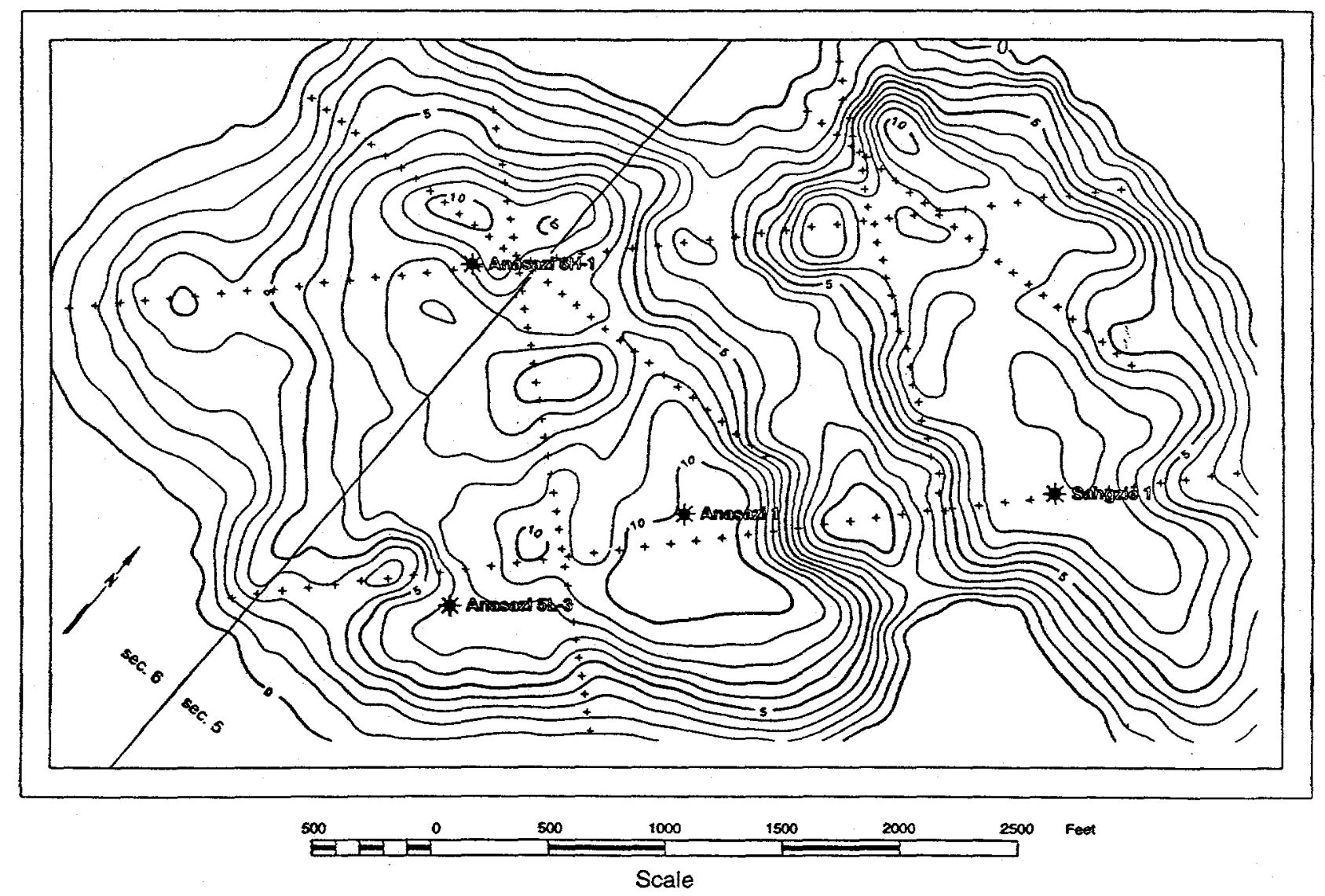

Figure 4.9. Reservoir quality index (RQI) map with seismic data points, Anasazi reservoir. Contour interval $=1$. 


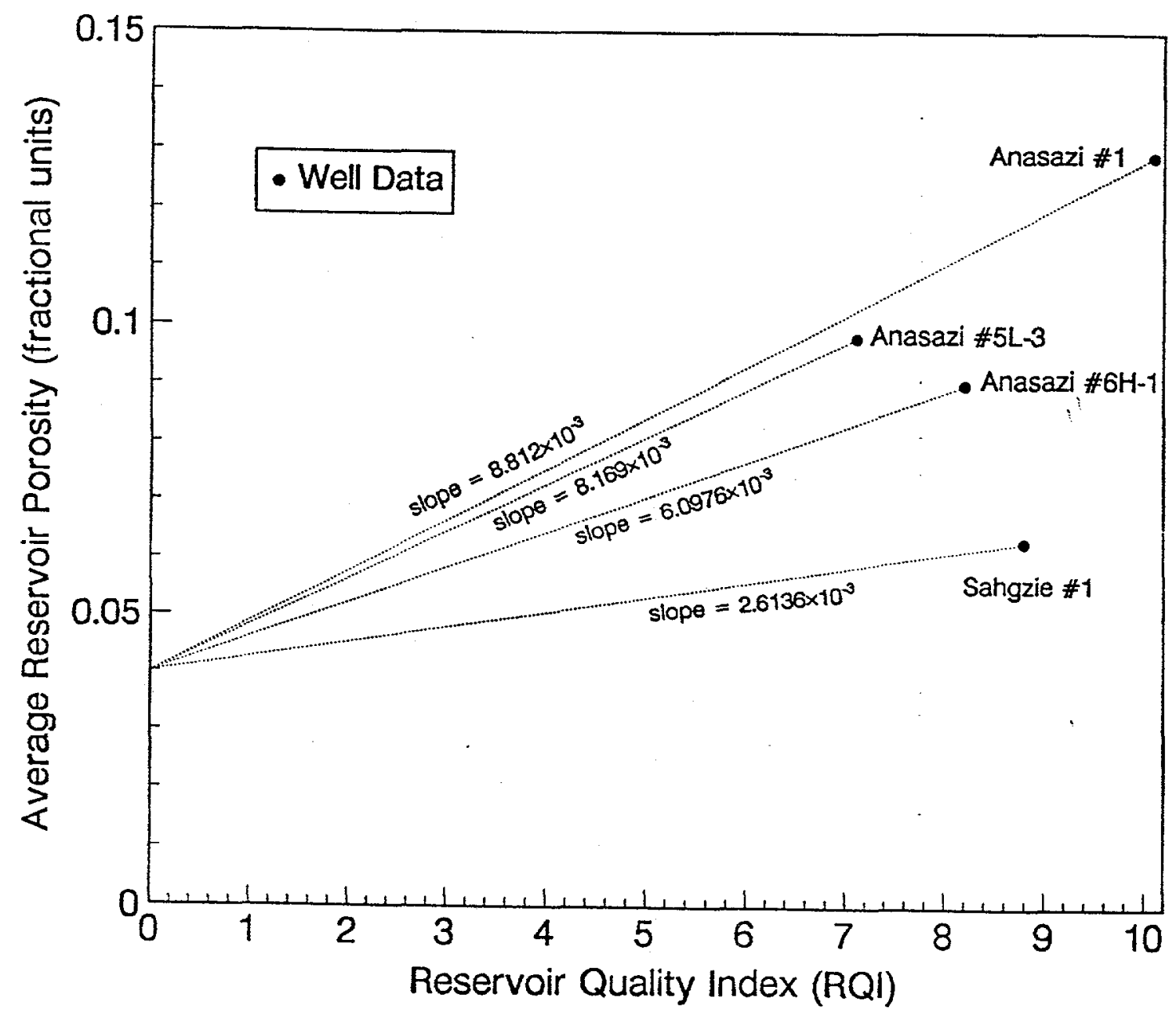

Figure 4.10. Estimation of average porosity from RQI, Anasazi reservoir. 
relative to the high RQI in the Sahgzie No. 1 well is chiefly attributable to massive anhydrite plugging in the supra-mound dolomites (figure 4.3D). Because the distribution of anhydrite in the reservoir is unknown, the RQI-to-average porosity transfer function is defined as a separate linear function at each well (figure 4.10), thus fitting the hard data exactly. The common zero-intercept at an average porosity of 4 percent corresponds to the average porosity over all non-pay intervals among the four wells. At grid points between the wells, the slope coefficient is defined as an inverse-distance weighted average of the slopes at the four wells (figure 4.10). The resulting map of average reservoir porosity (figure 4.11) will be used as a constraining variable for lateral variation in the reservoir modeling.

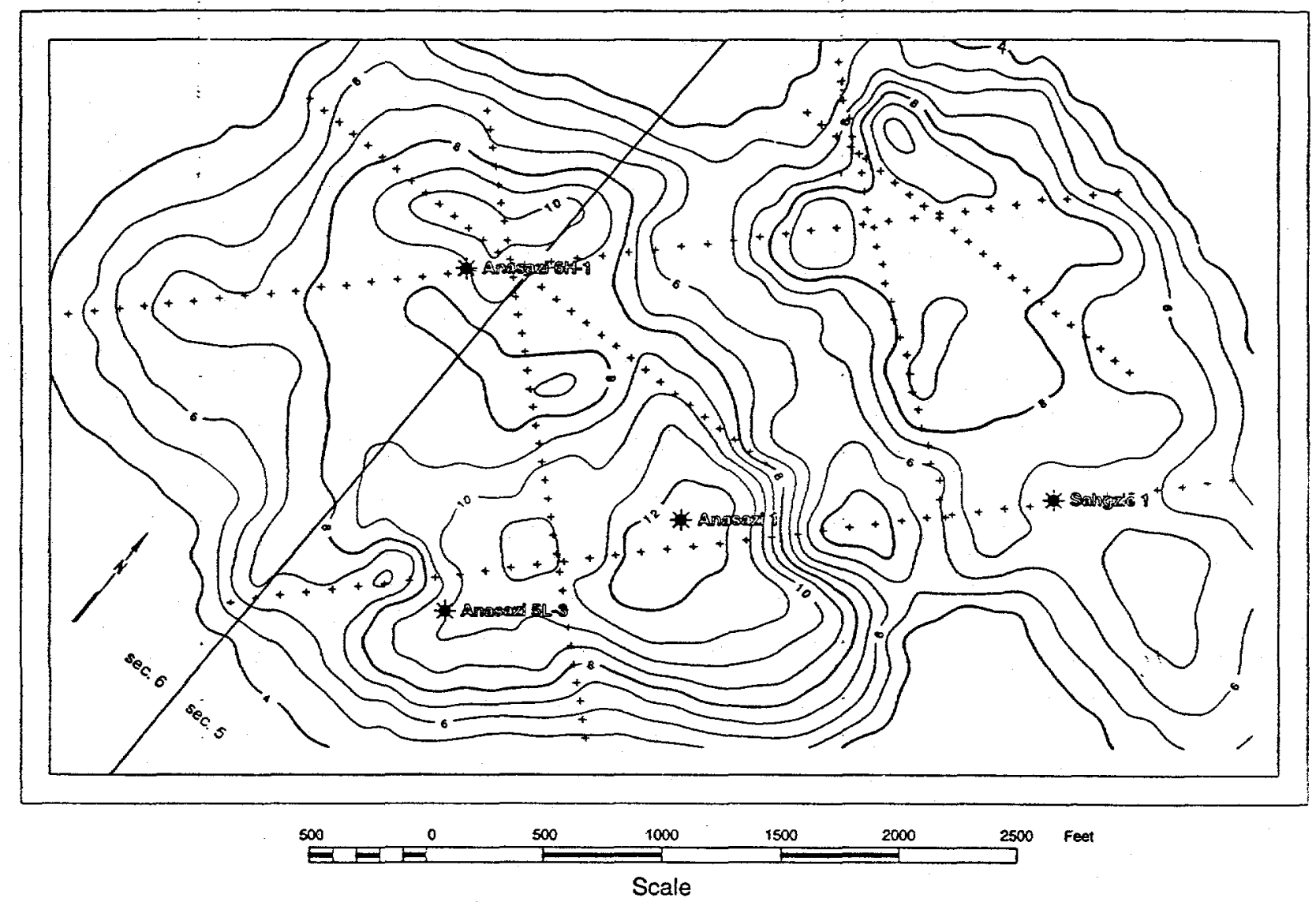

Figure 4.11. Map of average porosity derived from the RQI, Anasazi reservoir. Contour interval $=1$ percent.

\subsection{Reservoir Model Design}

Although significant vertical and lateral variations in reservoir properties characterize the Anasazi reservoir, these variations can be partially resolved by representing the different lithotypes as distinct architectural components, within each of which the pattern of spatial variation distinctive 
of that lithotype can be treated individually. The overall modeling strategy is to first emplace the various lithotypes as separate "bodies" or "architectural objects" (a procedure termed "Boolean Emplacement"), then to rearrange individual grid blocks (under appropriate geological constraints) to improve conformance to the seismic-based average porosity constraint (see section 4.4, Seismic Constraints), and finally to generate local patterns of vertical and lateral porosity variation within each lithotype using conventional geostatistical methods (Sequential Gaussian Simulation). Permeability will be generated from the modeled porosity using crossplot transfer functions developed from core data. At all stages of model development, the hard reservoir property data from the wells themselves is rigorously honored.

The data required to carry out the modeling procedures outlined above have been obtained from a number of different sources. Information on architectural lithotypes, their averages and ranges of reservoir properties, stratigraphic distribution/succession, porosity/permeability relationships and layering/interface properties is based on logs and cores from the Anasazi wells. Geometric properties of the various architectural elements (for example packstone/wackestone patches, tidal-channel grainstones, and mound-flank breccias) were obtained from the outcrop investigations. The average porosity constraint on lateral spatial variation is based on seismic interpretation. Inferred patterns of vertical variation within each lithotype are based on well logs and cores; patterns of lateral variation have been developed from the outcrop studies and published information on Aneth field and its analogues (Best and others, 1995). These modeling procedures are currently being developed; implementation and generation of the initial reservoir models is anticipated during the first quarter of 1996.

\subsection{References}

Best, D.A., Wright, F.M., III, Sagar, Rajiv, and Weber, L.J., 1995, Contribution of outcrop data to improve understanding of field performance: rock exposures at Eight Foot Rapids tied to the Aneth field, in Stout, E.L., and Harris, P.M., editors, Hydrocarbon reservoir characterization - geologic framework and flow unit modeling: Society of Economic Paleontologists and Mineralogists Short Course No. 34, p. 31-50.

Wilson, J.L., 1975, Carbonate facies in geologic history: Springer-Verlag, New York, 471 p. 


\title{
5. ENGINEERING RESERVOIR CHARACTERIZATION OF THE CARBONATE RESERVOIR IN THE DESERT CREEK ZONE
}

\author{
W.E. Culham \\ REGA Inc.
}

Two processes, with appropriate variations, are being evaluated for selection of the best (from a standpoint of oil recovery and economics) for implementing in a field pilot or demonstration project. Prior to evaluation of the two processes it will be necessary to model and history match the primary production phase of the Anasazi reservoir. Thus, the following general class of simulation studies will be performed:

1. primary depletion (history match),

2. waterflood, and

3. $\mathrm{CO}_{2}$ flood.

A compositional simulation approach is being used to model all three processes. A compositional approach properly accounts for oil vaporization (high API gravity oils) during primary depletion and will provide the correct oil compositions to subsequently assess $\mathrm{CO}_{2}$ flooding potential. Perhaps a black oil approach could be used for the waterflood study, but again, potential compositional changes and their impact on resaturation of the oil with gas during fill up would be most rigorously accounted for in a compositional approach. Thus, compositional simulation was selected for all process evaluations.

The main components of the engineering portion of the work are:

1. review of existing field data including re-evaluation of well test data,

2. reservoir fluid and rock characterizations via an extensive laboratory program,

3. reservoir development (history match, process design/evaluation for waterflood and $\mathrm{CO}_{2}$ ), and

4. economics.

To date work has been primarily completed on the first two items and some preliminary mechanistic two-dimensional reservoir simulation studies were completed using a simplified geologic model of the reservoir. These four work items are reviewed in the following sections.

\subsection{Review of Existing Field Data and Re-evaluation of Well Test Data}

\subsubsection{Field Data Review}

Basic field information reviewed for this study included historic production data for the Anasazi field, a review of special core tests (such as relative permeability data), and fluid characterization studies on associated Paradox basin reservoirs. 
Historic production data for individual wells in the field were reformatted into data files for use during simulation work to provide a basis for comparing actual historic well/field performance versus simulation generated data to facilitate the history matching work.

Review of relative permeability data (only one study involving cores from Runway and Anasazi was available) provided the basis for assessing the validity of existing data based on new comprehension wettability and relative permeability measurements (discussed later).

The review of the fluid properties studies provided the basis for identifying appropriate data sets to incorporate into equation of state tuning employing newly derived fluid property data. This review identified basic "black oil" pressure-volume-temperature (PVT) studies from seven different reservoirs (Anasazi, Mule, Blue Hogan, Brown Hogan, Heron North, Runway, and Jack fields [figure 1.1]) were available for analysis. A review of compositions, bubble point pressures, and solution gas-oil ratios identified only the Jack field as being appropriate to integrate with existing Anasazi data and the newly generated fluid characterization information. As discussed below the data sets will be integrated with the newly generated data to "tune" an equation of state for use in the compositional simulation work.

\subsubsection{Well Test Data Re-Evaluation}

Well test data, if properly attained, can provide key insight into the nature of reservoir heterogeneities and also provide "large scale" quantitative data on actual reservoir properties such as storage and transmissibilities. Because of the complex geologic nature of Paradox basin target reservoirs, a re-evaluation of past transient well tests was undertaken to assess if the nature of the test data contained enough information to provide a quantitative assessment of the two key oilproducing facies (supra-mound and mound-core intervals [referred to in this and the next section as dolomite and limestone respectively]) from case-study reservoirs. Although a number of well tests have been conducted in all of the target reservoirs, only the initial well tests, which were conducted under liquid saturated conditions (above bubble point) were determined to be useful in providing quantitative reservoir properties information. A list of well tests re-evaluated in detail include:

Reservoir Well
Brown Hogan No. 1A-2
Blue Hogan No. 1 J-1
Mule No. 31-M
Sahgzie No. 1
Sahgzie No. 1
Anasazi No. 1
Anasazi No. 1
Anasazi No. 1
Anasazi No. 1

\section{Test Date}

April 1991
February 1991
March 1992
July 1991
November 1989
January 1990
February 1990
January 1992
August 1993

To facilitate subsequent discussion, the following dual-property (porosity) well test parameters for the model type employed in the analysis are summarized below. 
Dual-porosity model:

Eq. 1

$$
\omega=\frac{\left(\phi c_{t} h\right)_{f}}{\left(\phi c_{t} h\right)_{f}+\left(\phi c_{t} h\right)_{m}}
$$

Eq. 2

$$
\lambda=\alpha r_{w}^{2} \frac{k_{m}}{k_{f}}
$$

Eq. 3

$$
\omega_{1}+\omega_{2}=1.0
$$

Eq. 4

$$
a=12 / h^{2} \text { slab }
$$

Eq. 5

$$
a=15 r_{s}^{2} \text { spherical }
$$

Eq. 6

$$
c_{t}=s_{w} c_{w}+s_{o} c_{o}+(1-\phi) c_{r}
$$

Fluid exchange between matrix and fracture:

- pseudo steady state

$$
k_{f}>100 k_{m}
$$

- one-dimensional transient

- three-dimensional transient

$$
k_{f}>10 k_{m}
$$

Two-layer model:

Eq. 7

$$
\omega=\frac{\left(\phi c_{t} h\right)_{1}}{\left(\phi c_{t} h\right)_{1}+\left(\phi c_{t} h\right)_{2}}
$$

Eq. 8

$$
\lambda=\frac{2 r_{w}^{2} k_{v}}{\left[(k h)_{1}+(k h)_{2}\right]\left[h_{1}+h_{2}\right]}
$$

Eq. 9

$$
\omega_{1}+\omega_{2}=1.0
$$


Variables used in the above equation are defined as:

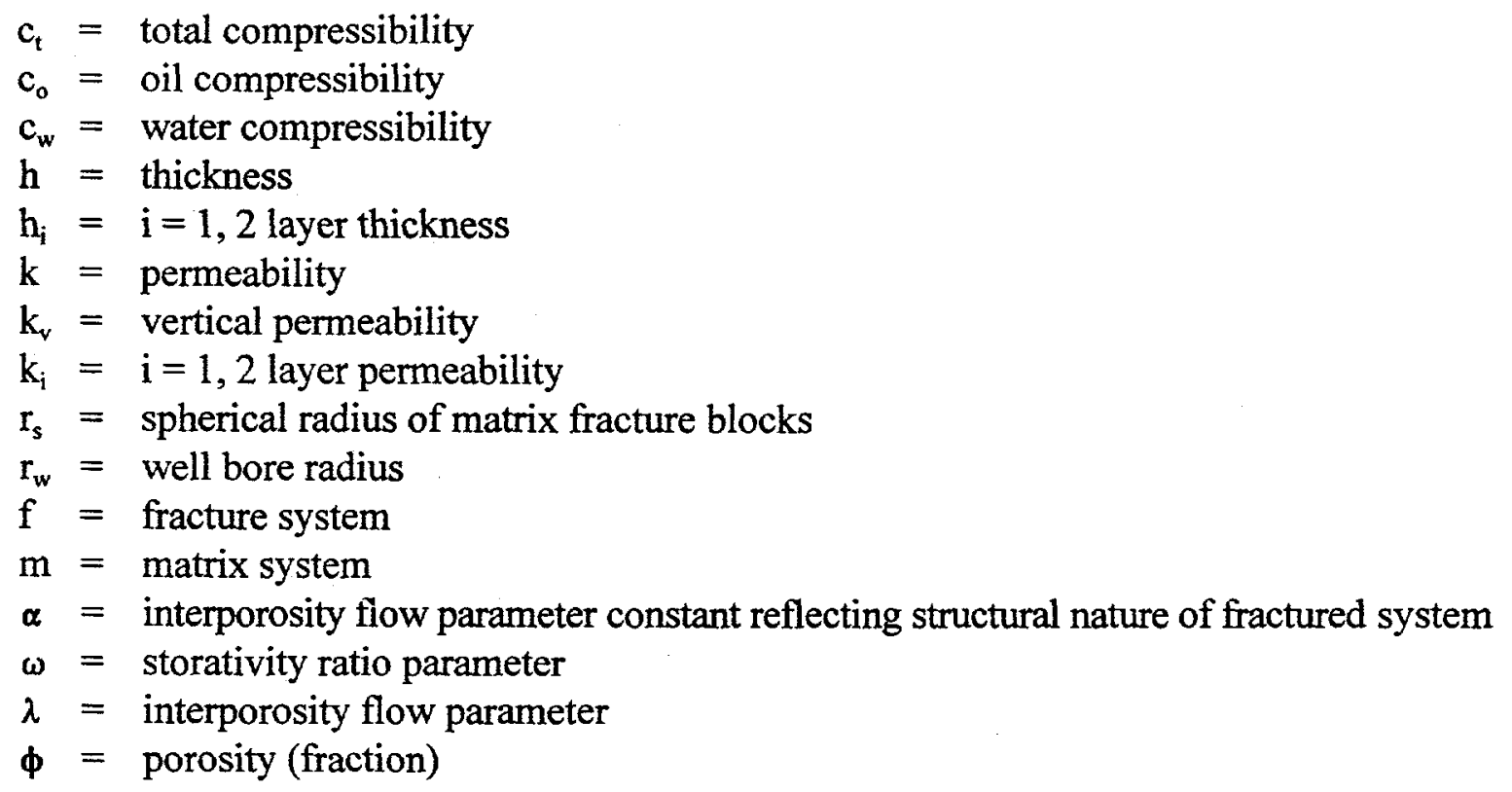

The parameter " $\omega$ " is simply the ratio of storage $\left(\phi c_{t} h\right)$ in one porosity unit to the total storage. The parameter " $\lambda$ " provides a measure of interporosity flow or fluid communication as governed by the absolute permeability thickness product (or effective permeability thickness) of the porous and permeable units in the model.

The geologic review of the producing formation provided basic guidelines in selecting the dual-property model. It is different from the classical definition for dual-porosity and layered systems. The conventional definition for a dual-porosity/dual-permeability system is based on one dominate rock type or facies that exhibits a characteristic primary (or matrix) porosity and permeability. This single rock type is also fractured. Thus, a secondary (fracture) porosity and permeability system is present which is substantially different than the primary system. In the case of the Desert Creek zone, two dominant lithofacies are present (supra-mound dolomite and moundcore algal bafflestone [limestone]). These two lithofacies serve to represent in a generic sense, a dual-property system. Each rock type representing a single layer in a two-layer model. One layer represents the limestone and the other the dolomite, each with their own characteristic reservoir properties. In reality the limestone layer is comprised of a number of interconnected limestone units "sampled" by the well test and the dolomite layer represents the composite behavior of possibly several interconnected dolomite units. The observed well test response is governed or reflects the interaction of the limestone facies with the dolomite facies. This type of response is consistent with data available in Bourdet (1985) which shows that behavior of multi-layer systems or heterogeneous systems characterized by high contrasts in rock properties among layers or units of the heterogeneous system can be modeled by using two elements (that is two layers). That is multi-layer systems or heterogeneous systems with two dominant sets of properties behave like conventional two-layer systems with cross flow between layers (or units). The above interpretation was applied to the Paradox basin reservoirs.

Unfortunately of all the tests analyzed, only one provided enough detailed information to allow a meaningful "dual-porosity" interpretation. Primarily, because the purpose of all early well tests was to provide information on production performance and perhaps skin factors, insufficient 
data was gathered for quantitative dual-porosity interpretations. The lack of appropriate data arose because the frequency at which the pressure data was measured was too coarse and because the duration of most tests was too short. The single test that could be quantitatively analyzed with a "dual-porosity" model was the Anasazi No. 1, January 1990 test.

Figures 5.1 to 5.3 present the match between measured data ( + symbol) and well test interpretation results (solid line) using a two-layer model with cross flow employing the parameters listed on each figure. A good match was obtained and indicates that the main limestone producing unit (mound-core interval) can be characterized as having a permeability of $194 \mathrm{md}$ and the dolomite (supra-mound interval) a much lower permeability of $1.21 \mathrm{md}$. The storativity ratio " $\omega$ " indicates that roughly 3.5 percent of the storage of the combined system is contained in the limestone unit. This two-layer approach, with a similar range of properties, was employed in mechanistic simulation studies (discussed later in section 6., Mechanistic Reservoir Simulation Studies) and supports this well test interpretation.

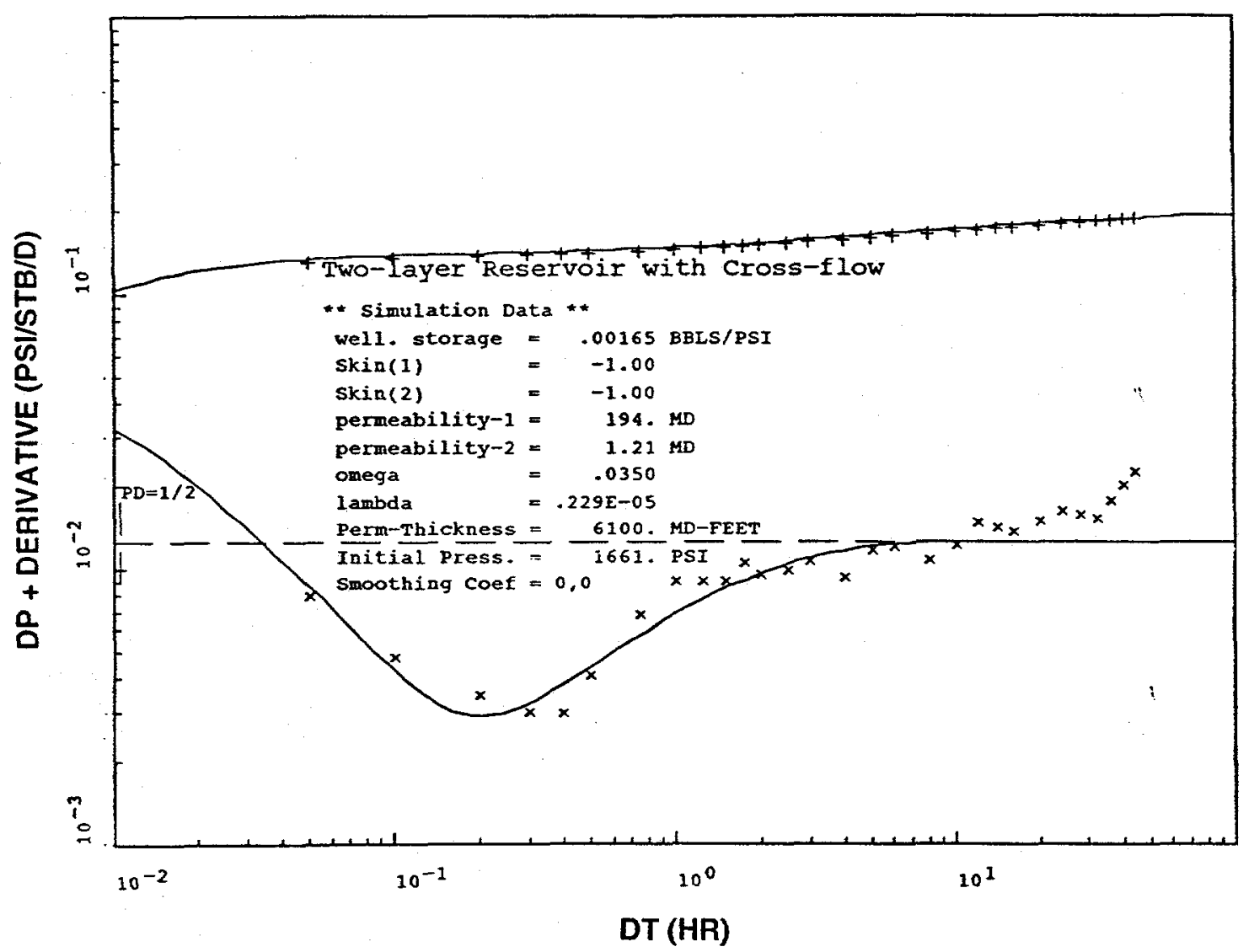

Figure 5.1. Anasazi No. 1 well test (1991) displaying pressure difference and pressure derivative match. 


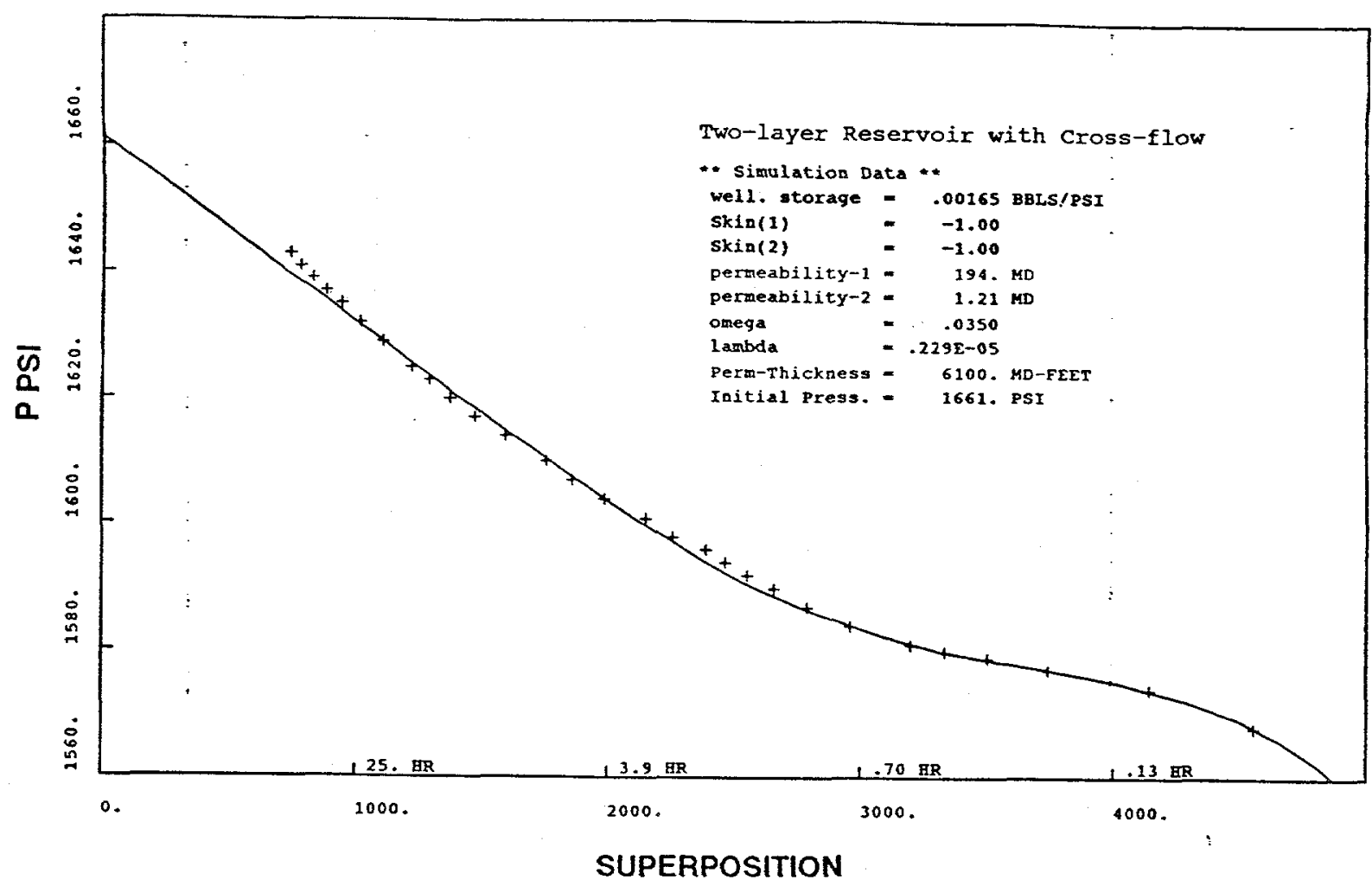

Figure 5.2. Anasazi No. 1 well test (1991) displaying superposition time vs. pressure match.
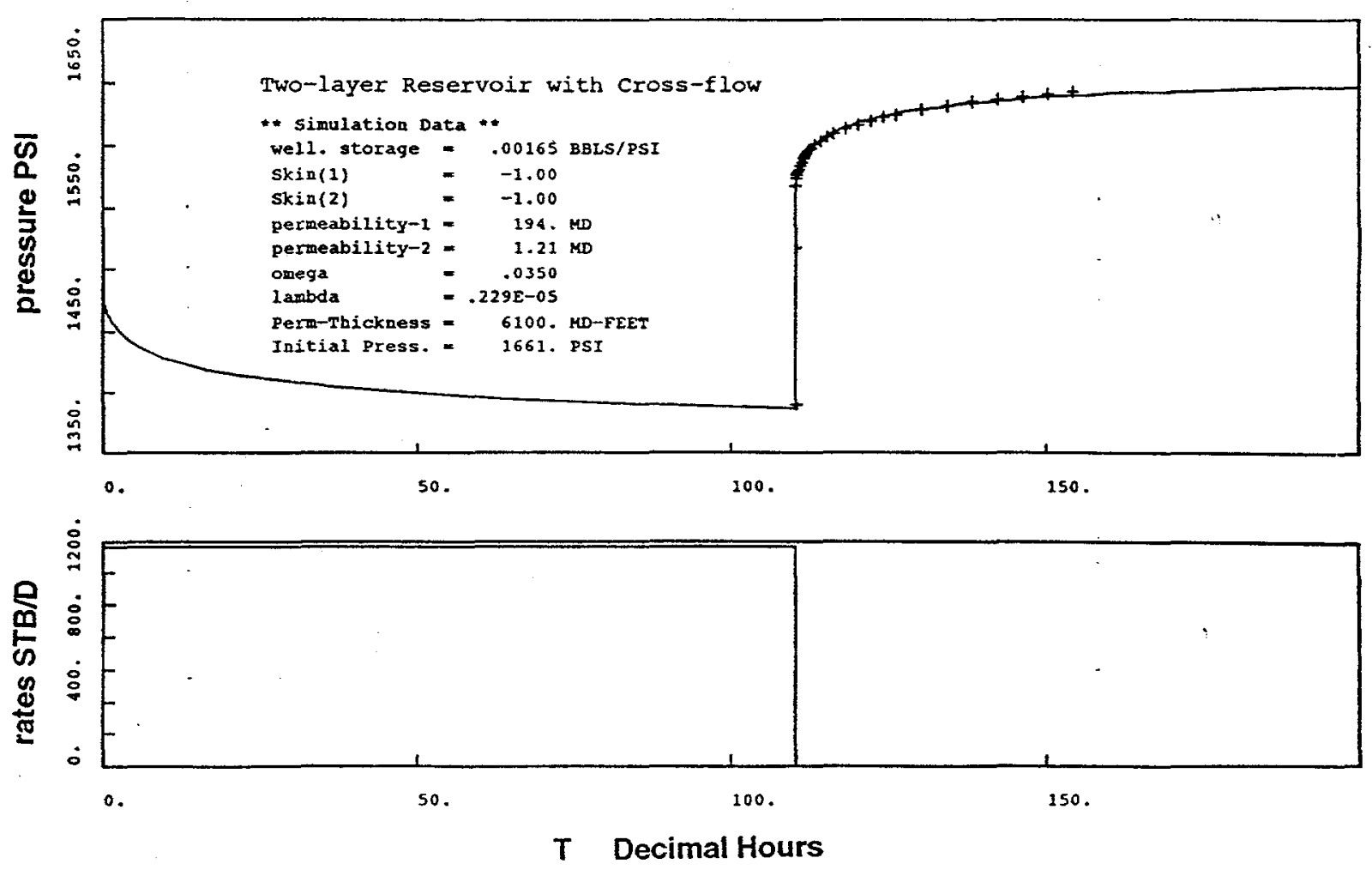

Figure 5.3. Anasazi No. 1 well test (1991) displaying pressure vs. time match. 


\subsection{Fluid Characterization}

Two recovery processes are being evaluated to assess recovery potential and identify recoverable reserves. The first is the waterflood, which can use fluid properties suitable for black oil reservoir studies. The second recovery process is $\mathrm{CO}_{2}$ gas injection. Since $\mathrm{CO}_{2}$ processes require compositional based data, more comprehensive fluid property data was needed. As discussed above, a compositional approach will be taken, even in the black oil cases. Existing black oil data may, however, be used to help in equation of state calibration activities. Review of existing PVT studies indicate an inadequate data set for compositional simulation and $\mathrm{CO}_{2}$ process evaluation. Thus, the following laboratory work was proposed and carried out. Assessment of the $\mathrm{CO}_{2}$ process will require calibration of an equation of state using the following data for tuning. The data includes:

1. extended (plus 30 carbon molecule $[\mathrm{C} 30+]$ ) compositional analysis on a recombined fluid sample,

2. a two-stage separator test, including a stock-tank condition, and

3. swelling tests employing four concentrations of $\mathrm{CO}_{2}$ with measurements of two-phase relative volumes at eight pressures for each mixture. Saturated liquid density and viscosity measurements for each mixture. Swelling tests used four discrete additions of injection gas $\mathrm{CO}_{2}$ which is added to the recombined reservoir oil.

A discussion and presentation of the results of the fluid composition work (extracted from D.B. Robinson Research Ltd. (1995) follows.

\subsubsection{Sample Preparation and Compositional Analysis}

The following Anasazi fluid samples were taken for study purposes:

- three separator oil cylinders (1 gal [3.8 L] each) labeled Anasazi 5L-3 field,

- three separator oil cylinders (one $500 \mathrm{~cm}^{3}$ and two $300 \mathrm{~cm}^{3}$ ) labeled Anasazi $5 \mathrm{~L}-3$ field, and

- three dead oil containers (1 gal [3.8 L] each) labeled as follows:

- $\quad$ Anasazi 5L-3

- $\quad$ Anasazi $6 \mathrm{H}-1$ limestone perforation $(5,723$ to 5,730 feet $[1,744-1,746$ m])

- $\quad$ Anasazi $6 \mathrm{H}-1$ dolomite perforation $(5,680$ to 5,694 feet $[1,731-1,735$ $\mathrm{m}])$. 
Note that one of the separator oil cylinders, namely W3A8302, was not properly filled during transferring; thereby, the corresponding fluid was not analyzed. Compositional analyses were conducted on separator oils, separator gases, and dead oils.

5.2.1.1 Separator Oils. The separator oils were initially equilibrated at 1,000 pounds per square inch gauge (psig [6,895 kpa]) and $73^{\circ} \mathrm{F}\left(23^{\circ} \mathrm{C}\right)$ (that is at single phase conditions). The separator conditions for these samples were reported to be $35 \mathrm{psig}(241 \mathrm{kpa})$ and $85^{\circ} \mathrm{F}\left(29^{\circ} \mathrm{C}\right)$. Next, samples of the separator oils were analyzed for their $\mathrm{C} 30+$ composition by the flash procedure. Accordingly, an accurately measured volume of each fluid was isobarically $(1,000 \mathrm{psig})$ displaced into a pycnometer where its density and mass were evaluated. The pycnometer was then connected to a gas-oil ratio (GOR) single stage flash apparatus where the fluid was flashed to ambient pressure and temperature conditions. Subsequently, the evolved gas phase was circulated through the residual liquid for a period of time to achieve equilibrium between phases. Following circulation, the volume of equilibrium vapor and the mass of liquid remaining in the pycnometer were measured. The vapor phase was resolved to $\mathrm{C} 5$ by gas chromatography (GC) while the vapor $\mathrm{C} 5+$ fraction and the residual liquids were analyzed to $\mathrm{C} 30+$. From the measured composition and total mass of each phase, the composition of the original live fluid was calculated by a mass balance. The $\mathrm{C} 30+$ compositions of the two separator oils analyzed are listed in tables B.1 and B.2, Appendix B. Both separator oil samples are fairly representative of one another for they have similar compositions, densities, and GORs.

5.2.1.2 Separator Gases. Separator gases from the $300 \mathrm{~cm}^{3}$ cylinders were analyzed for composition using GC analysis. The results so obtained are listed in tables B.3 and B.4, Appendix B. Both gases have essentially the same compositions within the accepted GC precision.

5.2.1.3 Dead Oil. The dead oil samples received were heated in their respective containers to $120^{\circ} \mathrm{F}$ $\left(49^{\circ} \mathrm{C}\right)$ and then agitated to homogenize them. Thereafter, a hot sample of each dead oil was dissolved in carbon disulfide and analyzed for composition using liquid $\mathrm{GC}$ analysis. The measured $\mathrm{C} 30+$ liquid compositions are presented in table B.5, Appendix B and plotted in figure 5.4. For ease of comparison, the corresponding results for the flashed separator oils are also included in this same table.

Before discussing these results, it is important to note that only the $5 \mathrm{~L}-3$ dead oil was flashed/collected directly from the separator. Both the dolomite and the limestone samples from the Anasazi No. $6 \mathrm{H}-1$ well were collected during swab test operations and stored on site and thus, because of the nature of the containers, were subject to light end losses.

As can be seen from table B.5, the dead oils have relatively higher $\mathrm{C} 30+$ fractions than the corresponding dead oils flashed from the separator oils (cylinder Nos. W4635 and W8301). More importantly, the Anasazi No. $6 \mathrm{H}-1$ limestone dead oil is observed to differ significantly in composition from the rest of the oil samples. The thermal histories, which the limestone and dolomite samples were subjected to, caused most of the light ends to evaporate. 


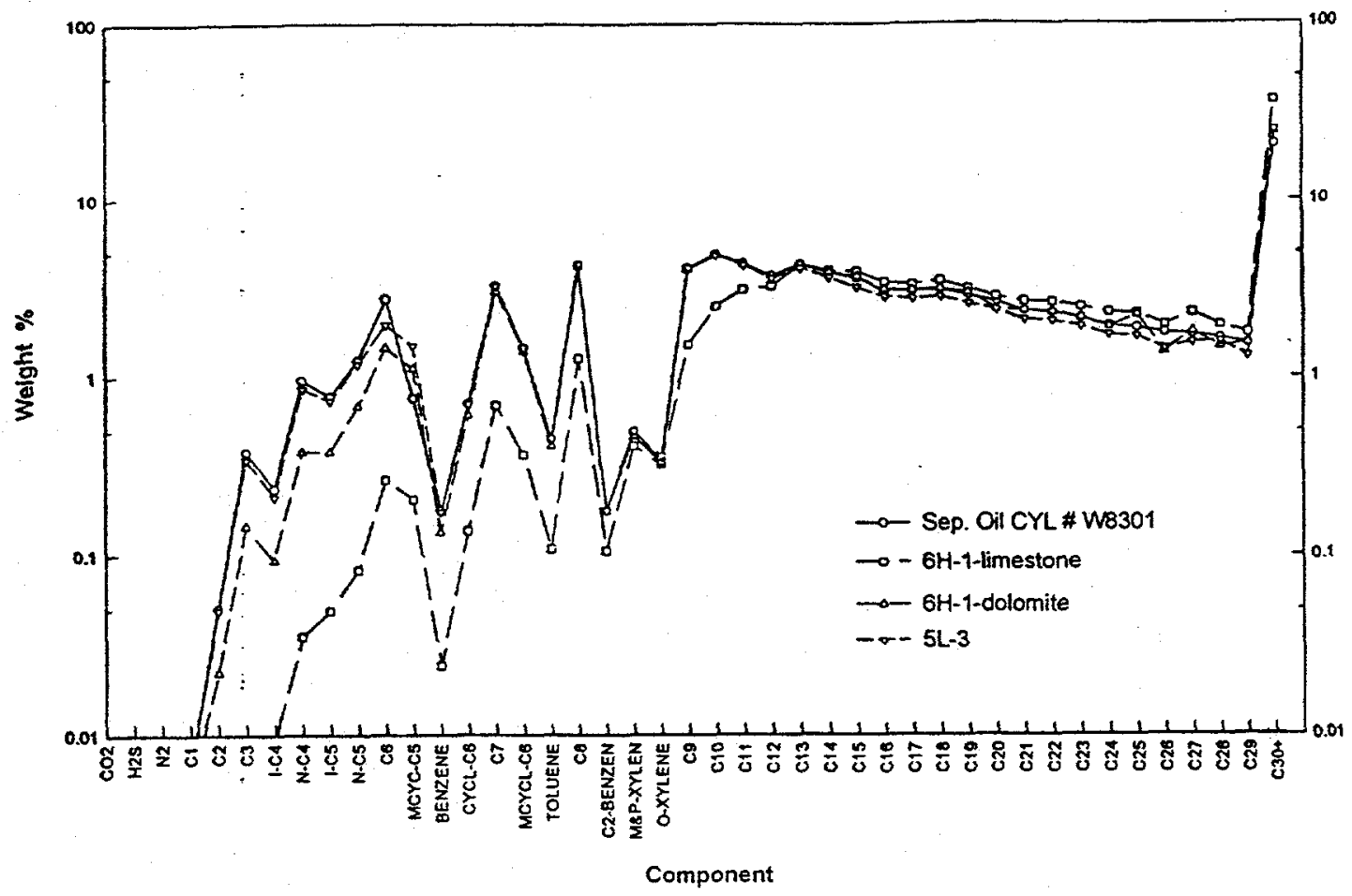

Figure 5.4. Comparison of the $(\mathrm{C} 30+)$ weight percent composition measured for the flashed separator oil and dead oil samples.

\subsubsection{Fluid Recombination and Swelling Tests}

5.2.2.1 Fluid Recombination. Separator oil and gas samples (synthetic) were recombined at a separator GOR of 1,208 standard cubic feet per stock tank barrel (scf/STB [ $242 \mathrm{~m}^{3}$ of gas $/ \mathrm{m}^{3}$ of oill). Details of the recombination are available in D.B. Robinson Research Ltd. (1995). The composition of the recombined sample is presented in table B.6, Appendix B.

5.2.2.2 Swelling Tests. Preliminary simulation studies of the Anasazi field indicated that if the field was re-pressured the existing free gas phase would be forced into solution in the oil and the remaining liquid would exhibit a bubble point of approximately 2,050 pounds per square in absolute (psia). This was selected as a reasonable starting point, from a fluid compositional standpoint, for $\mathrm{CO}_{2}$ swelling tests for future equation of state calibration work. Thus, the recombined fluid (table B.6) was used to prepare a fluid sample exhibiting a 2,050 psia $(14,135 \mathrm{kpa})$ bubble point at a reservoir temperature of $130^{\circ} \mathrm{F}\left(54^{\circ} \mathrm{C}\right)$. Details of the sample preparation are contained in D.B. Robinson Research Ltd. (1995). The composition of this mixture is presented in table B.7, Appendix B.

Using the reservoir fluid with a bubble point of 2,050 psia $(14,135 \mathrm{kpa})$, swelling tests employing 20,40,60, and 75 mole percent $\mathrm{CO}_{2}$ were conducted. Laboratory measurements consisted of determining a number of pressure-volume (PV) data points for each mixture and also measuring the density and viscosity of each saturated liquid mixture. A sufficient number of PV measurements in the single phase and two phase region were made for each mixture to allow 
determination of the bubble point or dew point of each mixture. Results of these tests are presented in tables C.1 through C.10, Appendix C. A summary of the swelling tests are presented in table 5.1.

Table 5.1. Swelling test data for the Anasazi No. 5L-3 oil at $130^{\circ} \mathrm{F}\left(54^{\circ} \mathrm{C}\right)$.

\begin{tabular}{|c|c|c|c|c|c|c|c|}
\hline \multirow{2}{*}{$\begin{array}{l}\text { (Mole\%) } \\
\text { Concentration } \\
\text { (Mold }\end{array}$} & \multicolumn{2}{|c|}{$\begin{array}{l}\text { Saturation pressure }) \\
\text { (psia) }\end{array}$} & \multirow{2}{*}{$\left(\mathrm{cm}^{3}\right)$} & \multirow{2}{*}{$\begin{array}{l}\text { Bhilk } \\
\text { Density } \\
\left(g / \mathrm{cm}^{3}\right)\end{array}$} & \multirow{2}{*}{$\begin{array}{l}\text { Wolaryolume } \\
\left(\mathrm{cm}^{3} / \mathrm{mol}^{\prime}\right)\end{array}$} & \multirow{2}{*}{$\begin{array}{l}\text { sweiling } \\
\text { ractort } \\
\left(\mathrm{cm}^{3} / \mathrm{cm}^{3}\right)\end{array}$} & \multirow{2}{*}{$\begin{array}{l}1 \\
(\mathrm{w}) \\
(\mathrm{CP})\end{array}$} \\
\hline & Measured & Predictedt & & & & & \\
\hline 00.0 & $2,050 t$ & 2,050 & 59.61 & 0.664 & 129.12 & 1.000 & 0.464 \\
\hline 20.0 & $2,294 t$ & 2,254 & 65.83 & 0.678 & 114.14 & 1.104 & 0.349 \\
\hline 40.0 & $2,585 t$ & 2,586 & 72.45 & 0.697 & 99.63 & 1.215 & 0.270 \\
\hline 60.0 & $3,176 t$ & 3,729 & 73.55 & 0.725 & 83.72 & 1.234 & 0.215 \\
\hline 75.0 & $5,800 \ddagger$ & & 78.20 & 0.805 & 67.63 & 1.312 & 0.210 \\
\hline
\end{tabular}

† Graphically

$\ddagger$ Visually

* Predicted by Robinson's EQUI-90

** Swelling Factor $=\mathrm{V}_{\text {sat }}$ (of $\mathrm{CO}_{2}+$ oil mixture) $\mathrm{N}_{\text {sat }}$ (virgin oil)

where $V_{\text {sax }}\left(\right.$ virgin oil) $=59.61 \mathrm{~cm}^{3}$

\subsubsection{Separator Tests}

A two-stage separator test was conducted. The first stage involved flashing recombined fluid at 3,014 psia and $70^{\circ} \mathrm{F}\left(20,782 \mathrm{kpa}\right.$ and $\left.21^{\circ} \mathrm{C}\right)$ to $35 \mathrm{psia}$ and $85^{\circ} \mathrm{F}\left(241 \mathrm{kpa}\right.$ and $\left.2^{\circ} \mathrm{C}\right)$. The second stage involved a flash to 0.0 psig and $60^{\circ} \mathrm{F}\left(16^{\circ} \mathrm{C}\right)$. Separator data are presented in tables 5.2 and 5.3; the gas compositional data are presented in table B.8, Appendix B.

\section{Table 5.2. Separator test volumetric data.}

Initial volume $=31.00 \mathrm{~cm}^{3}$ at 3,014 psia $(20,782 \mathrm{kpa})$ and $70{ }^{\circ} \mathrm{F}\left(21^{\circ} \mathrm{C}\right)$

1st Stage Flash $35 \mathrm{psig}(241 \mathrm{kpa})$ and $85^{\circ} \mathrm{F}\left(29^{\circ} \mathrm{C}\right)$

\begin{tabular}{|c|c|c|c|c|}
\hline & Volume $\left(\mathrm{cm}^{3}\right)$ & Density $\left(\mathrm{g} / \mathrm{cm}^{3}\right)$ & $\mathrm{MW}(\mathrm{g} / \mathrm{gmol})^{\mathrm{r}}$ \\
\hline Vapor & $1,248.16$ & 0.0037 & 26.19 \\
\hline Liquid & 19.72 & 0.7922 & \\
\hline
\end{tabular}

Initial volume $=24.97 \mathrm{~cm}^{3}$ at $35 \mathrm{psia}(241 \mathrm{kpa})$ and $85^{\circ} \mathrm{F}\left(29^{\circ} \mathrm{C}\right)$

2nd Stage Flash 0 psig (O kpa) and $60^{\circ} \mathrm{F}\left(16^{\circ} \mathrm{C}\right)$

\begin{tabular}{|c|c|c|c|c|c|}
\hline & Volume $\left.(\mathrm{cm})^{3}\right)$ & Density $\left(\mathrm{g} / \mathrm{cm}^{3}\right)$ & Gravity (APll) & MW (g/gmol) \\
\hline Vapor & 98.16 & 0.0014 & 39.14 \\
\hline Liquid & 24.76 & 0.8103 & 43.13 & \\
\hline
\end{tabular}

*MW = molecular weight 
Table 5.3. Separator test-produced GOR.

\begin{tabular}{|c|r|r|}
\hline $\begin{array}{c}\text { Stage } \\
\text { 1st Stage Flash }\end{array}$ & \multicolumn{2}{|c|}{ GOR } \\
(scfistB) & cumulative \\
\hline 2nd Stage Flash & $1,197.4$ & $1,197.4$ \\
\hline Total & 20.4 & $1,217.8$ \\
\hline
\end{tabular}

\subsubsection{Summary}

Detailed compositional analysis, separator tests and swelling tests involving four concentrations of $\mathrm{CO}_{2}$ were completed. Swelling factors exceeded 30 percent and oil viscosity was reduced by more than a factor of 2.0. This new fluid property data, in combination with existing basic black oil PVT data of the original reservoir fluid, provides the basis for calibrating or tuning an equation of state. The equation of state parameters will be used in the compositional reservoir simulation study to evaluate implementation of $\mathrm{a} \mathrm{CO}_{2}$ flood in typical Paradox basin reservoirs in the Desert Creek zone.

\subsection{Rock Characterization}

One of the key data sets required for reservoir recovery process evaluation via simulation is relative permeability data. Although, an extensive core inventory exists for the Paradox basin reservoirs in the Desert Creek zone, all cores are in a de-preserved state. With the drilling of the Anasazi No. 6H-1 well in 1995, an opportunity existed to obtain a fresh core and preserve the core. Preserved cores could then be used to conduct wettability and relative permeability measurements employing various core preparation procedures. Analysis of the resulting data from these measurements would thus provide guidelines for core preparation in future relative permeability work and provide a valid data set for future reservoir simulation studies. To this end representative samples from the preserved Anasazi No. 6H-1 core were taken (see section 3.3.2, Anasazi No. 6H-1 Well, Anasazi Field), based on CAT scans of the core, and used for a suite of capillary pressure, wettability, and relative permeability measurements.

Since a representative Desert Creek limestone interval was not present in the Anasazi No. $6 \mathrm{H}-1$ well, the tests were performed on samples from the dolomite interval. Then once the proper core preparation procedures were identified, de-preserved core material from another Anasazi well could be used for future limestone relative permeability measurements (Anasazi No. 1 well was selected and these tests are ongoing). In addition to the above discussed tests, samples from the Anasazi No. 6H-1 (dolomite) and Anasazi No. 1 (limestone) wells were used for rock compressibility measurements. Because an important part of the production life of the Paradox basin reservoirs in the Desert Creek zone involved liquid expansion and no compressibility data existed, it was important to obtain representative data to use in reservoir performance modeling. 
All these tests (except limestone relative permeability) have been completed and results are summarized in the following sections, using extracted material from Westport Technology Center International (1995) and TerraTek, Inc. (1995) reports.

\subsubsection{Relative Permeability Measurements}

5.3.1.1 Fluid Measurements. The brine used in these experiments was a synthetic formation brine. The water analysis was for a sample collected on July 28, 1995 from the Sahgzie No. 1 well separator. The sample was filtered through a 0.45 micron filter (see table 5.4) after mixing. The original brine was a saturated solution at ambient temperatures and was diluted to $3 / 4$ strength to prevent salt precipitation during the temperature cycling the samples were subjected to in the course of the testing.

The crude oil was obtained from the surface separator for Anasazi No. 5L-3 well in August 1995 and used after filtering through a 0.45 micron filter at $73^{\circ} \mathrm{F}\left(23^{\circ} \mathrm{C}\right)$. Fluid properties were measured from $73^{\circ} \mathrm{F}$ to $135^{\circ} \mathrm{F}\left(23-57^{\circ} \mathrm{C}\right)$ since fluid saturations had to be measured at ambient conditions and the experiments conducted at $130^{\circ} \mathrm{F}\left(54^{\circ} \mathrm{C}\right)$. Data is provided for the oil properties in table 5.5. The surface and interfacial tension measurements were made using a ring pull tensiometer and thus are nonequilibrium measurements.

Table 5.4. Brine composition.

\begin{tabular}{|l|r|}
\hline \multicolumn{1}{|c|}{$\mathrm{Brine}+\mathrm{Wt} \%$} \\
\hline Sodium Chloride $(\mathrm{NaCl})$ & 9.10 \\
\hline Calcium Chloride $\left(\mathrm{CaCl}_{2} \cdot 2 \mathrm{H}_{2} \mathrm{O}\right)$ & 6.00 \\
\hline Magnesium Chloride $\left(\mathrm{MgCl}_{2} \cdot 6 \mathrm{H}_{2} \mathrm{O}\right)$ & 2.00 \\
\hline Potassium Chloride $(\mathrm{KCl})$ & 0.23 \\
\hline
\end{tabular}

Table 5.5. Fluid properties.

\begin{tabular}{|c|c|c|c|c|c|}
\hline Fluid & Temp (F) & $\begin{array}{c}\text { Density } \\
(\mathrm{g} / \mathrm{cm})\end{array}$ & $\begin{array}{c}\text { Viscosity } \\
(\mathrm{cP})\end{array}$ & $\begin{array}{c}\text { Interfacial Tension } \\
\text { (dynes/cm) }\end{array}$ & $\begin{array}{c}\text { Surface Tension } \\
\text { (dynes/cm) }\end{array}$ \\
\hline Brine & 75.000 & 1.1930 & 1.975 & 17.200 & 15.600 \\
\hline Brine & 130.000 & 1.1791 & 1.005 & 4.730 & 26.800 \\
\hline Crude Oil & 75.000 & 0.8229 & 2.580 & & 25.500 \\
\hline Crude Oil & 130.000 & 0.8014 & & & \\
\hline
\end{tabular}

5.3.1.2 Experimental Procedures. Data collected was analyzed using techniques by Hirasaki and others (1990). The capillary pressure data was analyzed using a constrained Hassler-Brunner modeling technique. The relative permeability experiment was an unsteady state displacement in 
which only the displaced phase permeability can be analyzed. The data was corrected for capillary hold up, invading phase mobility, and speed ramp up effects then fitted to a bimodal Corey model to account for mobility shock production.

5.3.1.3 Resaturation and $K_{e w}$ Measurements. Because of the saturated condition of the reservoir brine, all samples were flushed with the lower salinity brine in an attempt to remove any precipitated salts from the materials. Samples $1 \mathrm{a}, 1 \mathrm{~b}, 2$, and $4 \mathrm{a}$ had "as received" flowing permeabilities measured using this brine. Core 2 was then cleaned using a sequential solvent flow cleaning procedure and cut into samples $2 \mathrm{a}$ and $2 \mathrm{~b}$. Core $1 \mathrm{a}$ was then flow cleaned using the same equivalent solvent cleaning technique. Cores $1 \mathrm{a}$ and $2 \mathrm{~b}$ were then brine saturated under $500 \mathrm{psi}(3,448 \mathrm{kpa})$ back pressure and effective water permeability $\left(\mathrm{K}_{\mathrm{ew}}\right)$ values measured at 100 percent brine saturation.

5.3.1.4 Initial Oil/Brine Drainage Experiment and Aging. An initial oil/brine drainage capillary pressure experiment was conducted on cores $1 b$ and $2 b$ to establish a high initial oil saturation for the aging process. Aging was accomplished for 14 days at $130^{\circ} \mathrm{F}\left(54^{\circ} \mathrm{C}\right)$. Near the end of the aging process an oil/brine drainage capillary pressure experiment was conducted on core 1a to establish a high initial oil saturation without the aging of the other cores.

5.3.1.5 Brine/Oil Imbibition Capillary Pressure Test. Initial flowing oil permeabilities were measured and then an imbibition capillary pressure experiment was conducted for use in wettability determination. A comparison of the data is given in figure 5.5. The curve shapes indicate a wetting oil condition since the oil saturation continues to decrease with increased capillary pressure until a value below 5 percent remaining oil is achieved near $100 \mathrm{psi}(690 \mathrm{kpa})$. Comparisons of the core entry values using the Leverett " $\mathrm{J}$ " function seen in figure $5.5 \mathrm{~B}$ indicate a slightly stronger oil wetting condition in the preserved and restored cores over the cleaned but unrestored core.

5.3.1.6 $\mathrm{K}_{\mathrm{ew}}$ Measurements and Oil/Brine Secondary Drainage Test. The samples were mounted in flow cells with an overburden pressure of $1,000 \mathrm{psi}(6,895 \mathrm{kpa})$ and heated to $130^{\circ} \mathrm{F}\left(54^{\circ} \mathrm{C}\right)$. Brine was then introduced and a fluid pressure of $500 \mathrm{psi}(3,448 \mathrm{kpa})$ maintained while the $\mathrm{K}_{\mathrm{ew}}$ at residual oil saturation $\left(\mathrm{S}_{\mathrm{or}}\right)$ measurements were taken. The samples were cooled while maintaining the $500 \mathrm{psi}(3,448 \mathrm{kpa})$ fluid pressure. The samples were then placed in the centrifuge drainage cells. The cells were heated to $130^{\circ} \mathrm{F}\left(54^{\circ} \mathrm{C}\right)$ and a multi-speed experiment was conducted to determine the secondary drainage capillary pressure curves presented in figure 5.6. The Leverett " $\mathrm{J}$ " function curves indicate stronger water wetting in core $1 \mathrm{a}$ with the preserved core $1 \mathrm{~b}$ having the least water wetting condition.

5.3.1.7 Brine/Oil Imbibition Relative Permeability Test. Initial flowing oil permeabilities were measured and then an imbibition capillary pressure experiment was conducted for use in wettability determination. A comparison of the data is given in figure 5.7. The initial permeabilities were fixed to the measured initial flowing permeabilities and the data then history matched to produce the curves. The final oil saturation to which the curves are plotted is the final average saturation in the cores. This explains why the saturations are not as low as the capillary pressure final saturations which are the saturations calculated at the inflow end of the core. 


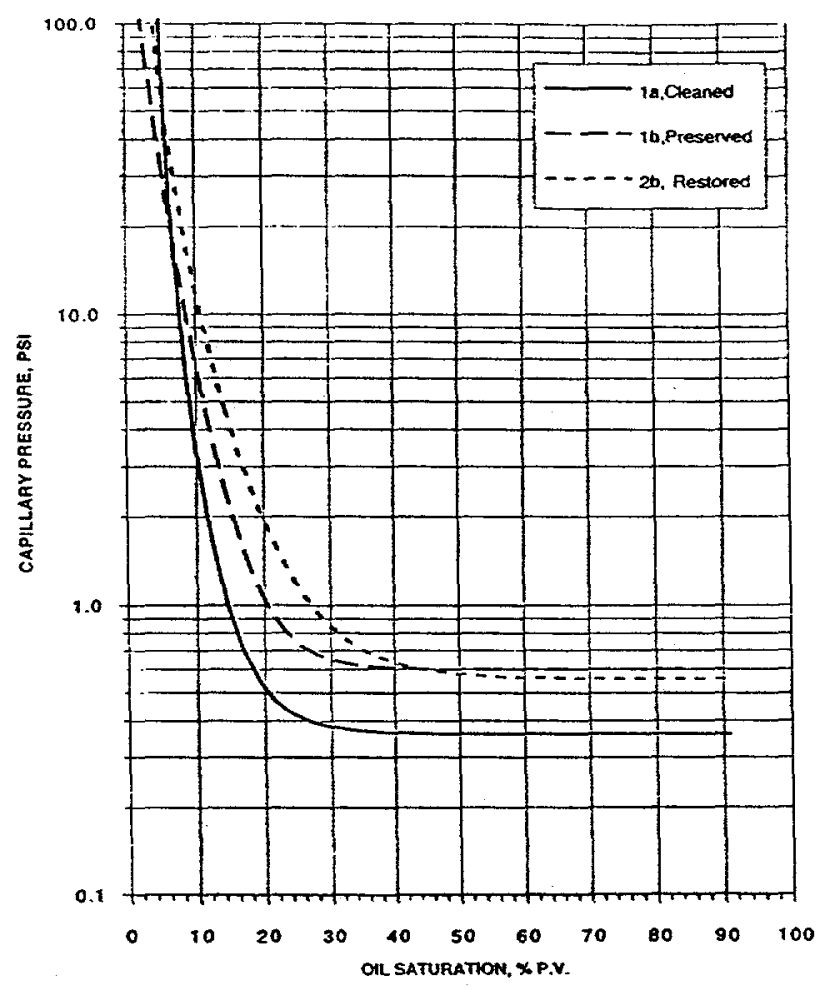

(A)

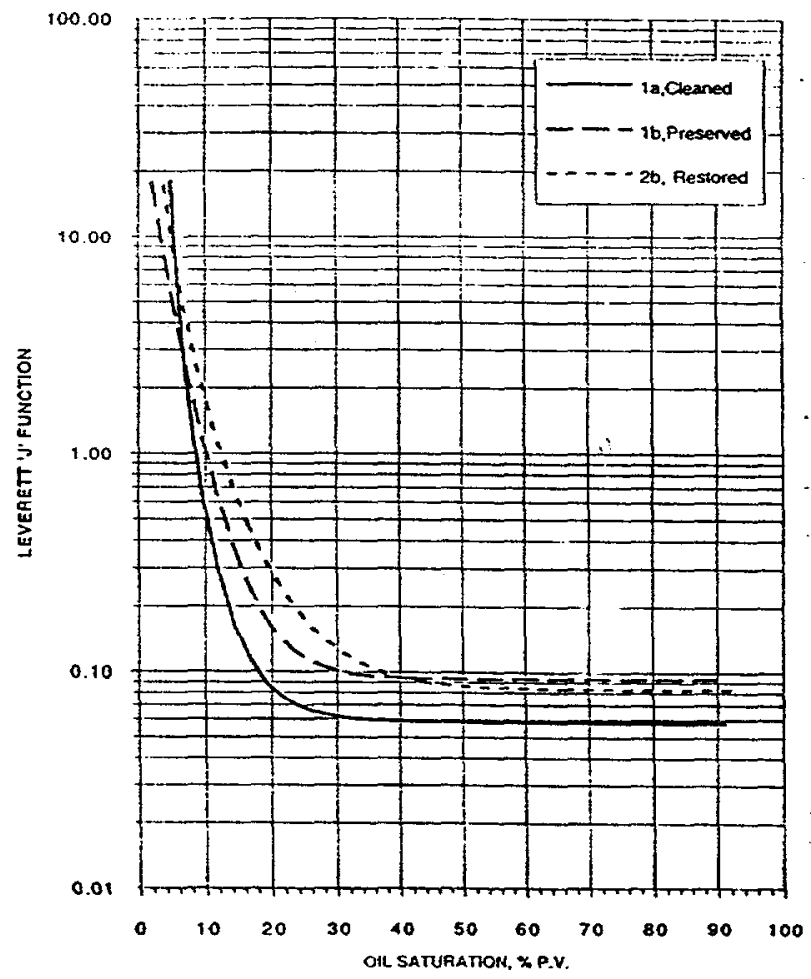

(B)

Figure 5.5. Brine - oil primary imbibition capillary pressure curves from elevated temperature, automated centrifuge data for Anasazi No. 6H-1 well. (A) capillary pressure, psi, and (B) capillary pressure curve, Leverett's J Function. 


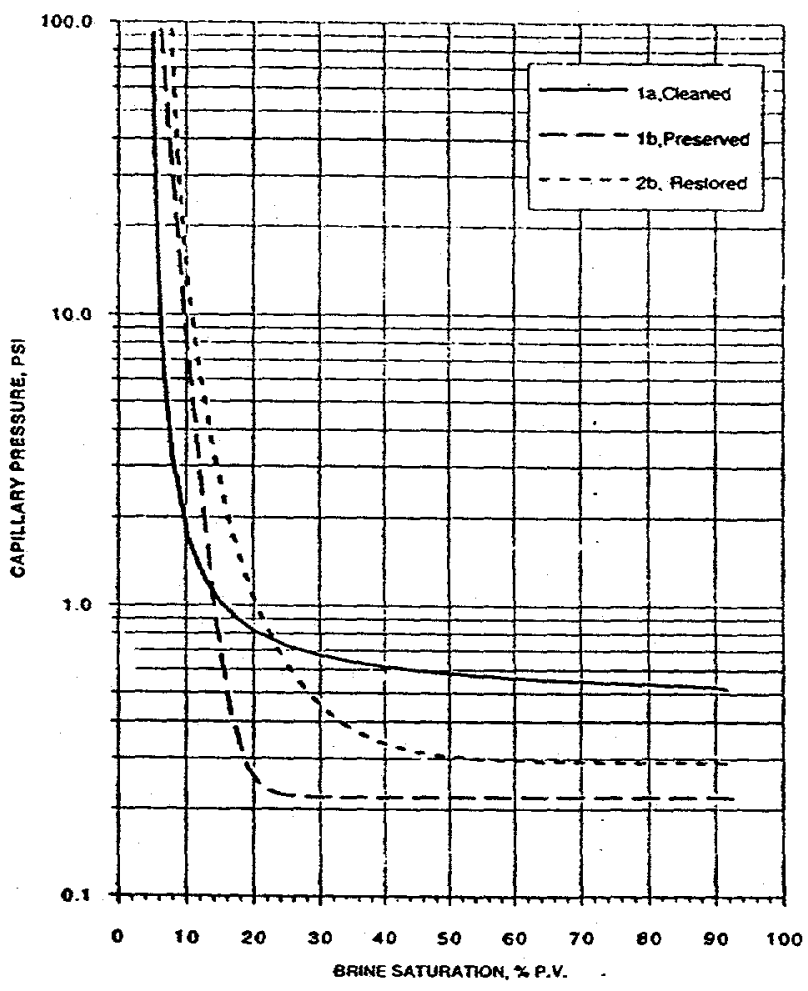

(A)

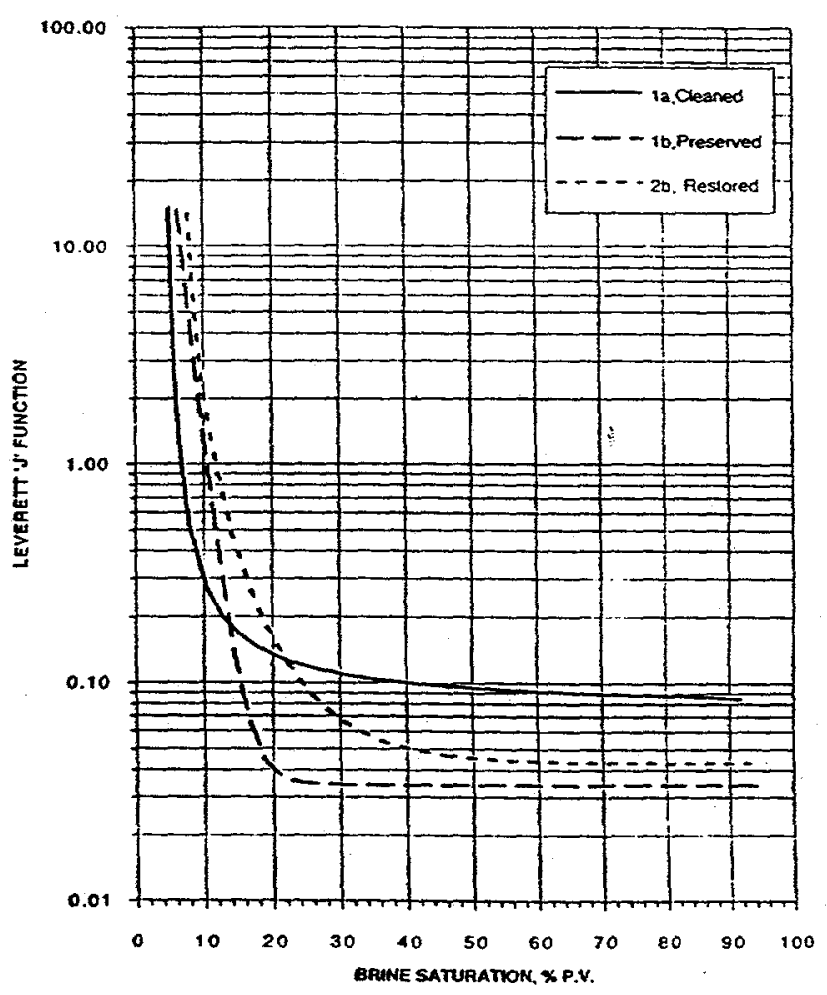

(B)

Figure 5.6. Oil - brine secondary drainage capillary pressure curves from elevated temperature, automated centrifuge data for Anasazi No. $6 \mathrm{H}-1$ well. (A) capillary pressure, psi, and (B) capillary pressure curve, Leverett's J Function. 


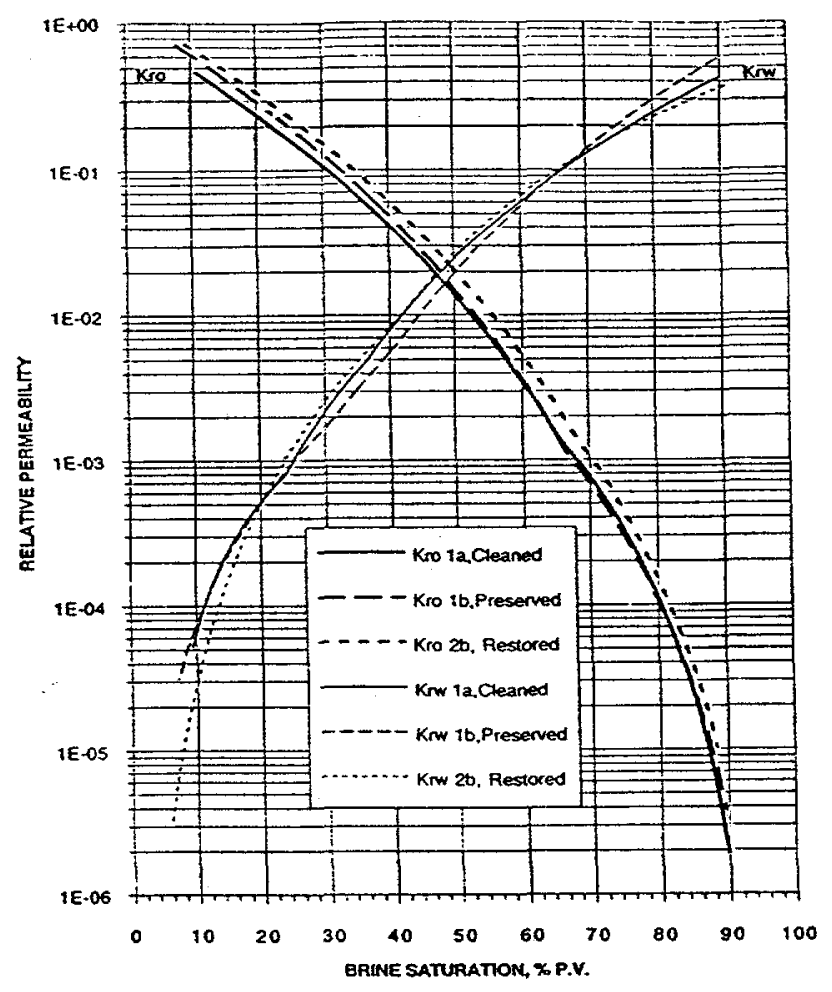

Figure 5.7. Oil - brine relative permeability curves from elevated temperature, automated centrifuge data for Anasazi No. 6H-1 well.

5.3.1.8 Oil/Brine Drainage Relative Permeability Test. Initial flowing brine permeabilities were measured and then a drainage capillary pressure experiment was conducted for use in wettability determination (figure 5.8). A comparison of the data is given in figure 5.7. The initial permeabilities were fixed to the measured flowing permeabilities and the data then history matched to produce the curves. The final oil saturations to which the curves are plotted is the final average saturation in the cores. This explains why the saturations are not as low as the capillary pressure final saturations which are the saturations calculated at the inflow end of the core.

5.3.1.9 Gas/Oil Capillary Pressure and Relative Permeability Experiment. A gas/oil drainage capillary pressure experiment was conducted. The data presented in figure 5.9 indicate the expected oil wetting in the presence of gas. The $\mathrm{S}_{\mathrm{or}}$ value between 0.8 and 2.5 percent is reflective of the lack of trapping sites in the core material. The slightly higher capillary entry pressure, when compared to the oil/brine system may be reflective of the non-equilibrium tension measurements used.

The samples were mounted in flow cells with an overburden pressure of 1,000 psi $(6,895$ $\mathrm{kpa})$ and heated to $130^{\circ} \mathrm{F}\left(54^{\circ} \mathrm{C}\right)$. Oil was then introduced and a fluid pressure of $500 \mathrm{psi}(3,448$ $\mathrm{kpa}$ ) maintained during resaturation and the effective oil permeability at irreducible water 


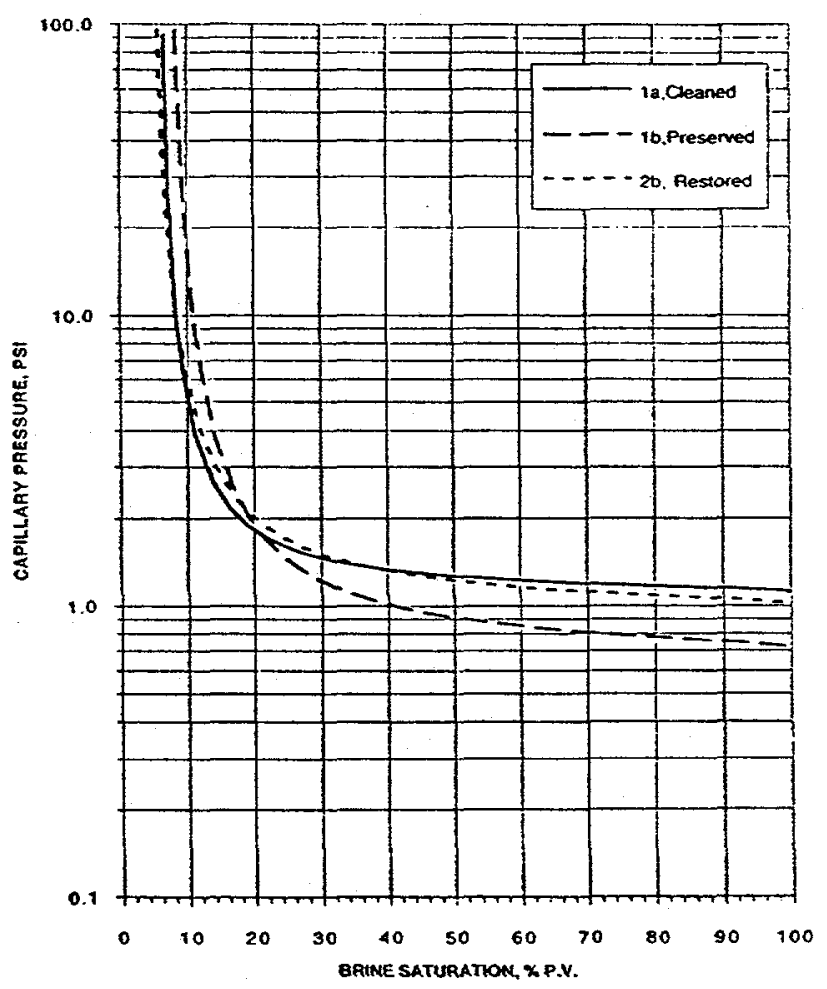

(A)

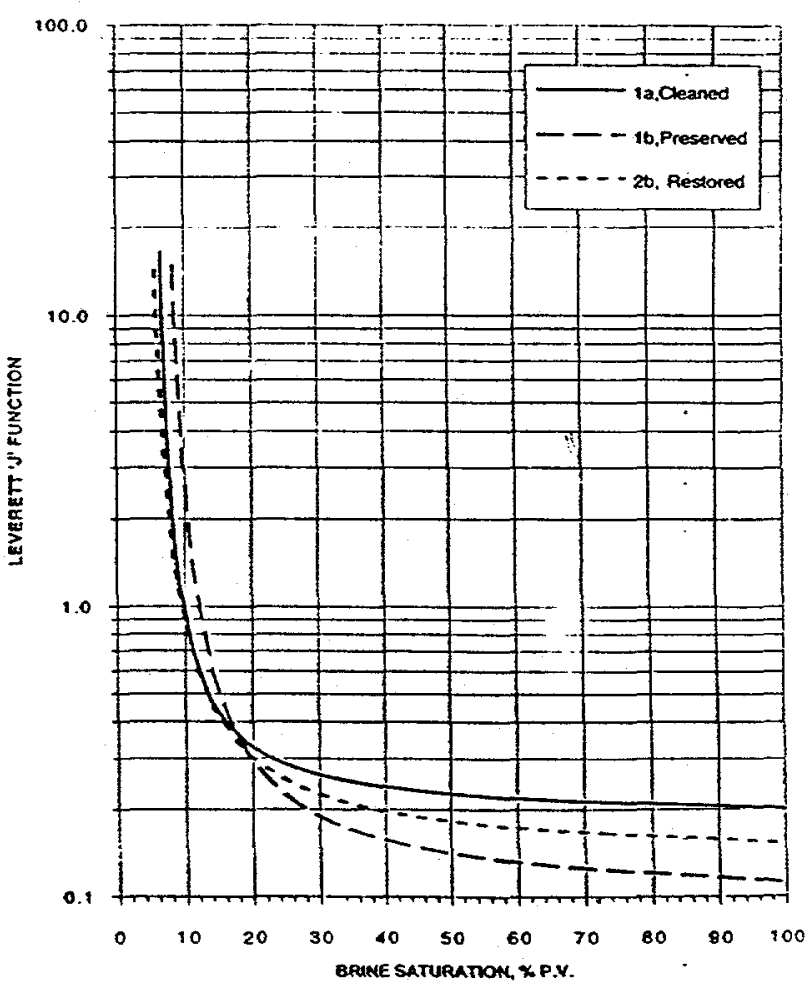

(B)

Figure 5.8. Oil - brine primary drainage capillary pressure curve from elevated temperature, automated centrifuge data for Anasazi No. 6H-1 well. (A) capillary pressure, psi, and (B) capillary pressure curve, Leverett's $J$ Function. 


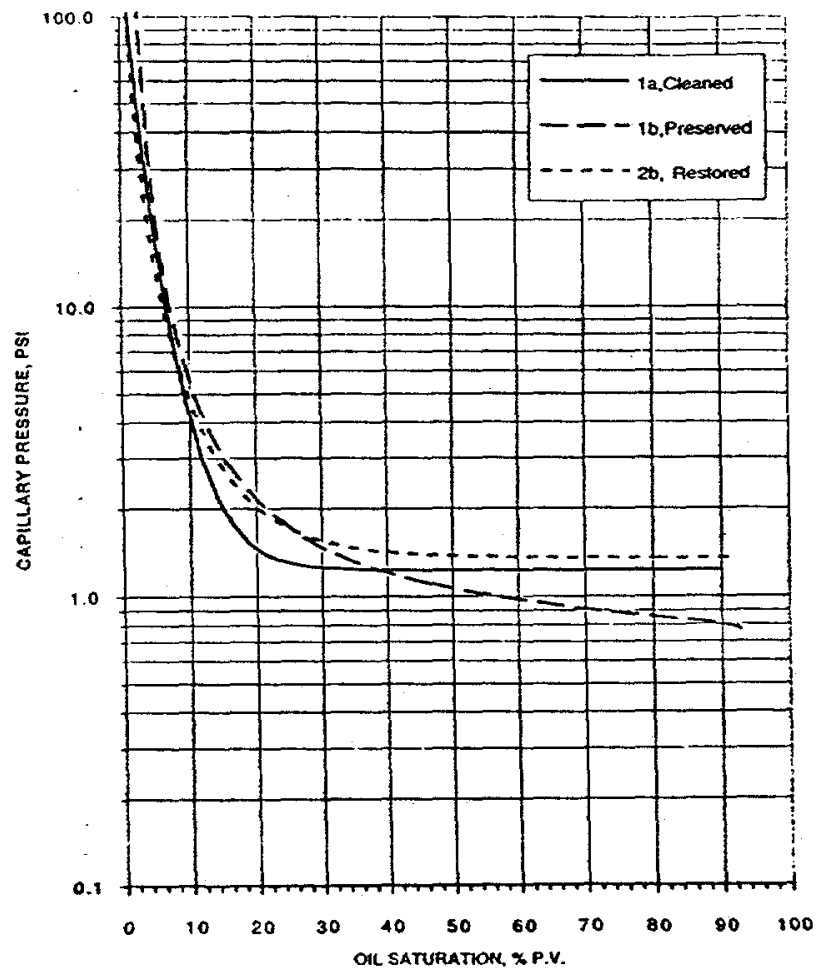

(A)

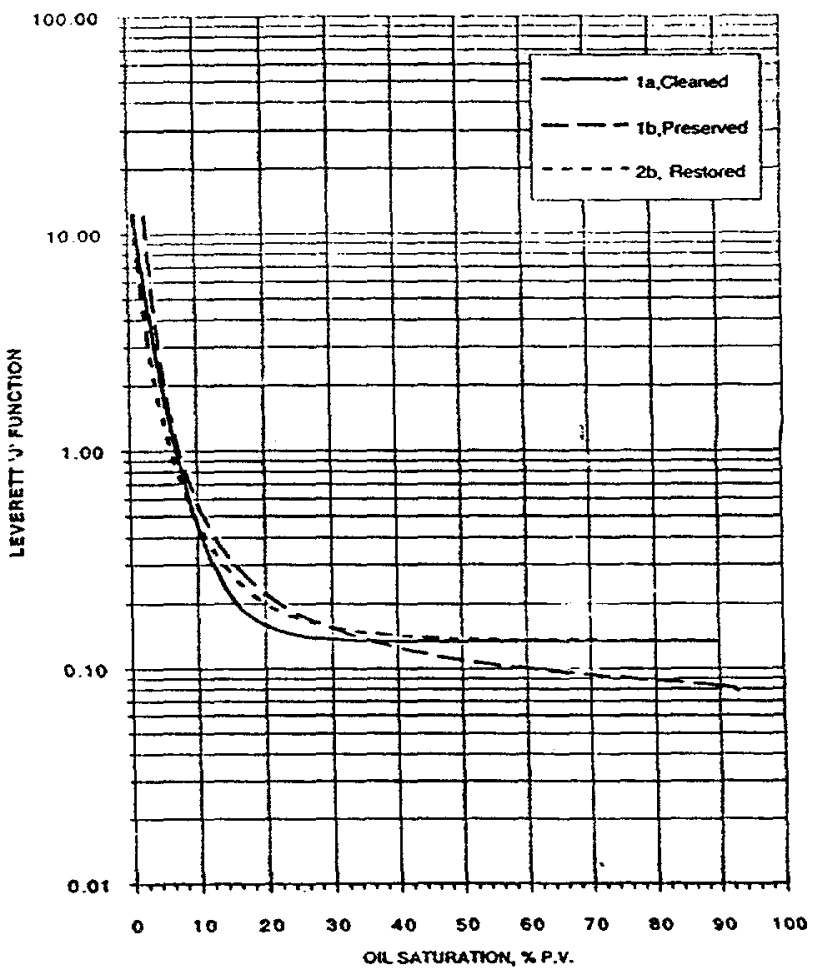

(B)

Figure 5.9. Gas - oil drainage capillary pressure curve from elevated temperature, automated centrifuge data for Anasazi No. 6H-1 well. (A) capillary pressure, psi, and (B) capillary pressure curve, Leverett's J Function. 
saturation $\left(\mathrm{K}_{\mathrm{e}}\right.$ at $\left.\mathrm{S}_{\mathrm{wr}}\right)$ measurements taken. The samples were cooled while maintaining the $500 \mathrm{psi}$ $(3,448 \mathrm{kpa})$ fluid pressure. The samples were then placed in the centrifuge drainage cells. The cells were heated to $130^{\circ} \mathrm{F}\left(54^{\circ} \mathrm{C}\right)$ and a single speed experiment was conducted to determine the gas/oil drainage relative permeability curves to oil presented in figure 5.10. The curves agree quite well to values of about $5 \times 10^{-4}$ at which point the cleaned core begins to deviate due in part at least to the inability of the bimodal model to fit the production data. At the conclusion of the experiment a gas permeability at $S_{o r}$ and $S_{w r}$ was measured and is presented in table 5.6.

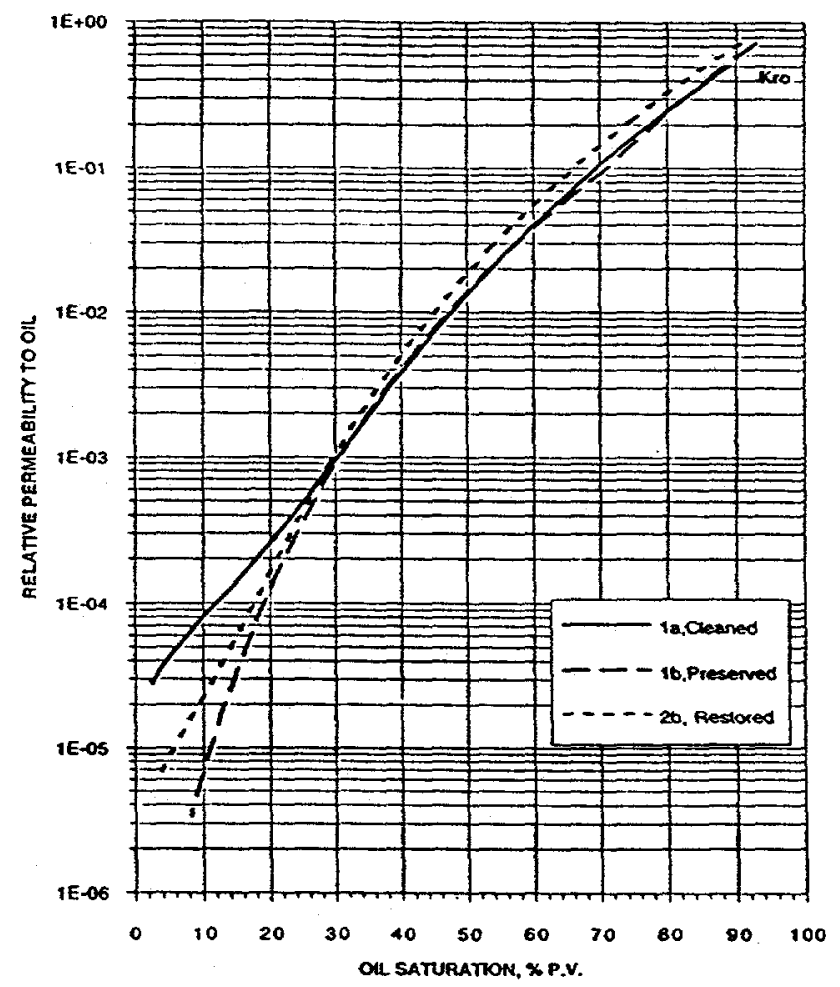

Figure 5.10. Gas - oil relative permeability curves from elevated temperature, automated centrifuge data for Anasazi No. $6 \mathrm{H}-1$ well. 
Table 5.6. Permeability and porosity data summary for the Anasazi No. 6H-1.

\begin{tabular}{|c|c|c|c|c|c|c|}
\hline Test No. o का & Core $1 \mathrm{a}$ & Core $1 b$ & Core 2 & Core $2 \mathrm{a}$ & Core $2 b$ & Core $4 a$ \\
\hline Depth $(f t)$ & 5691.210 & 5691.210 & 5691.460 & 5691.460 & 5691.460 & 5691.800 \\
\hline \multicolumn{7}{|l|}{ Initial Core Properties at 500 psi NCS } \\
\hline Length $(\mathrm{cm})$ & 4.097 & 4.252 & 9.073 & 4.470 & 4.257 & 4.262 \\
\hline Average Area $\left(\mathrm{cm}^{2}\right)$ & 11.158 & 11.159 & 11.187 & 11.194 & 11.194 & 11.153 \\
\hline Bulk Volume $(c c)$ & 45.716 & 47.447 & 101.502 & 50.044 & 47.652 & 47.534 \\
\hline Gas Pore Volume (cc) & 8.221 & 8.273 & 17.715 & 8.070 & 9.054 & 7.454 \\
\hline Grain Volume $(c c)$ & 37.495 & 39.174 & 83.787 & 41.974 & 38.598 & 40.080 \\
\hline Gas Porosity (\% Bulk volume) & 17.982 & 17.436 & 17.453 & 16.125 & 19.000 & 15.681 \\
\hline Grain Density (gm/cc) & 2.849 & 2.840 & 2.826 & 2.821 & 2.825 & 2.771 \\
\hline Gas Permeability (md) & 30.000 & 26.400 & 15.100 & 13.600 & 26.700 & 3.800 \\
\hline Oil Permeability No. 1 (md) & 12.950 & 20.710 & & & 18.420 & \\
\hline \multicolumn{7}{|l|}{ Core Properties at 2,000 psi NCS } \\
\hline Length $(\mathrm{cm})$ & 4.097 & 4.252 & 9.073 & 4.470 & 4.257 & 4.262 \\
\hline Average Area $\left(\mathrm{cm}^{2}\right)$ & 11.125 & 11.106 & 11.148 & 11.150 & 11.160 & 11.111 \\
\hline Bulk Volume (cc) & 45.578 & 47.224 & 101.149 & 49.847 & 47.509 & 47.355 \\
\hline Gas Pore Volume (cc) & 8.083 & 8.050 & 17.362 & 7.873 & 8.911 & 7.275 \\
\hline Gas Porosity (\% Bulk volume) & 17.735 & 17.046 & 17.165 & 15.794 & 18.756 & 15.362 \\
\hline Gas Permeability (md) & 26.500 & 23.100 & 13.200 & 12.300 & 24.400 & 2.900 \\
\hline $\begin{array}{l}\text { Brine Permeability } \\
\text { (as received) (md) }\end{array}$ & 10.400 & 8.300 & 4.300 & & & 1.000 \\
\hline $\begin{array}{l}\text { Brine Permeability } \\
\begin{array}{ll}\text { (at cleaning) } & \text { (md) }\end{array}\end{array}$ & 20.200 & & & & 13.800 & \\
\hline \multicolumn{7}{|l|}{ Centrifuge Values ${ }^{*}$} \\
\hline $\begin{array}{l}\text { Initial Residual Water Saturation } \\
\left(S_{w r}\right) \text { (in } S_{w} \% \text { Pore volume) }\end{array}$ & 8.990 & 10.240 & & & 7.950 & \\
\hline$K_{e o} @ S_{w i t}(m d)$ & 12.950 & 20.710 & & & 18.420 & \\
\hline $\begin{array}{l}\text { Residual Oil Saturation }\left(S_{\alpha}\right) \text { (in } \\
S_{0} \% \text { Pore volume) }\end{array}$ & 6.010 & 5.480 & & & 6.860 & \\
\hline $\begin{array}{l}\text { Water Saturation @ } S_{\alpha}\left(S_{w} @ S_{\alpha}\right) \\
\text { (in } S_{w} \% \text { Pore volume) }\end{array}$ & 93.990 & 94.520 & & & 93.140 & \\
\hline$K_{o w} @ S_{o r}(m d)$ & 16.400 & 16.800 & & & 10.900 & \\
\hline $\begin{array}{l}\text { Residual Water Saturation }\left(\mathrm{S}_{\mathrm{wr}}\right) \\
\text { (in } \mathrm{S}_{\mathrm{o}} \% \text { Pore volume) }\end{array}$ & 10.790 & 7.910 & & & 9.300 & \\
\hline$K_{e 0} @ S_{m+1}(m d)$ & 9.400 & 18.900 & & & 14.5 & \\
\hline
\end{tabular}


Table 5.6. (continued)

\begin{tabular}{|c|c|c|c|c|c|c|}
\hline 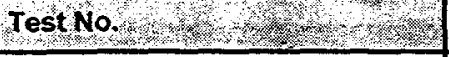 & Core $1 \mathrm{a}$ & core 1b & Core 2 & Core 2a & Core $2 \mathbf{b}$ & 3 core $4 a$ \\
\hline $\begin{array}{l}\text { Centrifuge Values } \\
\text { (continued) }\end{array}$ & & & & & & \\
\hline $\begin{array}{l}\text { Residual Oil Saturation } \mathrm{S}_{\mathrm{ox}} \text { (in } \\
\mathrm{S}_{0} \% \text { Pore volume) }\end{array}$ & 10.100 & 10.400 & & & 11.700 & \\
\hline $\begin{array}{l}\text { Water Saturation @ } S_{o r}\left(S_{w} @\right. \\
\left.S_{o r}\right) \text { (in } S_{w} \% \text { Pore volume) }\end{array}$ & 89.990 & 89.600 & & & 90.720 & \\
\hline$K_{\text {ew }} @ S_{\alpha}(m d)$ & 12.700 & 15.100 & & & 9.860 & \\
\hline $\begin{array}{l}\text { Final Residual Water Saturation } \\
\left(\mathrm{S}_{w}\right) \text { (in } \mathrm{S}_{w} \% \text { Pore volume) }\end{array}$ & 9.490 & 7.180 & & & 5.920 & \\
\hline$K_{e 0} @ S_{w t}(m d)$ & 15.220 & 19.180 & & & 19.370 & \\
\hline $\begin{array}{l}\text { Residual Oil Saturation }\left(\mathrm{S}_{\alpha}\right) \\
\text { (in } \mathrm{S}_{0} \% \text { Pore volume) }\end{array}$ & 2.410 & 8.220 & & & 3.220 & \\
\hline$K_{e g} \rightleftharpoons S_{o r}(m d)$ & 25.700 & 25.900 & & & 22.300 & \\
\hline Final Brine $100 \%$ saturated $(\mathrm{md})$ & 23.700 & 13.400 & & & 14.200 & \\
\hline
\end{tabular}

"Centrifuge cores

1a - cleaned

16 - preserved

$2 b$ - restored

**Effective gas permeability 
5.3.1.10 Final Saturation Determination via Dean-Stark. A Dean-Stark extraction was accomplished on the core material to determine the final oil and brine saturations, and to check the weight determined values used in the study. The material was then cleaned using a sequential solvent flow cleaning procedure involving: (1) a 3 percent potassium chloride brine to remove the precipitated salts from the extraction and (2) toluene and methanol flushes to properly clean the material.

5.3.1.11 Gas Property Measurements. Gas permeability and porosity measurements were made on the cleaned core material at 500 and $2,000 \mathrm{psi}(3,448$ and $13,790 \mathrm{kpa})$ net confining stress. The data are presented in table 5.6.

5.3.1.12 Saturation and $\mathbf{K}_{\mathrm{w}}$. The dry cores were weighted and then evacuated at which time degassed brine was introduced. The core holders were then pressurized to $2,000 \mathrm{psi}(13,790 \mathrm{kpa})$ and held for 16 hours at $73^{\circ} \mathrm{F}\left(23^{\circ} \mathrm{C}\right)$. The cores were removed from the cells and weighed. They were then placed in flow permeability cells with an overburden pressure of $1,000 \mathrm{psi}(6,895 \mathrm{kpa})$ and a fluid pressure of 500 psi $(3,448 \mathrm{kpa})$. Flow was established and when stabilized the absolute permeability of the water-saturated rock $\left(\mathrm{K}_{\mathrm{w}}\right)$ measurement was made (see table 5.6).

5.3.1.13 Primary Drainage Capillary Pressure Measurements. After the flowing permeability measurements, the samples were mounted in the centrifuge drainage cells, surrounded with crude oil, and heated to $130^{\circ} \mathrm{F}\left(54^{\circ} \mathrm{C}\right)$. Thirteen speed steps were used to define the capillary pressure curves. Each speed was maintained for eight hours before moving on to the next speed. The final average saturations were then extrapolated to infinite time using the production data and a Corey exponent of 2.5 for the extrapolation. The resultant average saturation curve was then converted to the capillary pressure curve at the inflow end of the core using a constrained Hassler-Brunner fit. The samples were cooled to $73^{\circ} \mathrm{F}\left(23^{\circ} \mathrm{C}\right)$ and weighed for saturation determinations. The resulting curves are seen in figure 5.8 and indicate a stronger water wetting nature than the secondary drainage curves seen in figure 5.6. This is evident from the higher Leverett " $\mathrm{J}$ " function entry pressure for the primary drainage curves. There appears to be a slight lowering in the entry pressure of the restored state core and an even lower value for the preserved core. This effect could be due to a surface oil adsorption which is time dependent and which requires stronger solvent cleaning than was accomplished using toluene and methanol.

5.3.1.14 U.S. Bureau of Mines and Amott Wettability Indices. Both the U.S. Bureau of Mines (USBM) and Amott wettability indices were determined from the primary waterflood and secondary oil flood capillary pressure experiments. The USBM index is the ratio of the areas under the two capillary pressure curves. The areas were calculated to a common pressure of $90 \mathrm{psi}(620 \mathrm{kpa})$. The results ranged in values from -0.33 to -0.49 . These values are commonly classified as mixed wet values with a slightly stronger oil than water wetting. The Amott results were the ratio of the production during the first speed step of the centrifuge divided by the total production during the experiment. This value is an upper limit for the "spontaneous" imbibition value since a slight amount of pressure was actually applied to the cores to produce the initial fluid. The values indicate no spontaneous water production and 6 to 25 percent spontaneous oil production. This spontaneous oil production was at an applied pressure of $0.6 \mathrm{psi}(4.1 \mathrm{kpa})$ while the water production values were taken at about $0.2 \mathrm{psi}(1.4 \mathrm{kpa})$ due to the difference in holder and sample configuration during the two experiments. If a spontaneous value for the oil production is calculated by extrapolating the 
curves to $0.2 \mathrm{psi}(1.4 \mathrm{kpa})$ the values all become zero as in the water production case. This would be consistent with the USBM results of mixed wettability. The higher entry pressure for the oil curves when compared to the water entry pressures on the preserved and restored cores support this favorable oil wetting as well.

5.3.1.15 Bond Number versus $S_{0 r} / S_{0 i}$. Figure 5.11 shows the relationship between the residual oil saturation to initial oil saturation $\left(\mathrm{S}_{\mathrm{or}} / \mathrm{S}_{\mathrm{oi}}\right)$ values versus the Bond Number for the waterflood capillary pressure experiments. The vertical lines are an artifact of the capillary entry pressure for the experiments. The remainder of the curves from about 10-7 to 10-5 show a film drainage mechanism common to thinning of oil films with increased pressure. The low residuals between 2 to 6 percent reflect the lack of trapping mentioned earlier.

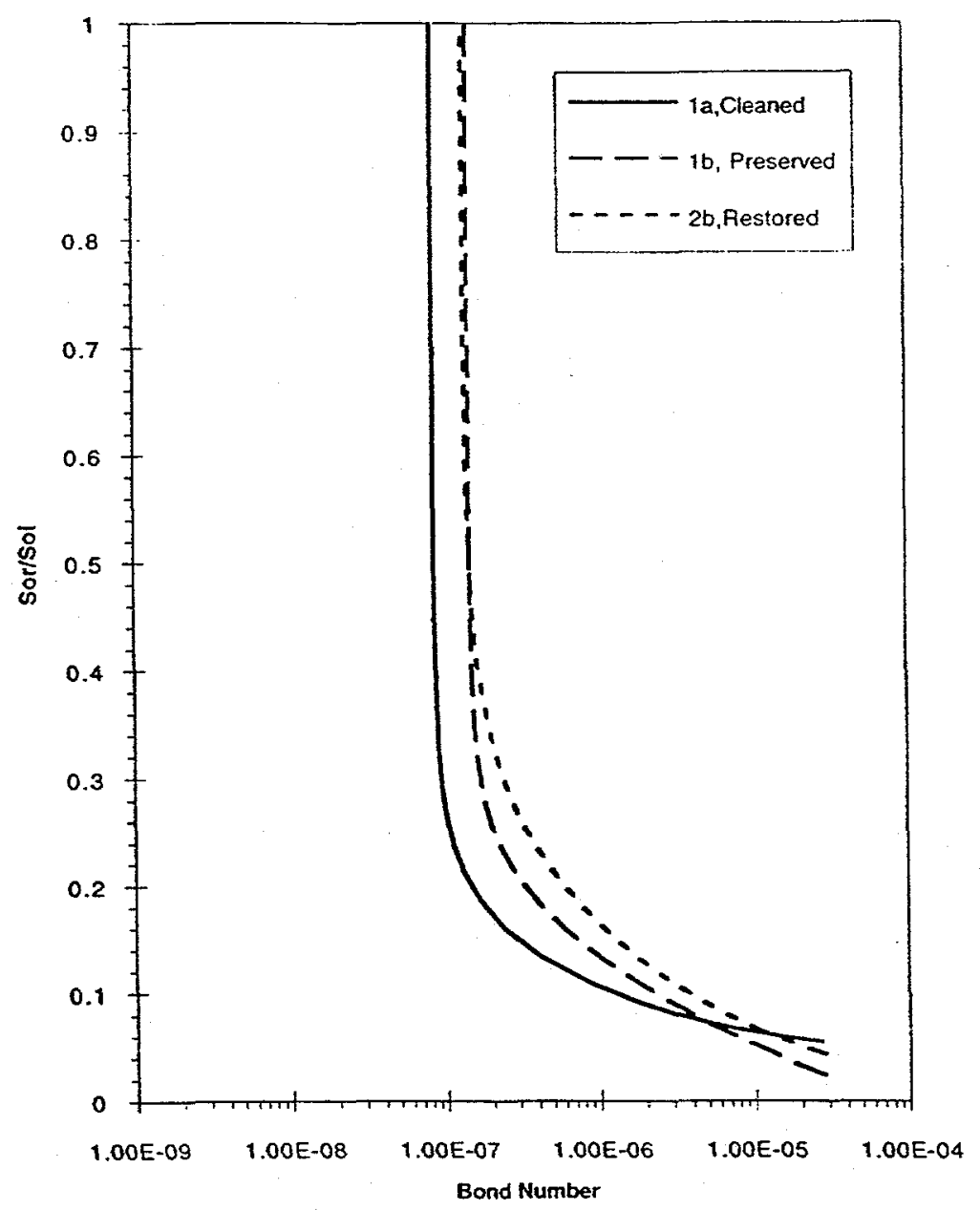

Figure 5.11. Bond number vs. $S_{o r} / S_{o i}$ curves from elevated temperature, automated centrifuge data for Anasazi No. 6H-1 well.

5.3.1.16 Summary. Centrifuge tests were performed on three core plugs to provide oil-brine and gas-oil capillary pressure and oil-brine and gas-oil relative permeability curves. The samples were 
prepared in three ways; core la was cleaned but not aged, core $1 \mathrm{~b}$ was preserved, and core $2 \mathrm{~b}$ was cleaned and aged to restore wettability. The tests were performed at $130^{\circ} \mathrm{F}\left(54^{\circ} \mathrm{C}\right)$ and the confining pressure of approximately $200 \mathrm{psi}(1,379 \mathrm{kpa})$ provided by shrinkable teflon jackets.

The data indicates a mixed wetting condition typical of carbonate systems with a slightly stronger oil wetting tendency in the preserved core and a nearly neutral wetting for the cleaned and unrestored core with the restored core falling between the others. The dominate feature of the cores is the lack of trapping sites yielding very low residuals in both the oil and brine phases. This feature overwhelms the slight differences in the wetting states of the core preparation techniques and yields capillary pressure and relative permeability curves that compare quite well.

\subsubsection{Rock Compressibility Measurements}

Compressibility testing was conducted on two carbonate samples obtained from the Anasazi Nos. 1 and $6 \mathrm{H}-1$ wells. The core material consisted of one sample of unpreserved limestone exhibiting vugular porosity from the Anasazi No. 1 well, and one unpreserved microporous dolomite sample from the Anasazi No. $6 \mathrm{H}-1$ well.

Compressibility of a porous medium is defined as the relative volume change due to a unit change in applied stress. Three types of compressibilities consisting of the bulk compressibility $\left(\mathrm{C}_{b}\right)$, the solid (grain) compressibility $\left(\mathrm{C}_{g}\right)$, and the pore volume compressibility $\left(\mathrm{C}_{p}\right)$, were determined for both carbonate samples. The bulk compressibility represents the relative changes in bulk volume of the medium; the grain compressibility represents the relative volumetric change of the solid portion of the medium; and the pore volume compressibility represents the relative change in pore volume. The sample depth, pre-test bulk density, effective grain density, and effective porosity for both samples are presented in table 5.7. In addition to the compressibility determinations, each specimen was loaded under triaxial conditions for determination of quasi-static elastic moduli and Poisson's ratio.

Table 5.7. Pre-test sample conditions and physical properties for selected samples from the Anasazi Nos. 1 and $6 \mathrm{H}-1$ wells.

\begin{tabular}{|c|c|c|c|c|c|c|c|c|}
\hline \multirow{2}{*}{$\begin{array}{l}\text { Sample } \\
\text { Depth } \\
\text { (ft) }\end{array}$} & \multirow{2}{*}{$\begin{array}{l}\text { Rock } \\
\text { Type }\end{array}$} & \multirow{2}{*}{$\begin{array}{l}\text { Length } \\
\text { (in) }\end{array}$} & \multirow{2}{*}{$\begin{array}{l}\text { Diameter } \\
\text { (in) }\end{array}$} & \multicolumn{3}{|c|}{ Pre-Test Density (gm/cm3) } & \multirow{2}{*}{$\begin{array}{l}\text { Porosity } \\
(\%)\end{array}$} & \multirow{2}{*}{$\begin{array}{l}\text { Permeability } \\
\text { to Gas (mid) }\end{array}$} \\
\hline & & & & $\begin{array}{c}\text { Saturated } \\
\text { Bulk }\end{array}$ & $\begin{array}{l}\text { Dry } \\
\text { Bulk }\end{array}$ & Grain & & \\
\hline $\begin{array}{c}5,648.5 \\
- \\
5,648.9\end{array}$ & $\begin{array}{c}\text { Limestone } \\
\text { (Anasazi } \\
\text { No. } 1 \\
\text { Well) }\end{array}$ & 3.724 & 1.998 & 2.390 & 2.244 & 2.698 & 16.83 & 51.45 \\
\hline $\begin{array}{c}5,692.0- \\
5,692.4\end{array}$ & $\begin{array}{c}\text { Dolomite } \\
\text { (Anasazi } \\
\text { No. } 6 \mathrm{H}-1 \\
\text { Well) }\end{array}$ & 3.881 & 1.997 & 2.588 & 2.487 & 2.814 & 11.62 & 0.65 \\
\hline
\end{tabular}

* Effective grain density and porosity determined - reflects only interconnected pore space 
Simulated in-situ conditions were used for the compressibility and triaxial compression tests. The testing scenario was based on an approximate average horizontal stress gradient of 0.65 pounds per square inch per foot (psi/ft [15 kpa/m]), a reservoir pore pressure of 2,000 psi $(13,790 \mathrm{kpa})$, and a vertical stress gradient of $1 \mathrm{psi} / \mathrm{ft}(23 \mathrm{kpa} / \mathrm{m})$ (overburden stress). The target in-situ pressures for this test program are shown in table 5.8.

Table 5.8. Target pressures for simulated in-situ conditions.

\begin{tabular}{|l|c|c|c|c|c|}
\hline Rock Type & $\begin{array}{c}\text { Depth } \\
\text { (ft) }\end{array}$ & $\begin{array}{c}\text { Target Confining } \\
\text { Pressure (psi) }\end{array}$ & $\begin{array}{c}\text { Target Pore } \\
\text { Pressure (psi) }\end{array}$ & $\begin{array}{c}\text { Target Stress } \\
\text { Difference (psi) }\end{array}$ & $\begin{array}{c}\text { Axial Stress } \\
\text { (psi) }\end{array}$ \\
\hline Limestone & $5,648.5-.9$ & 3,670 & 2,000 & 1,980 & 5,650 \\
\hline Dolomite & $4,592.0-.4$ & 3,700 & 2,000 & 1,990 & 5,690 \\
\hline
\end{tabular}

TerraTek, Inc. (1995) presents details on sample preparation and testing conditions. Table 5.9 presents the compressibility and Biot's coefficient under hydrostatic stress conditions. Table 5.10 presents the quasi-static mechanical properties determined from the triaxial compression segment of the compressibility tests. Table 5.11 presents the compressibilities determined under uniaxial strain conditions. Both the bulk compressibility (defined under uniaxial strain boundary conditions as the axial compaction coefficient $\left.\left[\mathrm{C}_{b p}^{u}\right]\right)$ and pore volume compressibilities $\left(\mathrm{C}_{p p}^{u}\right)$ are provided in table 5.11. The pore pressure range from which the compressibilities were calculated are also included in table 5.11 .

Table 5.9. Compressibilities determined from hydrostatic compression for samples from the Anasazi Nos. 1 and $6 \mathrm{H}-1$ wells.

\begin{tabular}{|c|c|c|c|c|c|c|}
\hline $\begin{array}{l}\text { Sample } \\
\text { Depth } \\
\text { (ft) }\end{array}$ & $\begin{array}{l}\text { Rock } \\
\text { Type }\end{array}$ & $\begin{array}{c}\text { Stress Range } \\
\text { (psi) }\end{array}$ & $\begin{array}{c}\text { Grain } \\
\text { Compressibility } \\
\left(10^{-5} \text { psi }^{-1}\right)\end{array}$ & $\begin{array}{c}\text { Bulk } \\
\text { Compressibility } \\
\left(10^{\circ} \mathrm{psi}^{-1}\right)\end{array}$ & $\begin{array}{c}\text { Pore Volume } \\
\text { Compressibility } \\
\left(10^{-5} \mathrm{psi}\right)\end{array}$ & $\begin{array}{c}\text { Biot's } \\
\text { Constant } \\
\alpha\end{array}$ \\
\hline \multirow{4}{*}{$\begin{array}{r}5,648.5 \\
-5,648.9\end{array}$} & \multirow{4}{*}{$\begin{array}{c}\text { Limestone } \\
\text { (Anasazi } \\
\text { No. } 1 \\
\text { Well) }\end{array}$} & 60 to 320 & & 21.593 & 12.830 & 0.998 \\
\hline & & 525 to 1,956 & 5.1203 & & & \\
\hline & & 2,243 to 2,807 & & 4.0396 & 2.4002 & 0.987 \\
\hline & & 3,083 to 3,636 & & 1.7226 & 1.0235 & 0.970 \\
\hline \multirow{4}{*}{$\begin{array}{c}5,692.0 \\
-5,692.4\end{array}$} & \multirow{4}{*}{$\begin{array}{c}\text { Dolomite } \\
\text { (Anasazi } \\
\text { No. } 6 \mathrm{H}-1 \\
\text { Well) }\end{array}$} & 75 to 315 & & 1.6797 & 1.4468 & 0.994 \\
\hline & & 547 to 1,805 & 1.0400 & & & \\
\hline & & 2,368 to 2,910 & & 1.7074 & 1.4706 & 0.994 \\
\hline & & 3,050 to 3,690 & & 1.2950 & 1.1154 & 0.992 \\
\hline
\end{tabular}


Table 5.10. Quasi-static mechanical properties determined from triaxial compression for samples from the Anasazi Nos. 1 and $6 \mathrm{H}-1$ wells.

\begin{tabular}{|c|c|c|c|c|c|c|}
\hline \multirow{2}{*}{$\begin{array}{l}\text { Sample } \\
\text { Depth }(\mathrm{ft})\end{array}$} & \multirow{2}{*}{ Rock Type } & \multirow{2}{*}{\multicolumn{2}{|c|}{$\begin{array}{l}\text { Axial Stress bifference Range for } \\
\text { Properties Calculations (psi) }\end{array}$}} & \multicolumn{3}{|c|}{ Triaxial Compression Moduli $\left(10^{\circ} \mathrm{psi}\right.$} \\
\hline & & & & Young s & Bunkstive & hean \\
\hline $5,648.5-.9$ & Limestone & 610 to 1,390 & 0.20 & 2.37 & 1.30 & 0.99 \\
\hline $5,692.0-.4$ & Dolomite & 605 to 1,390 & 0.15 & 3.21 & 1.51 & 1.40 \\
\hline
\end{tabular}

Table 5.11. Parameters determined during uniaxial strain/pore pressure drawdown segment.

\begin{tabular}{|c|c|c|c|c|}
\hline $\begin{array}{l}\text { Sample } \\
\text { Depth (ft) }\end{array}$ & $\begin{array}{l}\text { Rock } \\
\text { TYpe }\end{array}$ & $\begin{array}{l}\text { Pore Pressure } \\
\text { Stress Range(psi) }\end{array}$ & $\begin{array}{c}\text { Compaction Coefficient } \\
\left(\mathrm{C}_{\mathrm{B}}, 10^{-7} \mathrm{psi}\right)\end{array}$ & $\begin{array}{l}\text { Pore Volume Compressibility } \\
\left(C_{\mathrm{p}}^{4} 10^{6} \mathrm{f} \text { psi) }\right.\end{array}$ \\
\hline $5,648.5-.9$ & Limestone & 1,935 to 300 & 3.9263 & 2.3329 \\
\hline $5,692.0-.4$ & Dolomite & 1,915 to 275 & 3.6977 & 3.1849 \\
\hline
\end{tabular}

\subsection{References}

Bourdet, D, 1985, Pressure behavior of layered reservoirs with crossflow: Society of Petroleum Engineers Technical Paper 13628, California Regional Meeting, Bakersfield, CA, p. 405416.

D.B. Robinson Research Ltd., 1995, Laboratory PVT program for Harken Energy reservoir fluid phase 1:- Unpublished report for REGA Inc., DBRR file 205136, 44 p.

Hirasaki, G.J., Rohan, J.A., and Dubey, S.T., 1990, Wettability evaluation during restored-state core analysis: Society of Petroleum Engineers Technical Paper 20506, 65th Annual Technical Conference and Exhibition, Production Operations and Engineering Volume, p. 361-375.

TerraTek, Inc., 1995, Compressibility of carbonate from the Anasazi No. 1 and No. 6H-1 wells: Unpublished report for REGA Inc., no. TR96-23, 20 p.

Westport Technology Center International, 1995, Harken Energy special core analysis - Anasazi 6H: Unpublished report for Harken Energy Corporation, no. WTCI95-201, 76 p. 


\title{
6. MECHANISTIC RESERVOIR SIMULATION STUDIES
}

\author{
W.E. Culham \\ REGA Inc.
}

\subsection{Introduction}

To provide some initial insight into the basic production mechanism of the Anasazi reservoir some simple one- and two-dimensional compositional simulation studies were conducted prior to developing final reservoir description models and the final three-dimensional simulation study. In addition to gaining insight into possible production mechanisms, the simulation studies were used to estimate a fluid bubble point pressure that might be realized if the reservoir was re-pressured after producing the current volumes of oil and gas. This bubble point data was used for preparing fluid samples for $\mathrm{CO}_{2}$ swelling tests discussed in the previous section.

\subsection{Model Description}

The bulk volume of the reservoir required to roughly match observed pressure-production conditions was established with a series of one-dimensional simulation runs that adjusted reservoir bulk volume until a reasonable match of observed production data (GOR) was obtained. This volume was used to guide the overall volume of the two-dimensional model $(2,500$ feet $X 2,500$ feet X 100 feet [762 m X $762 \mathrm{~m} \mathrm{X} 30 \mathrm{~m}]$ - Anasazi reservoir units only).

The geologic model was a simplistic two-layer model consisting of a dolomite unit and a limestone unit. The homogeneous layers were assigned an average Anasazi thickness of 70 feet (21 $\mathrm{m})$ and 30 feet $(9 \mathrm{~m})$ for the dolomite and limestone units respectively. Several simulation runs were used to arrive at an overall vertical to horizontal permeability $\left(\mathrm{k}_{\mathrm{v}} / \mathrm{k}_{\mathrm{h}}\right)$ ratio of 0.02 . This gave the best GOR match of ratios investigated. The dolomite unit was assigned a uniform lateral permeability of $10.0 \mathrm{md}$ and a vertical permeability of $0.2 \mathrm{md}$ using the $\mathrm{k}_{\mathrm{v}} / \mathrm{k}_{\mathrm{h}}=0.02$. The limestone unit, at the base of the Desert Creek zone, was assigned a uniform lateral permeability of $200 \mathrm{md}$ and a vertical permeability of $4.0 \mathrm{md}$. The average uniform porosities assigned the dolomite and limestone units were 10.4 percent and 9.0 percent respectively. An initial oil saturation of 0.85 and an initial irreducible water saturation of 0.15 was used. The initial pressure was set to 2,260 psia $(15,583$ $\mathrm{kpa}$ ). The Anasazi reservoir system results are used to illustrate the findings. The numerical grid was $200 \mathrm{x}$-direction blocks, one y-direction block, and $20 \mathrm{z}$-direction blocks. Each geologic unit was assigned 10 layers.

\subsection{Fluid Properties and Production Data}

A equation of state was calibrated using black oil PVT data from the Anasazi reservoir and the Jack reservoir fluid properties study was used to provide $\mathrm{C} 7+$ characterization. A nine pseudo component representation of the fluid was developed which provided a good match of volumetric fluid property data available from the Anasazi reservoir fluid study. The calibrated equation of state was used in the compositional simulation to conduct the simple mechanistic reservoir studies. 
As discussed earlier, the actual well by well, and thus field production data, was set up in data files formatted for comparison with simulation production results. The actual historic monthly production data was used as input to the simulation during the history match phase.

\subsection{Stimulation Study Procedure}

The simplistic two-dimensional models and compositional simulation were used to history match the production performance of the Anasazi reservoir through March 1995. The main parameter investigated was the overall vertical to lateral permeability ratio and the degree of communication between the dolomite and limestone units. A qualitative match rather than a detailed match was used for assessing the results.

\subsection{Study Results}

The first result of note was that to provide a reasonable match of reservoir response, particularly during the liquid expansion phase of production an initial oil-in-place value of 8.2 million stock tank barrels (MMSTB [1.3 million $\left.\mathrm{m}^{3}\right]$ ) was needed. This compares to an approximate volumetric value of 5.3 MMSTB $\left(0.8\right.$ million $\left.\mathrm{m}^{3}\right)$. The oil in place needed to support the correct

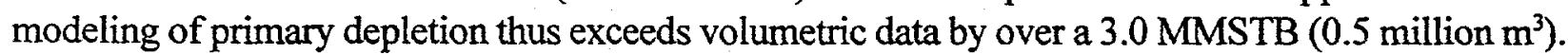
Future full three-dimensional studies will be used to identify the basis for this difference.

Simulation results for the $k_{v} / k_{h}=0.02$ case results for the Anasazi reservoir are presented in figures 6.1 and 6.2. Figure 6.1A presents field oil production for the Anasazi reservoir versus time. This data was used as input to the model via single well monthly oil rate specifications. Figures 6.1B and $6.1 \mathrm{C}$ present the simulation production versus the observed field gas production rate and the GOR (predicted value represented by solid line and historic data by + symbol). The match between predicted and observed data is considered reasonable, given the simplicity of the twodimensional geologic model, for understanding basic reservoir production mechanisms. The initial constant GOR period, representing the liquid expansion portions of the depletion, is well matched. The rate of GOR increase and ultimately leveling off is reflecting fluid migration between the dolomite/limestone intervals and gas segregation via gravity facies. The gas segregation after 1,461 days of production clearly shows in figure 6.2. This figure shows higher gas saturation buildups at the top of the dolomite (layer 1) and top of the limestone (layer 11).

Figure 6.1D illustrates the average reservoir pressure decline to the current expected value of 400 to $500 \mathrm{psi}(2,758-3,448 \mathrm{kpa})$. Figures $6.1 \mathrm{E}$ and $6.1 \mathrm{~F}$ present oil production and oil in place from and in the two geologic units respectively. Figure $6.1 \mathrm{E}$ shows that over 90 percent of the production comes from the limestone interval. However, figure 6.1F illustrates that despite the major portion of production being from the limestone interval there is not a corresponding decrease in the oil in place in the limestone interval. This behavior clearly supports the gravity drainage of oil from the upper dolomite interval into the lower limestone interval from which the producing wells major share of production arises (figure 6.1E). Using this qualitative assessment prompted further analysis and since the simulator provides data that summarizes the flow of oil between the dolomite and limestone intervals, it was possible to determine the ratio of this flow to the limestone production. Figure 6.3 shows the various fluid rates (in bbls of oil per month [BOPM]) used in the 


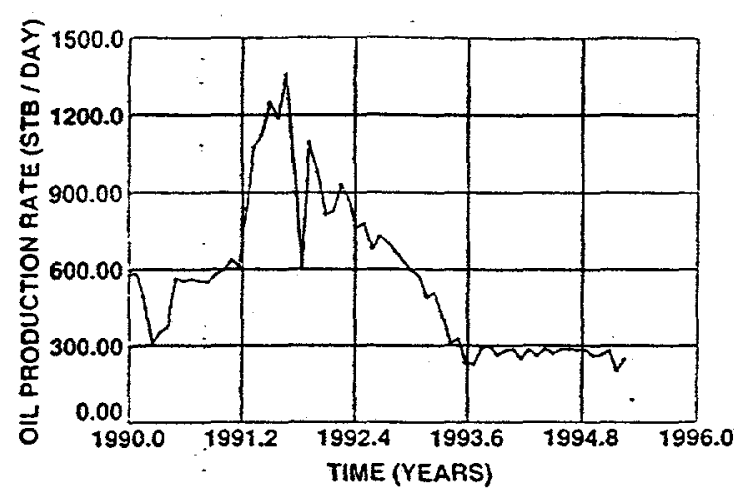

(A)

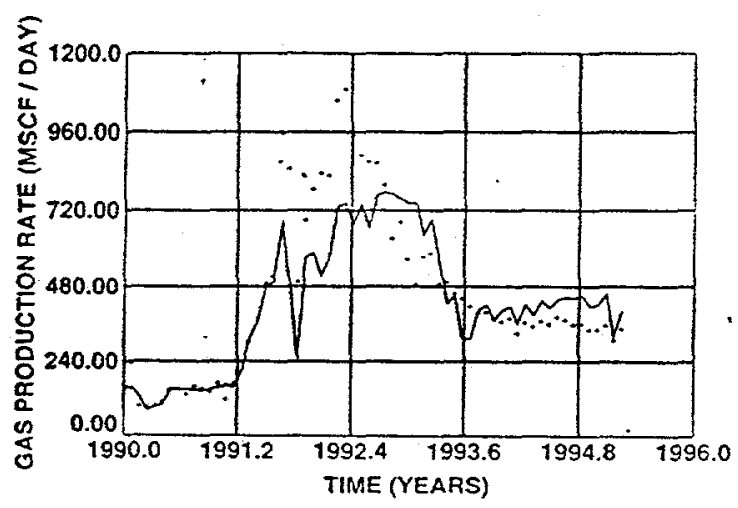

(B)

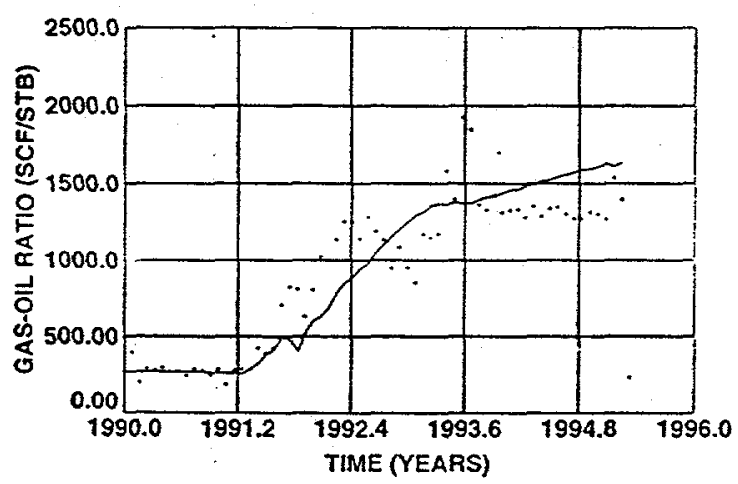

(C)

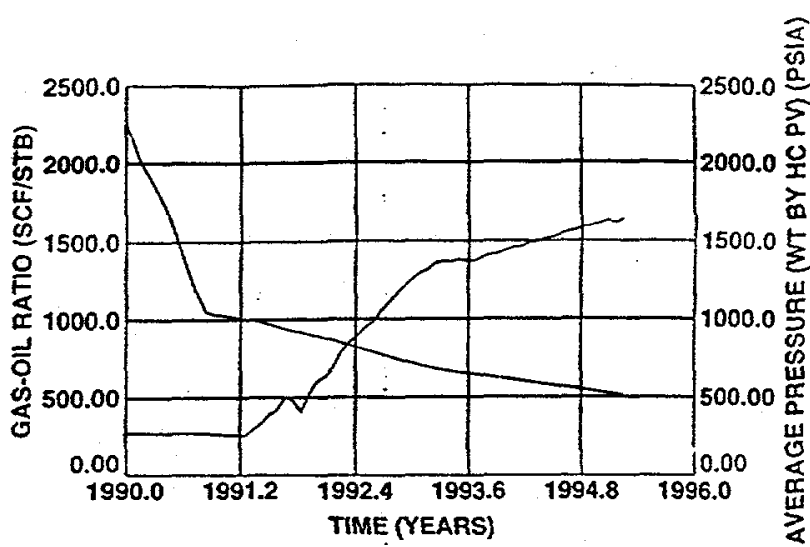

(D)

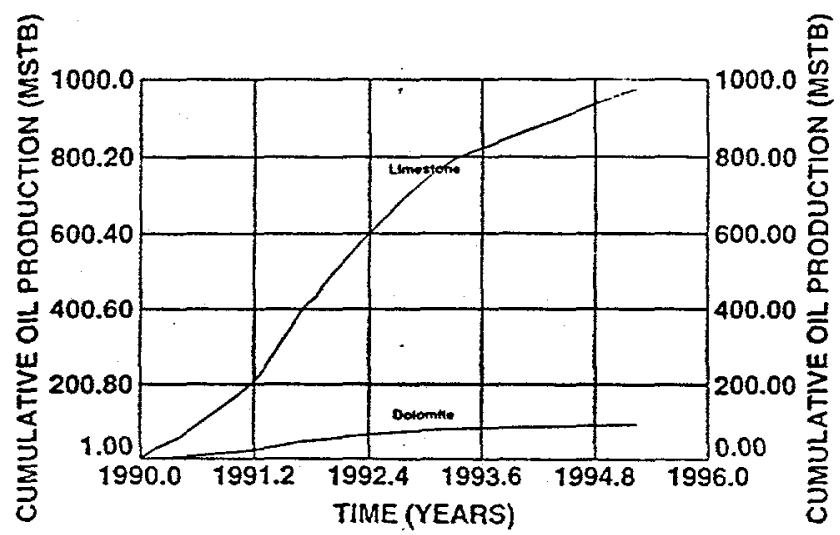

(E)

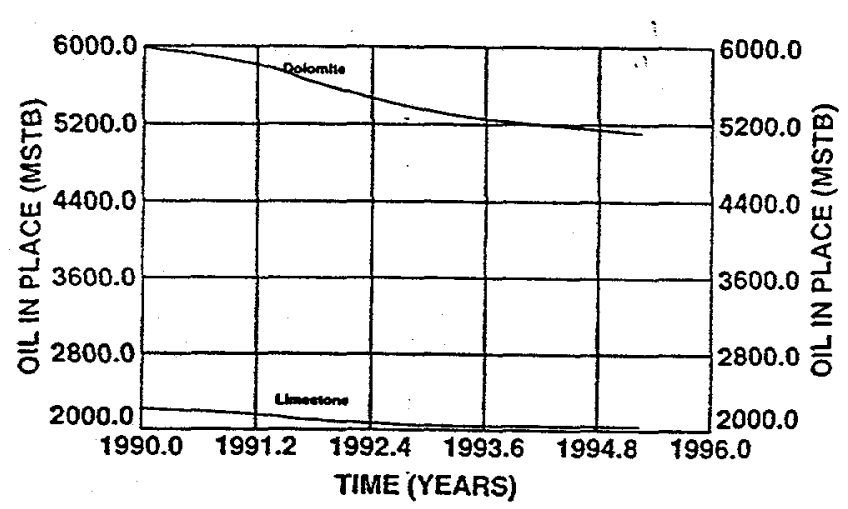

(F)

Figure 6.1. Results of two-dimensional reservoir simulation of the Anasazi field ( $k_{\mathrm{v}} / \mathrm{k}_{\mathrm{h}}$ ratio $=0.02$ ). (A) historic oil production rate vs. time, (B) predicted vs. actual gas production data, (C) predicted vs. actual GORs, (D) predicted GOR and reservoir pressure vs. time, (E) predicted limestone and dolomite oil production vs. time, and (F) predicted limestone and dolomite oil-in-place variation with time. 
$10 \quad 20 \quad 30 \quad 40 \quad 50 \quad 60 \quad 70 \quad 80 \quad 90100110120130140150160170180190200$

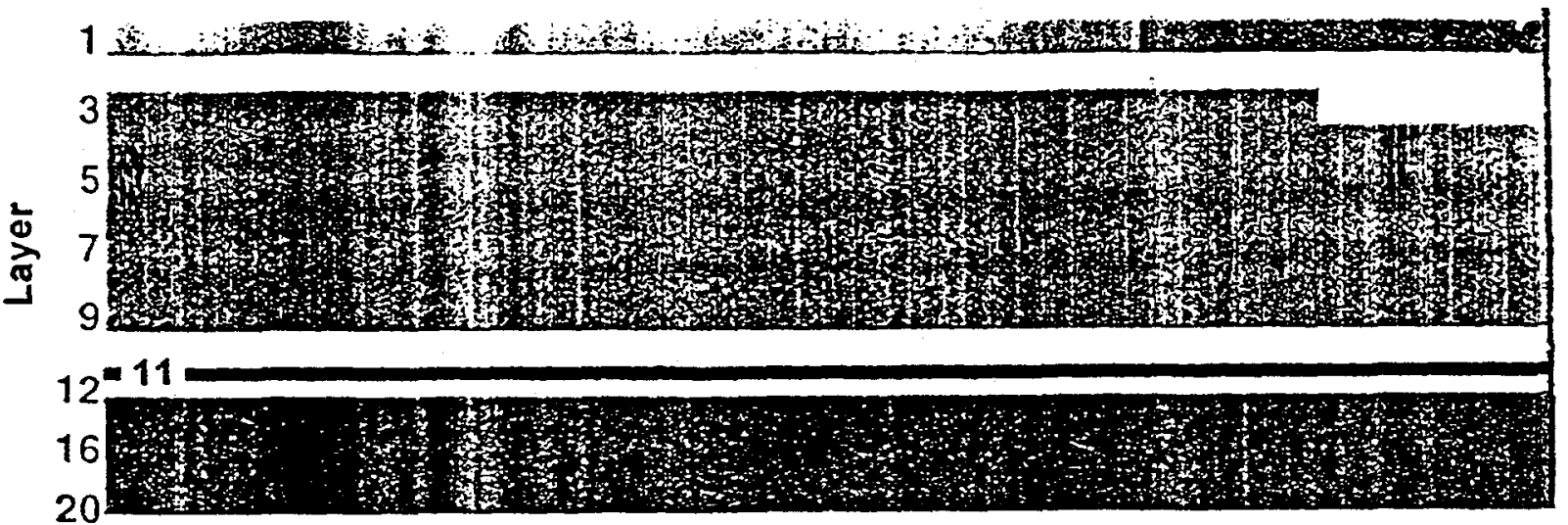

Distance (ft)

\section{SHUT-IN}

FRONT $X Z$ PLANE FOR $Y=1$

0.0

GAS SATURATION (FRACTION)

0.385

Figure 6.2. Two-dimensional reservoir simulation of the Anasazi field showing gas saturation for $\mathrm{XZ}$ plane after 1,461 days of production at January $1,1994$.

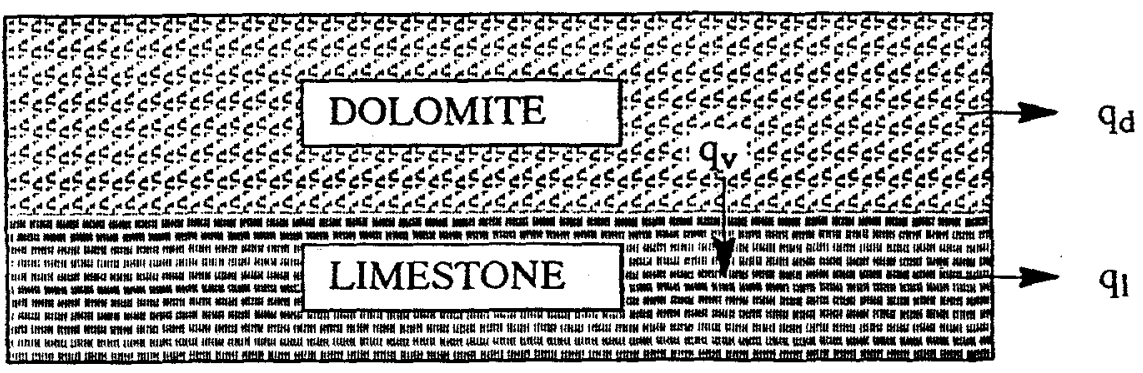

Figure 6.3. Schematic reservoir simulator model of the Anasazi reservoir. Arrows indicate fluid-flow directions. 
analysis, where $\mathrm{q}_{\mathrm{d}}$ and $\mathrm{q}_{\mathrm{l}}$ are dolomite and limestone production respectively at the well, and $\mathrm{q}_{\mathrm{v}}$ is vertical flow from the dolomite interval (supra-mound) to the limestone interval (mound core). Table 6.1 provides specific data on the relation of gravity-drained oil into the limestone interval versus actual limestone interval production.

Table 6.1. Analysis of gravity drainage behavior.

\begin{tabular}{|c|c|c|c|c|}
\hline Month Ending & 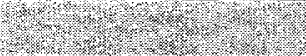 & (2) Flui & Rates & (1) \\
\hline (1) & $q_{j} \cdot \mathrm{BOPM}$ & 9, BOPM & 9. BOPM & $q_{,}, q_{1}$ \\
\hline $1 / 31 / 90$ & $1,889.70$ & $16,121.30$ & $11,069.10$ & 0.687 \\
\hline $6 / 30 / 90$ & $1,787.00$ & $15,222.90$ & $10,553.60$ & 0.693 \\
\hline $1 / 31 / 91$ & $2,101.50$ & $17,642.00$ & $12,515.90$ & 0.709 \\
\hline $6 / 30 / 91$ & $3,826.00$ & $33,645.90$ & $24,458.20$ & 0.727 \\
\hline $1 / 31 / 92$ & $2,196.00$ & $23,041.20$ & $19,755.10$ & 0.857 \\
\hline $6 / 30 / 92$ & 1.910 .30 & $21,461.60$ & $17,970.10$ & 0.837 \\
\hline $1 / 31 / 93$ & $1,333.20$ & $16,462.20$ & $14,003.10$ & 0.851 \\
\hline $6 / 30 / 93$ & 683.70 & $9,127.00$ & $9,310.00$ & 1.020 \\
\hline $1 / 31 / 94$ & 585.60 & $8,250.40$ & $8,089.40$ & 0.981 \\
\hline $6 / 30 / 94$ & 515.90 & $7,555.30$ & $7,323.70$ & 0.969 \\
\hline $1 / 31 / 95$ & 529.00 & $8,153.00$ & $7,241.10$ & 0.888 \\
\hline
\end{tabular}

These data, specifically $\mathrm{q}_{\mathrm{v}} / \mathrm{q}_{\mathrm{l}}$, shows that after June 1993 , the production rate from the limestone interval approximately equals the volume of oil draining from the dolomite interval into the limestone interval. This type of production behavior is clearly evident in figure 6.1A. After the relatively rapid production rate decline the production rate becomes constant at about $300 \mathrm{BOPD}$. This corresponds to the time identified in table 6.1 when $q_{v}$ approximately equals $q_{l}$, and is interpreted as representing the slower gravity drainage replenishment of the limestone interval. The impact of production from the dolomite interval, $q_{d}$, is minimal since it represents a small fraction of the total production. Additional simulation runs project a 22 percent recovery factor under primary depletion (through the year 2020).

\subsection{Future Work}

Upon completion of the last set of relative permeability work for the limestone interval and calibration of the equation of state, the final field simulation study will begin. The reservoir model (see section 4., Geological Characterization of the Carbonate Reservoir in the Desert Creek Zone) will be used and three-dimensional simulation will start with a history match of past field performance. This will be followed with reservoir performance predictions to assess waterflooding and $\mathrm{CO}_{2}$ injection processes during 1996. 


\title{
7. TECHNOLOGY TRANSFER
}

\author{
Thomas C. Chidsey, Jr.
}

Utah Geological Survey

The UGS is the Principal Investigator and prime contractor for three government-industry cooperative petroleum-research projects including the Paradox basin project. These projects are designed to improve recovery, development, and exploration of the nation's oil and gas resources through use of better, more efficient technologies. The projects involve detailed geologic and engineering characterization of several complex heterogeneous reservoirs. The Class II Paradox basin and the Class I Bluebell field (Uinta Basin) projects will include practical oil-field demonstrations of selected technologies. The third project involves geological characterization and reservoir simulation of the Ferron Sandstone on the west flank of the San Rafael uplift as a surface analogue of a fluvial-dominated deltaic reservoir. The U.S. Department of Energy (DOE) and multidisciplinary teams from petroleum companies, petroleum service companies, universities, and State agencies are co-funding the three projects.

The UGS will release all products of the Paradox basin project in a series of formal publications. These will include all the data as well as the results and interpretations. Syntheses and highlights will be submitted to referred journals as appropriate, such as the American Association of Petroleum Geologists (AAPG) Bulletin and Journal of Petroleum Technology, and to trade publications such as the Oil and Gas Journal, as well as the UGS Petroleum News and Survey Notes (figure 7.1).

Project materials, plans, and objectives were displayed at the UGS booth during the 1994 and 1995 annual national conventions of the AAPG in Denver, Colorado and Houston, Texas; the 1995 AAPG Rocky Mountain Section meeting in Reno, Nevada; and at the 1995 regional convention of the Society of Petroleum Engineers in Denver, Colorado. Three to four UGS scientists staffed the display booth at these events. Abstracts were submitted for technical presentations at future AAPG national and regional meetings. Project displays will be included as part of the UGS booth at these meetings throughout the duration of the project.

The UGS has established a home page on the Internet. The address is http://utstdpwww.state.ut.us/ ugs/. The site includes (among other things) a page under the heading

Utah's Petroleum Resources, describing the UGS/DOE cooperative studies (Paradox basin, Bluebell field, and Ferron Sandstone) and Petroleum News.

\subsection{Utah Geological Survey Petroleum News and Survey Notes}

The purpose of the UGS Petroleum News newsletter is to keep petroleum companies, researchers, and other parties involved in exploring and developing Utah energy resources, informed of the progress on various energy-related UGS projects. The UGS Petroleum News contains articles on: (1) DOE-funded and other UGS petroleum project activities, progress, and results, (2) current drilling activity in Utah including coalbed methane, (3) new acquisitions of well cuttings, core, and crude oil at the UGS Sample Library, and (4) new UGS petroleum publications. The purpose of Survey Notes is to provide nontechnical information on contemporary geologic topics, issues, events, and ongoing UGS projects to Utah's geologic community, educators, state and local officials and 


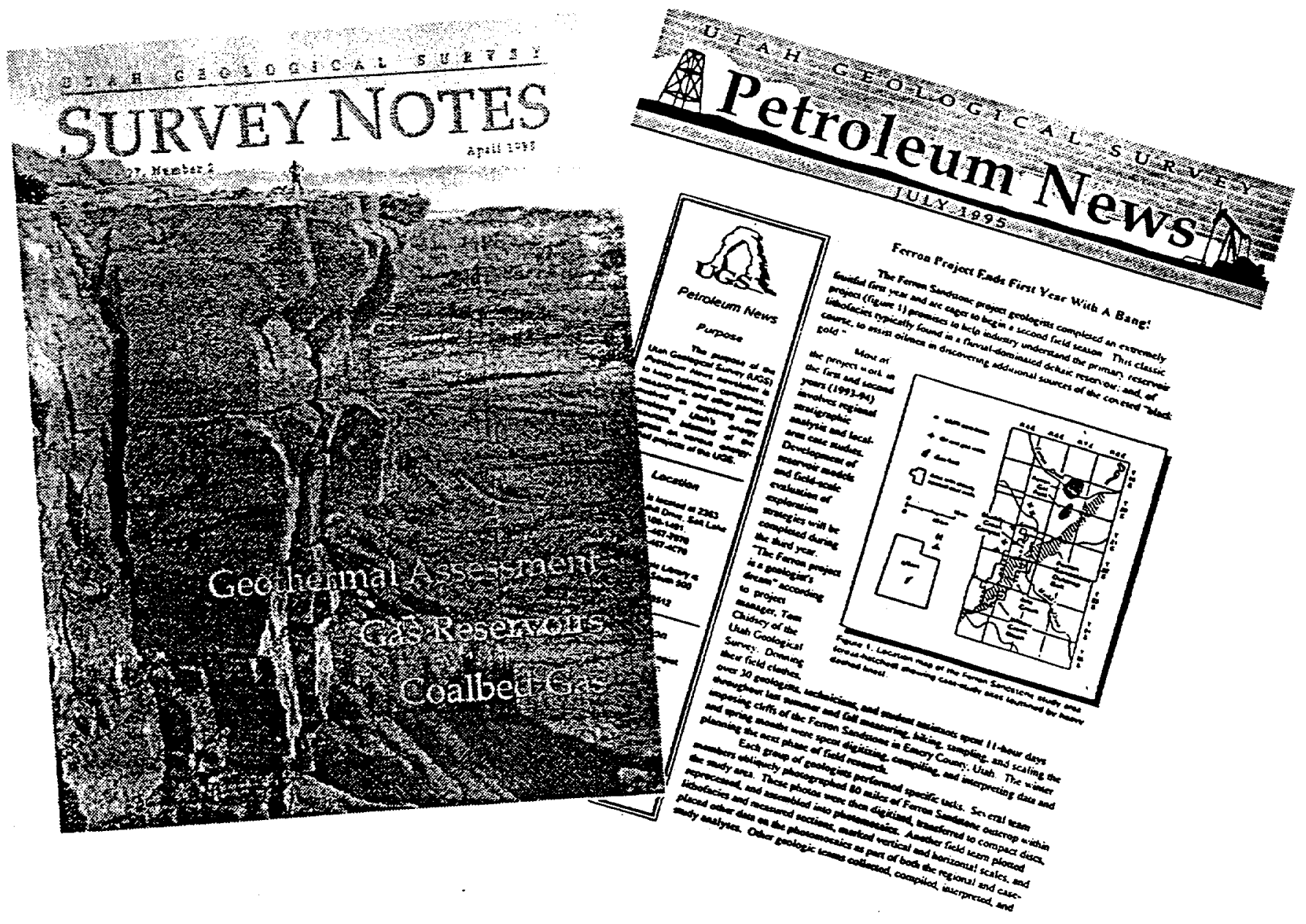

Figure 7.1. UGS Survey Notes and Petroleum News provide project updates, publication notices, and announcements of presentations to both the industry and lay public. 
other decision makers, and the public. Survey Notes is published three times yearly and Petroleum News is published semi-annually. Single copies are distributed free of charge and reproduction (with recognition of source) is encouraged. The UGS maintains a database which includes those companies or individuals specifically interested in the Paradox basin project ( 90 as of February 1996) or other DOE-sponsored projects.

\subsection{Workshops, Presentations, and the 1996 Paradox Basin Symposium}

The UGS, Harken Southwest Corporation, and the DOE sponsored a core workshop to examine several cores from the Paradox basin to determine oil reservoir characteristics of several types of algal mounds and other carbonate buildups that comprise the five project fields targeted for detailed study. The workshop was held during the AAPG Annual Convention in Denver, Colorado, June 1994. Thirty-two participants attended the free workshop. This workshop was the first of several planned in the future as part of the technology transfer activities for the project.

The core workshop was a "hands-on" introduction to the relation between production and reservoir characteristics of carbonate buildups in the Paradox Formation (figure 7.2). Representative cores from five types of oil-producing buildups were discussed and examined. Planned activities for this DOE project were described during the workshop. Participants were encouraged to ask questions and discuss all aspects of the project, and make suggestions or recommendations concerning the project. The UGS plans to publish the workshop course notes in the near future.

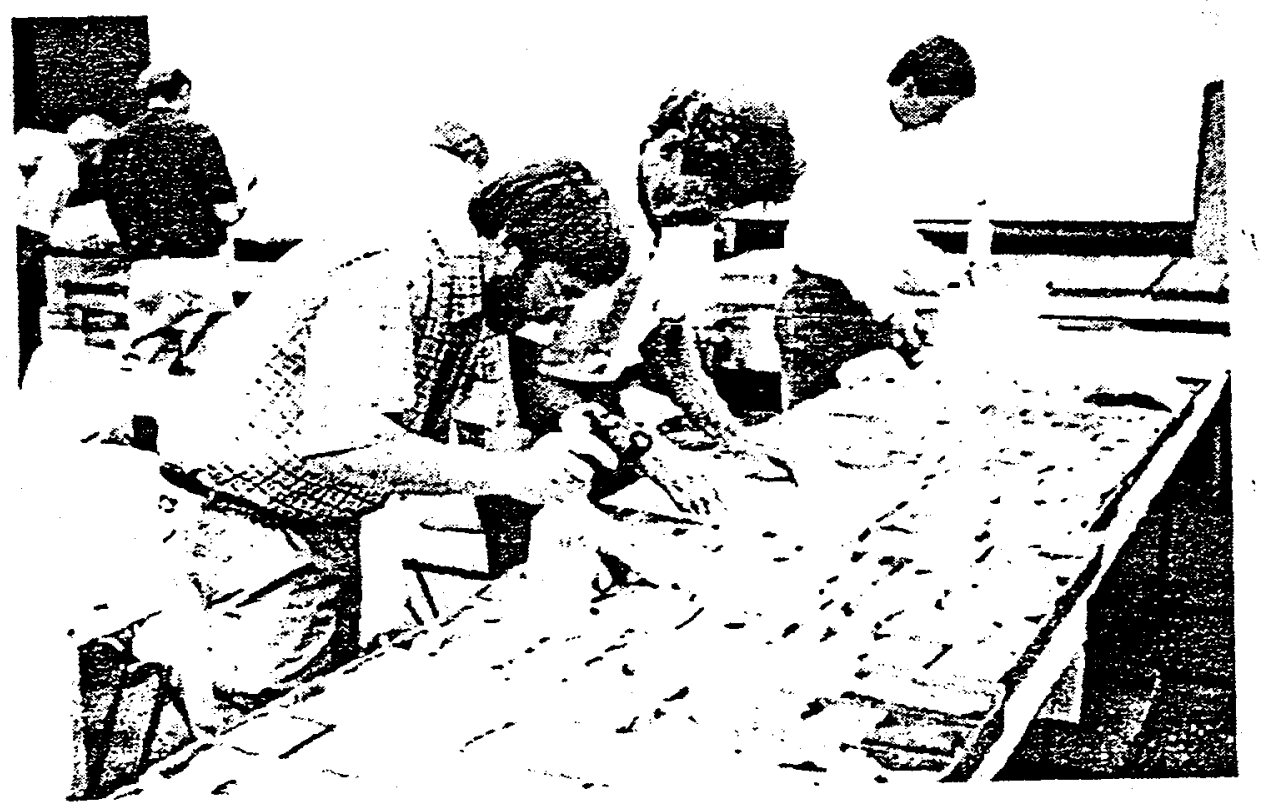

Figure 7.2. Participants at the UGS-sponsored core workshop, during the 1994 AAPG Annual Convention in Denver, Colorado, examine cores representing various types of oil-producing reservoirs from the Paradox basin project fields. 
A presentation entitled "Composition of Seismically Identified Upper Pennsylvanian Mounds Surrounding Greater Aneth Field: Implications for Increased Oil Production.Utilizing Secondary and Tertiary Recovery" was given by David E. Eby at the Fort Worth Geological Society's monthly meeting, Fort Worth, Texas, November 13, 1995. The Paradox Formation reservoir types, reservoir controls, and project objectives were discussed.

Future technology transfer includes a Geology and Resources of the Paradox Basin symposium and field trip scheduled for September 17-21, 1996 in Durango, Colorado. Sponsoring organizations are the Bureau of Indian Affairs, Utah Geological Survey, Colorado Geological Survey, U.S. Geological Survey, Utah Geological Association, Four Corners Geological Society, Fort Lewis College, and Ute Mountain Ute Indian Tribe. The two-day symposium will be preceded by a three-day field trip. The symposium will include poster and oral technical sessions, keynote addresses, and a UGS workshop presenting the results of the geological and reservoir characterization (phase I [budget period 1]) of the Class II Paradox basin project. The UGS will conduct visits to outcrop reservoir analogues along the San Juan River and tours of production facilities at Mule field during the field trip. A special guidebook will be published as part of the symposium and will include papers derived from the UGS project.

\subsection{Addressing Regulatory Issues}

The UGS Director and Energy Section Chief were invited to meet with county commissioners from every oil producing county in the State, representatives from the State Tax Commission, and Utah Association of Counties to address regulatory issues affecting future oil production and activities. State tax incentives for enhanced oil-recovery (EOR), particularly $\mathrm{CO}_{2}$ floods, and horizontal-drilling projects were discussed. The UGS explained technical aspects of such projects using the DOE-sponsored Bluebell, Monument Butte (both Class I), and Paradox basin (Class II) as examples of the economic potential of EOR and horizontal drilling.

UGS personnel also met with the Utah Department of Natural Resources Executive Director and representatives of the Utah Office of Energy and Resource Planning. That meeting helped establish the Department's position on a state legislative bill that provides tax incentives for EOR and horizontal-drilling projects.

The UGS is preparing a white paper in cooperation with the Utah Office of Energy and Resource Planning outlining a state strategic initiative to increase oil production in Utah. The strategy will focus on expanding government/industry partnerships similar to those established in the Paradox basin and Bluebell projects, and modifying tax philosophies and regulatory processes to take into account varying reservoir conditions. 


\section{APPENDIX A}

\section{PARADOX BASIN PROJECT FIELD SUMMARIES NAVAJO NATION SAN JUAN COUNTY, UTAH}




\title{
RUNWAY
}

\author{
T. 40 S., R. 25 E., of the Salt Lake Base Line \\ San Juan County, Utah
}

\section{General Field Data}

Regional Setting: Southwestern shelf, Paradox basin

Producing Formation(s): Pennsylvanian, Desmoinesian-Desert Creek and Ismay zones of the Paradox Formation

Type of Trap: Stratigraphic, carbonate buildup (bryozoan-dominated mound and phylloid algal intervals)

Exploration Method Leading to Discovery: Geophysical seismic surveys, subsurface geology

Other Significant Shows: Lower Ismay zone of the Paradox Formation

Oldest Stratigraphic Horizon Penetrated: Pennsylvanian - Hermosa Group

Surface Formation(s): Jurassic - Morrison Formation

Spacing: state-wide, 40 acres

Productive Area: 193 acres

Completion Practice: Selective perforation and acidize (treatment size varies)

Logging Practice: Dual laterolog-microsperically focused log (DLL-MSFL) with gamma ray (GR), microlog, compensated neutron log-formation compensated density log (CNLFDC) litho-density with GR, borehole-compensated (BHC-) sonic with GR; rotary sidewall core (SWC), mudlog

Number of Producing Wells: 3

Number of Abandoned Producers: 0

Number of Dry Holes: 0

Number of Shut-in Wells: 0

Number of Disposal Wells: 0

Number of Secondary Recovery Injection Wells: 0

Market for Production: Oil to Gary-Williams Energy Corporation, Denver, Colorado and Giant Refining Company, Scottsdale, Arizona; gas to El Paso Natural Gas Company, El Paso, Texas

Method of Transportation: Oil is trucked to Tex-New Mexico pipeline at Montezuma Creek, Utah; gas transported via pipeline to Aneth Gas Plant which connects to Western Gas Resources pipeline at Montezuma Creek

Major Operators: Harken Southwest Corporation

\section{Discovery Well}

Name: Runway No. 10-G-1

Location: SW1/4NE1/4 section 10, T. 40 S., R. 25 E., of the Salt Lake Base Line Date of Completion: June 24, 1990

Initial Potential: Desert Creek and Upper Ismay zones commingled - initial potential flow (IPF) 825 BOPD and 895 MCFGPD on a 24/64-inch choke (ck), flowing tubing pressure (FTP) $640 \mathrm{psi}$

Initial Pressure: 2,162 psig (Desert Creek) 
Perforations: Upper Ismay - 5,896-5,906 feet (w/ 2 shots/foot [shots/ft]); Desert Creek - 6,04268 feet ( $w / 2$ shots/ft), 6,086-6,104 feet (w/ 4 shots/ft)

Treatment: 5,896-5,906 feet acidized w/ 2,000 gallons (gals) 28 percent MSR-100, 250 gals 28 percent MSR-100+, and 4,000 gals 28 percent gelled acid; 6,042-68 feet acidized w/ 3,600 gals 28 percent MSR-100, 6,086-6,104 feet acidized w/ 5,200 gals 28 percent MSR-100

Casing:85/8 inch @ 516 feet, 5 1/2 inch @ 6,201 feet

Total Depth: 6,213 feet, Paradox Formation, Akah salt zone

Elevation: 5,219 feet - graded elevation (GR); 5,233 feet - kelly bushing (KB)

\section{Reservoir Data}

Producing Formation: Paradox Formation, Desert Creek zone

Lithology: Bryozoan-dominated mound - bindstone and framestone rarely dolomitized; phylloid algal mound - porous algal bafflestone, some grainstone and dolomitized zones. Both carbonate buildups are interbedded with low permeable wackestone and mudstone.

Type of Drive: Gas expansion

Net Pay Thickness: 50 feet

Geometry of Reservoir Rock: Lenticular, west to east-northeast trending lobate mound, 0.9 miles long and 0.5 miles wide

Porosity: $6.0-20.3$ percent, average 11.9 percent (from geophysical logs and cores)

Permeability: $0.1-63.8 \mathrm{md}$, average $17.3 \mathrm{md}$ (from core analysis)

Water Saturation: $10-63.4$ percent, average 15 percent (from geophysical logs and cores)

Rw and/or Salinity: Resistivity $=0.07 \mathrm{ohm}-\mathrm{m} @ 67^{\circ} \mathrm{F} ; \mathrm{pH}=6.0$; total dissolved solids = 199,709 ppm, 42,900 ppm Na, 31,700 ppm Ca, 729 ppm Mg, 124,000 ppm Cl, 366 ppm $\mathrm{HCO}_{3}, 14 \mathrm{ppm} \mathrm{SO}_{4}$ (from produced water from tank battery [commingled Desert Creek and Ismay])

Bottom-Hole Temperature (BHT): $126^{\circ} \mathrm{F} @ 6,203$ feet (from geophysical logs)

Initial Gas-Oil Ratio: 967 scf/STB

Initial Field Pressure: 2,162 psig

Present Field Pressure: $200-300$ psi

Oil and/or Gas Characteristics: Oil: $40.5^{\circ}$ API gravity, viscosity 0.314 centipoise (cP) @ initial reservoir conditions, sulfur 0.0 percent by weight, dark green color; gas: British thermal units/foot ${ }^{3}\left(\mathrm{BTU} / \mathrm{ft}^{3}\right)-1,356.5$, specific gravity -0.779 , carbon dioxide -0.6 percent, nitrogen - 1.1 percent, oxygen - 0.0 percent, methane - 71.5 percent, ethane - 15.4 percent, propane -7.3 percent, $i$-butane -0.7 percent, $n$-butane - 0.4 percent, $i$-pentane 0.4 percent, n-pentane - 0.4 percent, hexanes -0.6 percent, heptanes+ -0.0 percent, hydrogen sulfide - N/A.

Gas, Oil, and Water Contact: Unknown

Estimated Primary Recovery: 720,000 BO, 2.83 BCFG

Type of Secondary Recovery: None present, may initiate waterflood or $\mathrm{CO}_{2}$ flood

Estimated Secondary Recovery: Unknown

Estimated Ultimate Recovery: Unknown 


\section{Reservoir Data}

Producing Formation: Paradox Formation, Ismay zone

Lithology: Limestone and sucrosic dolomite

Type of Drive: Gas expansion

Net Pay Thickness: 22 feet

Geometry of Reservoir Rock: Lenticular, southwest to northeast trending lobate mound, 0.9 miles long and 0.4 miles wide

Porosity: $9.0-14.9$ percent, average 11.7 percent (from geophysical logs and cores)

Permeability: $1.4-6.4 \mathrm{md}$, average $2.7 \mathrm{md}$ (from core analysis)

Water Saturation: $16-33$ percent, average 23.6 percent (from geophysical logs and cores)

Rw and/or Salinity: Resistivity $=0.07 \mathrm{ohm}-\mathrm{m} @ 67^{\circ} \mathrm{F} ; \mathrm{pH}=6.0$; total dissolved solids = 199,709 ppm, 42,900 ppm Na, 31,700 ppm Ca, 729 ppm Mg, 124,000 ppm Cl, 366 ppm $\mathrm{HCO}_{3}, 14 \mathrm{ppm} \mathrm{SO}$ (from produced water from tank battery [commingled Desert Creek and Ismay])

Bottom-Hole Temperature: $126^{\circ} \mathrm{F} @ 6,203$ feet (from geophysical logs)

Gas-Oil Ratio: 1,085:1

Initial Field Pressure: 2,162 psig

Present Field Pressure: $200-300$ psi

Oil and/or Gas Characteristics: Oil: $43.2^{\circ}$ API gravity, sulfur 0.0 percent by weight, color dark green; gas: $\mathrm{BTU} / \mathrm{ft}^{3}-1,804.5$, specific gravity - 1.319 , carbon dioxide -0.1 percent, nitrogen - 17.8 percent, oxygen - 0.0 percent, methane - 14.5 percent, ethane -20.7 percent, propane - 31.3 percent, i-butane -3.2 percent, n-butane - 5.0 percent, i-pentane 1.9 percent, $\mathrm{n}$-pentane -2.1 percent, hexanes -3.5 percent, hydrogen sulfide -0.0 percent.

Gas, Oil, and Water Contact: Unknown

Estimated Primary Recovery: 80,000 BO, 0.16 BCFG

Type of Secondary Recovery: None present, may initiate waterflood or $\mathrm{CO}_{2}$ flood

Estimated Secondary Recovery: Unknown

Estimated Ultimate Recovery: Unknown

Cumulative Production (Desert Creek and Ismay zones commingled): 750,772 BO, 2,268,636 thousand cubic feet of gas (MCFG), and 3,036 bbls of water (BW) as of January 1, 1996 (Utah Division of Oil, Gas and Mining, 1996) 


\section{HERON NORTH}

\section{T. 41 S., R. 25 E., of the Salt Lake Base Line}

San Juan County, Utah

\section{General Field Data}

Regional Setting: Southwestern shelf, Paradox basin

Producing Formation(s): Pennsylvanian, Desmoinesian-Desert Creek zone of the Paradox Formation

Type of Trap: Stratigraphic, carbonate buildup (bioclastic calcarenite mound)

Exploration Method Leading to Discovery: Geophysical seismic surveys, subsurface geology

Other Significant Shows: Ismay zone of the Paradox Formation

Oldest Stratigraphic Horizon Penetrated: Pennsylvanian - Hermosa Group

Surface Formation(s): Jurassic - Morrison Formation

Spacing: state-wide, 40 acres

Productive Area: 110 acres

Completion Practice: Selective perforation and acidize (treatment size varies)

Logging Practice: DLL-MSFL with GR, CNL-FDC litho-density with GR, BHC-sonic with GR, mudlog

Number of Producing Wells: 1

Number of Abandoned Producers: 0

Number of Dry Holes: 0

Number of Shut-in Wells: 0

Number of Disposal Wells: 0

Number of Secondary Recovery Injection Wells: 0

Market for Production: Oil to Gary-Williams Energy Corporation, Denver, Colorado and Giant Refining Company, Scottsdale, Arizona; gas to El Paso Natural Gas Company, El Paso, Texas

Method of Transportation: Oil is trucked to Tex-New Mexico pipeline at Montezuma Creek, Utah; gas transported via pipeline to Aneth Gas Plant which connects to Western Gas

Resources pipeline at Montezuma Creek

Major Operators: Harken Southwest Corporation

\section{Discovery Well}

Name: North Heron No. 35-C

Location: NE1/4NW1/4 section 35, T. 41 S., R. 25 E., of the Salt Lake Base Line

Date of Completion: October 26, 1991

Initial Potential: Desert Creek zone - IPF 605 BOPD and 230 MCFGPD on a 24/64-inch ck, FTP 260 psig

Initial Pressure: $1,934 \mathrm{psig}$

Perforations: $5,584-5,606$ feet ( $w / 4$ shots/ft)

Treatment: 5,584-5,606 feet acidized $w / 4,400$ gals 28 percent MSR-100

Casing: $85 / 8$ inch @ 522 feet, $51 / 2$ inch @ 5,752 feet

Total Depth: 5,752 feet, Paradox Formation, Akah salt zone 
Elevation: 4,747 feet - GR; 4,760 feet $-\mathrm{KB}$

\section{Reservoir Data}

Producing Formation: Paradox Formation, Desert Creek zone

Lithology: Porous, dolomitized calcarenite (packstone to grainstone to rudstone) above tight, anhydrite- and salt-plugged algal bafflestone. The calcarenite and bafflestone intervals are separated by low permeable, dolomitized wackestone and mudstone

Type of Drive: Gas expansion

Net Pay Thickness: 60 feet

Geometry of Reservoir Rock: Lenticular, northwest to southeast trending linear mound/beach complex, 0.75 miles long and 0.5 miles wide

Porosity: $7.8-20.9$ percent, average 15 percent (from geophysical logs and cores)

Permeability: $1.2-70.1 \mathrm{md}$, average $17.7 \mathrm{md}$ (from core analysis)

Water Saturation: $19.3-66.6$ percent, average 15 percent (from core analysis)

Rw and/or Salinity: 0.035 ohm-m @ BHT

Bottom-Hole Temperature: $126^{\circ} \mathrm{F} @ 5,752$ feet (from geophysical logs)

Initial Gas-Oil Ratio: $644 \mathrm{scf} / \mathrm{STB}$

Initial Field Pressure: 1,934 psig

Present Field Pressure: $200-300$ psi

Oil and/or Gas Characteristics: Oil: $44.0^{\circ}$ API gravity, viscosity $0.475 \mathrm{cP} @$ initial reservoir conditions, sulfur 0.0 percent by weight, color dark green; gas: BTU/ $/ \mathrm{ft}^{3}-1,321$, specific gravity -0.8335 , carbon dioxide -4.3 percent, nitrogen - 1.1 percent, oxygen - N/A, methane -64.6 percent, hydrogen sulfide - N/A.

Gas, Oil, and Water Contact: Unknown

Cumulative Production: 200,759 BO, 305,669 MCFG, and 23,578 BW as of January 1, 1996

(Utah Division of Oil, Gas and Mining, 1996)

Estimated Primary Recovery: 990,000 BO, 2.65 BCFG

Type of Secondary Recovery: None present, may initiate waterflood or $\mathrm{CO}_{2}$ flood i

Estimated Secondary Recovery: Unknown

Estimated Ultimate Recovery: Unknown 


\section{MULE \\ T. 41 S., R. 24 E., of the Salt Lake Base Line \\ San Juan County, Utah}

\section{General Field Data}

Regional Setting: Southwestern shelf, Paradox basin

Producing Formation(s): Pennsylvanian, Desmoinesian-Desert Creek zone of the Paradox Formation

Type of Trap: Stratigraphic, carbonate buildup (phylloid algal mound)

Exploration Method Leading to Discovery: Geophysical seismic surveys, subsurface geology

Other Significant Shows: Ismay zone of the Paradox Formation

Oldest Stratigraphic Horizon Penetrated: Pennsylvanian - Hermosa Group

Surface Formation(s): Jurassic - Morrison Formation

Spacing: 80 acres

Productive Area: 48 acres

Completion Practice: Selective perforation and acidize (treatment size varies)

Logging Practice: DLL with GR, CNL-FDC litho-density with GR, BHC-sonic-GR, formation microscanner (FMS), microlog, mudlog

Number of Producing Wells: 1

Number of Abandoned Producers: 0

Number of Dry Holes: 0

Number of Shut-in Wells: 1

Number of Disposal Wells: 0

Number of Secondary Recovery Injection Wells: 0

Market for Production: Oil to Gary-Williams Energy Corporation, Denver, Colorado and Giant Refining Company, Scottsdale, Arizona; gas to El Paso Natural Gas Company, El Paso, Texas

Method of Transportation: Oil is trucked to Tex-New Mexico pipeline at Montezuma Creek, Utah; gas transported via pipeline to Aneth Gas Plant which connects to Western Gas Resources pipeline at Montezuma Creek

Major Operators: Harken Southwest Corporation

\section{Discovery Well}

Name: Mule No. 31-K-1 (N)

Location: SW1/4SW1/4 section 31, T. 41 S., R. 24 E., of the Salt Lake Base Line

Date of Completion: October 13, 1991

Initial Potential: Desert Creek zone - approximately 10 bbls of oil per hour (based on several swab tests) w/ water cut increasing on each test

Initial Pressure: rapid draw down

Perforations: 6,003-08 feet, 6,010-29 feet (w/ 4 shots/ft)

Treatment: $6,003-08$ feet acidized w/ 4,800 gals 28 percent gelled MSR-100; 6,010-29 feet acidized $w / 8,000$ gals 28 percent gelled MSR-100

Casing:85/8 inch @520 feet, 5 1/2 inch@6,162 feet 
Total Depth: 6,162 feet, Paradox Formation, Akah salt zone

Elevation: 4,940 feet - GR; 4,952 feet - KB

\section{Reservoir Data}

Producing Formation: Paradox Formation, Desert Creek zone

Lithology: Porous algal bafflestone and crinoidal packstone with dolomitized zones interbedded with low permeable wackestone, mudstone, and dolomite

Type of Drive: Gas expansion

Net Pay Thickness: 47 feet

Geometry of Reservoir Rock: Lenticular, northeast to east trending linear mound/mound flank deposit, 0.5 miles long and 900 feet wide

Porosity: 7.5-24.2 percent, average 13 percent (from geophysical logs and core analysis)

Permeability: $0.1-234 \mathrm{md}$; average for mound core interval (30 percent of the reservoir) approximately $\approx 190 \mathrm{md}$, average for the supra-mound interval ( 70 percent of the reservoir) $\approx 2 \mathrm{md}$ (from core analysis)

Water Saturation: $12-50.4$ percent, average 15 percent (from core analysis)

Rw and/or Salinity: 0.035 ohm-m @ BHT

Bottom-Hole Temperature: $128^{\circ} \mathrm{F} @ 5,804$ feet (from geophysical logs)

Initial Gas-Oil Ratio: $478 \mathrm{scf} / \mathrm{STB}$

Initial Field Pressure: $2,050 \mathrm{psi}$

Present Field Pressure: $200-300$ psi

Oil and/or Gas Characteristics: $44.0^{\circ}$ API gravity, sulfur 0.0 percent by weight, color dark green; gas: BTU/ $\mathrm{ft}^{3}-1,539$, specific gravity -0.8890 , carbon dioxide -0.04 percent, nitrogen - 1.5 percent, oxygen -0.0 percent, methane -61.8 percent, hydrogen sulfide 0.0 percent.

Gas, Oil, and Water Contact: Unknown

Cumulative Production: 343,180 BO, 203,116 MCFG, and 17,930 BW as of January 1, 1996

(Utah Division of Oil, Gas and Mining, 1996)

Estimated Primary Recovery: 430,603 BO, 0.288 BCFG

Type of Secondary Recovery: None present, may initiate waterflood or $\mathrm{CO}_{2}$ flood

Estimated Secondary Recovery: Unknown

Estimated Ultimate Recovery: Unknown 


\section{BLUE HOGAN \\ T. 42 S., R. 23 E., of the Salt Lake Base Line \\ San Juan County, Utah}

\section{General Field Data}

Regional Setting: Southwestern shelf, Paradox basin

Producing Formation(s): Pennsylvanian, Desmoinesian-Desert Creek zone of the Paradox Formation

Type of Trap: Stratigraphic, carbonate buildup (phylloid algal mound)

Exploration Method Leading to Discovery: Geophysical seismic surveys, subsurface geology

Other Significant Shows: None

Oldest Stratigraphic Horizon Penetrated: Pennsylvanian - Hermosa Group

Surface Formation(s): Jurassic - Morrison Formation

Spacing: 80 acres

Productive Area: 89 acres

Completion Practice: Selective perforation and acidize (treatment size varies)

Logging Practice: DLL-MSFL with GR, microlog, CNL-FDC litho-density with GR, BHCsonic with GR, mudlog

Number of Producing Wells: 1

Number of Abandoned Producers: 0

Number of Dry Holes: 0

Number of Shut-in Wells: 0

Number of Disposal Wells: 0

Number of Secondary Recovery Injection Wells: 0

Market for Production: Oil to Gary-Williams Energy Corporation, Denver, Colorado and Giant Refining Company, Scottsdale, Arizona; gas to El Paso Natural Gas Company, El Paso, Texas

Method of Transportation: Oil is trucked to Tex-New Mexico pipeline at Montezuma Creek, Utah; gas transported via pipeline to Aneth Gas Plant which connects to Western Gas

Resources pipeline at Montezuma Creek

Major Operators: Harken Southwest Corporation

\section{Discovery Well}

Name: Blue Hogan No. 1-J-1

Location: NE1/4NW1/4SE1/4 section 1, T. 42 S., R. 23 E., of the Salt Lake Base Line Date of Completion: February 6, 1991

Initial Potential: Desert Creek zone - IPF 1,167 BOPD, 722 MCFGPD, and 5 bbls of water per day (BWPD) on a 30/64-inch ck, FTP 265 psi

Initial Pressure: $1,800 \mathrm{psi}$

Perforations: 5,400-46 feet, 5,454-77 feet, 5,488-5,522 feet, 5,530-42 feet, 5,554-62 feet(w/ 4 shots/ft)

Treatment: $5,400-46$ feet acidized w/ 13,800 gals 28 percent MSR-100; 5,454-77 feet acidized w/ 6,900 gals 28 percent MSR-100; 5,488-5,522 feet acidized w/ 10,200 gals 28 percent 
MSR-100; 5,530-42 feet acidized w/ 3,600 gals 28 percent MSR-100; 5,554-62 feet acidized $\mathrm{w} / 2,400$ gals 28 percent MSR-100

Casing: $85 / 8$ inch @ 492 feet, $51 / 2$ inch @ 5,611 feet

Total Depth: 5,613 feet, Paradox Formation, Akah salt zone

Elevation: 4,995 feet - GR; 5,009 feet - KB

\section{Reservoir Data}

Producing Formation: Paradox Formation, Desert Creek zone

Lithology: Porous algal bafflestone and dolomitized zones interbedded with low permeable wackestone and mudstone

Type of Drive: Gas expansion

Net Pay Thickness: 82 feet

Geometry of Reservoir Rock: Lenticular, northwest to southeast trending linear mound, 0.5 miles long and 1,000 feet wide

Porosity: 6-16.5 percent, average 9.1 percent (from geophysical logs and cores)

Permeability: $0.1-425 \mathrm{md}$; average for mound core interval ( 30 percent of the reservoir) approximately $\approx 190 \mathrm{md}$, average for the supra-mound interval ( 70 percent of the reservoir) $\approx 2 \mathrm{md}$ (from core analysis)

Water Saturation: $17-56$ percent, average 15 percent (from geophysical logs and cores)

Rw and/or Salinity: 0.035 ohm-m @ BHT

Bottom-Hole Temperature: $128^{\circ} \mathrm{F} @ 5,613$ feet (from geophysical logs)

Initial Gas-Oil Ratio: $487 \mathrm{scf} / \mathrm{STB}$

Initial Field Pressure: $1,800 \mathrm{psi}$

Present Field Pressure: $200-300$ psi

Oil and/or Gas Characteristics: $40.6^{\circ} \mathrm{API}$ gravity, viscosity $0.811 \mathrm{cP} @$ initial reservoir conditions, sulfur 0.0 percent by weight, color dark green; gas: BTU/ $/ \mathrm{ft}^{3}-1,497$, specific gravity - 0.8992 , carbon dioxide - 0.1 percent, nitrogen -2.4 percent, oxygen -0.0 percent, methane -60.6 percent, hydrogen sulfide -0.0 percent.

Gas, Oil, and Water Contact: Unknown

Cumulative Production: 282,718 BO, 256,006 MCFG, and 1,699 BW as of January 1, 1996 (Utah Division of Oil, Gas and Mining, 1996)

Estimated Primary Recovery: 645,000 BO, 0.968 BCFG

Type of Secondary Recovery: None present, may initiate waterflood or $\mathrm{CO}_{2}$ flood

Estimated Secondary Recovery: Unknown

Estimated Ultimate Recovery: Unknown 


\author{
ANASAZI \\ T. 42 S., R. 24 E., of the Salt Lake Base Line \\ San Juan County, Utah \\ General Field Data
}

Regional Setting: Southwestern shelf, Paradox basin

Producing Formation(s): Pennsylvanian, Desmoinesian-Desert Creek zone of the Paradox

Formation

Type of Trap: Stratigraphic, carbonate buildup (phylloid algal mound)

Exploration Method Leading to Discovery: Geophysical seismic surveys, subsurface geology

Other Significant Shows: Ismay zone of the Paradox Formation

Oldest Stratigraphic Horizon Penetrated: Pennsylvanian - Hermosa Group

Surface Formation(s): Jurassic - Morrison Formation

Spacing: 80 acres

Productive Area: 165 acres

Completion Practice: Selective perforation and acidize (treatment size varies)

Logging Practice: DLL-MSFL with GR and spontaneous potential (SP), microlog, CNL-FDC litho-density with GR, BHC-sonic with GR, rotary SWC, mudlog

Number of Producing Wells: 4

Number of Abandoned Producers: 0

Number of Dry Holes: 0

Number of Shut-in Wells: 0

Number of Disposal Wells: 0

Number of Secondary Recovery Injection Wells: 0

Market for Production: Oil to Gary-Williams Energy Corporation, Denver, Colorado and

Giant Refining Company, Scottsdale, Arizona; gas to El Paso Natural Gas Company, El

Paso, Texas

Method of Transportation: Oil is trucked to Tex-New Mexico pipeline at Montezuma Creek,

Utah; gas transported via pipeline to Aneth Gas Plant which connects to Western Gas

Resources pipeline at Montezuma Creek

Major Operators: Harken Southwest Corporation

\title{
Discovery Well
}

Name: Anasazi No. 1

Location: SE1/4SW1/4NW1/4 section 5, T. 42 S., R. 24 E., of the Salt Lake Base Line

Date of Completion: January 23, 1990

Initial Potential: Desert Creek zone - IPF 1,705 BOPD and 833 MCFGPD on a 48/64-inch ck, FTP $170 \mathrm{psi}$

Initial Pressure: $1,945 \mathrm{psi}$

Perforations: $5,574-5,630$ feet, $5,646-70$ feet ( $w / 2$ shots/ft)

Treatment: 5,574-5,630 feet acidized w/ 22,400 gals 28 percent MSR-100, 5,646-70 feet acidized w/ 4,800 gals 28 percent MSR-100

Casing: $85 / 8$ inch @ 504 feet, 5 1/2 inch @ 5,780 feet 
Total Depth: 5,780 feet, Paradox Formation, Akah salt zone

Elevation: 4,778 feet - GR; 4,790 feet $-\mathrm{KB}$

\section{Reservoir Data}

Producing Formation: Paradox Formation, Desert Creek zone

Lithology: Porous algal bafflestone, some grainstone and dolomitized zones interbedded with low permeable wackestone and mudstone

Type of Drive: Gas expansion

Net Pay Thickness: 46 feet (average from four wells)

Geometry of Reservoir Rock: Lenticular, west to northeast trending lobate mound, 0.9 miles long and 2,000- to 3,000-feet wide

Porosity: 6.8-24.5 percent, average 14.1 percent (from geophysical logs and cores)

Permeability: $0.1-2,180 \mathrm{md}$; average for mound core interval (30 percent of the reservoir) approximately $\approx 190 \mathrm{md}$, average for the supra-mound interval ( 70 percent of the reservoir) $\approx 2 \mathrm{md}$ (from core analysis)

Water Saturation: $10-57$ percent, average 15 percent (from geophysical logs and cores)

Rw and/or Salinity: $0.035 \mathrm{ohm}-\mathrm{m} @$ bottom-hole temperature (BHT)

Bottom-Hole Temperature: $138^{\circ} \mathrm{F} @ 5,777$ feet (from geophysical logs)

Initial Gas-Oil Ratio: 364 scf/STB

Initial Field Pressure: 1,945 psi

Present Field Pressure: $200-300$ psi

Oil and/or Gas Characteristics: Oil: 41 ${ }^{\circ}$ API gravity, viscosity $0.951 \mathrm{cP} @$ initial reservoir conditions, sulfur 0.0 percent by weight, color dark green; Gas: BTU/ $\mathrm{ft}^{3}-1,400.3$, specific gravity -0.8080 , carbon dioxide -2.3 percent, nitrogen -0.4 percent, oxygen 0.0 percent, methane -20.2 percent, hydrogen sulfide -0.0 percent.

Gas, Oil, and Water Contact: None

Cumulative Production: 1,650,133 BO, 1,281,713 MCFG, and 25,274 BW as of January 1, 1996 (Utah Division of Oil, Gas and Mining, 1996)

Estimated Primary Recovery: 2,069,392 BO, 1.89 BCFG

Type of Secondary Recovery: None present, may initiate waterflood or $\mathrm{CO}_{2}$ flood

Estimated Secondary Recovery: Unknown

Estimated Ultimate Recovery: Unknown 


\section{REFERENCES}

Utah Division of Oil, Gas and Mining, 1996, Oil and gas production report, December 1995: non-paginated. 


\section{APPENDIX B}

COMPOSITIONAL ANALYSES OF OIL AND GAS

ANASAZI FIELD

NAVAJO NATION

SAN JUAN COUNTY, UTAH 
Table B.1. Composition of Anasazi No. 5-L separator oil cylinder No. W8301 at $73^{\circ} \mathrm{F}\left(23^{\circ} \mathrm{C}\right)$ and 1,014 psia (6,992 kpa).

\begin{tabular}{|c|c|c|c|c|c|c|}
\hline Component & $\begin{array}{l}\text { Molecular } \\
\text { Weight } \\
(\mathrm{g} / \mathrm{mole})\end{array}$ & 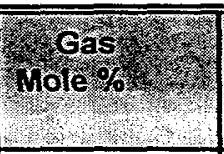 & W & Overail & Mole \% & $\begin{array}{l}\text { Sroup wole } \\
\%\end{array}$ \\
\hline $\mathrm{CO}_{2}$ & 44.010 & 0.000 & 0.000 & 0.000 & 0.000 & 0.000 \\
\hline $\mathrm{H}_{2} \mathrm{~S}$ & 34.080 & 0.000 & 0.000 & 0.000 & 0.000 & 0.000 \\
\hline $\mathrm{N}_{2}$ & 28.013 & 0.000 & 0.000 & 0.000 & 0.000 & 0.000 \\
\hline C1 & 16.043 & 12.818 & 0.000 & 0.061 & 0.673 & 0.673 \\
\hline $\mathrm{C} 2$ & 30.070 & 24.311 & 0.050 & 0.266 & 1.568 & 1.568 \\
\hline $\mathrm{C} 3$ & 44.097 & 30.424 & 0.382 & 0.775 & 3.112 & 3.112 \\
\hline I-C4 & 58.124 & 5.552 & 0.236 & 0.329 & 1.001 & 1.001 \\
\hline $\mathrm{N}-\mathrm{C} 4$ & 58.124 & 14.474 & 0.966 & 1.203 & 3.665 & 3.665 \\
\hline $1-C 5$ & 72.151 & 3.652 & 0.791 & 0.859 & 2.108 & 2.108 \\
\hline $\mathrm{N}-\mathrm{C5}$ & 72.151 & 4.214 & 1.253 & 1.327 & 3.257 & 3.257 \\
\hline C6 & 86.200 & 2.301 & 2.760 & 2.782 & 5.718 & \multirow{4}{*}{9.272} \\
\hline MCYCL-C5 & 84.160 & 0.431 & 0.767 & 0.768 & 1.616 & \\
\hline Benzene & 78.110 & 0.109 & 0.177 & 0.177 & 0.402 & \\
\hline CYCL-C6 & 84.160 & 0.282 & 0.715 & 0.712 & 1.536 & \\
\hline $\mathrm{C7}$ & 100.200 & 0.692 & 3.268 & 3.246 & 5.738 & \multirow{8}{*}{23.077} \\
\hline MCYCL-C6 & 98.190 & 0.231 & 1.460 & 1.447 & 2.611 & \\
\hline Toluene & 92.140 & 0.062 & 0.453 & 0.449 & 0.863 & \\
\hline $\mathrm{C} 8$ & 114.230 & 0.275 & 4.270 & 4.223 & 6.549 & \\
\hline C2-Benzene & 106.170 & 0.012 & 0.176 & 0.174 & 0.290 & \\
\hline M\&P-XYLENE & 106.170 & 0.019 & 0.497 & 0.491 & 0.819 & \\
\hline O-XYLENE & 106.170 & 0.007 & 0.343 & 0.339 & 0.565 & \\
\hline $\mathrm{Cg}$ & 128.300 & 0.083 & 4.137 & 4.086 & 5.641 & \\
\hline $\mathrm{C} 10$ & 134.000 & 0.033 & 4.996 & 4.932 & 6.519 & \multirow{5}{*}{23.772} \\
\hline$C_{11}$ & 147.000 & 0.009 & 4.406 & 4.348 & 5.240 & \\
\hline $\mathrm{C} 12$ & 161.000 & 0.003 & 3.751 & 3.702 & 4.073 & \\
\hline $\mathrm{C} 13$ & 175.000 & 0.002 & 4.336 & 4.279 & 4.331 & \\
\hline$C_{14}$ & 190.000 & 0.001 & 3.868 & 3.817 & 3.559 & \\
\hline
\end{tabular}


Table B.1. (continued)

\begin{tabular}{|c|c|c|c|c|c|c|}
\hline oomporent & $\begin{array}{l}\text { Molecular } \\
\text { meright } \\
\text { (gmog) }\end{array}$ & 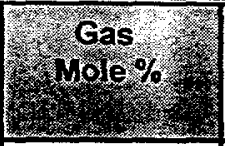 & 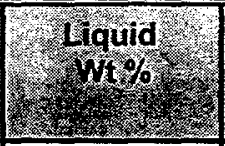 & 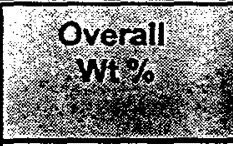 & 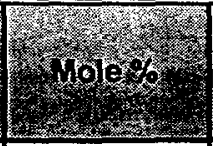 & 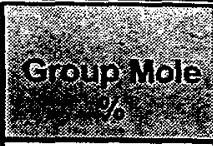 \\
\hline C15 & 206.000 & 0.001 & 3.615 & 3.567 & 3.068 & \multirow{5}{*}{$\begin{array}{c}11.783 \\
\vdots\end{array}$} \\
\hline C16 & 222.000 & 0.001 & 3.052 & 3.012 & 2.403 & \\
\hline $\mathrm{C} 17$ & 237.000 & 0.000 & 3.039 & 2.999 & 2.242 & \\
\hline C18 & 251.000 & 0.000 & 3.086 & 3.045 & 2.149 & \\
\hline$C 19$ & 263.000 & 0.000 & 2.891 & 2.853 & 1.922 & \\
\hline $\mathrm{C} 2 \mathrm{O}$ & 275.000 & 0.000 & 2.643 & 2.608 & 1.680 & \multirow{4}{*}{ 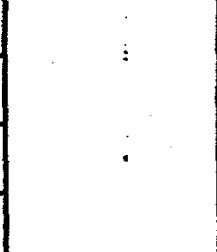 } \\
\hline $\mathrm{C} 21$ & 291.000 & 0.000 & 2.346 & 2.315 & 1.409 & \\
\hline$C 22$ & 305.000 & 0.000 & 2.295 & 2.265 & 1.315 & \\
\hline $\mathrm{C} 23$ & 318.000 & 0.000 & 2.134 & 2.106 & 1.173 & \\
\hline $\mathrm{C} 24$ & 331.000 & 0.000 & 1.947 & 1.921 & 1.028 & \multirow[t]{2}{*}{10.622} \\
\hline $\mathrm{C} 25$ & 345.000 & 0.000 & 1.888 & 1.863 & 0.957 & \\
\hline C26 & 359.000 & 0.000 & 1.755 & 1.732 & 0.855 & \multirow{4}{*}{ v } \\
\hline $\mathrm{C} 27$ & 374.000 & 0.000 & 1.725 & 1.702 & 0.806 & \\
\hline $\mathrm{C} 28$ & 388.000 & 0.000 & 1.639 & 1.617 & 0.738 & \\
\hline $\mathrm{C}_{29}$ & 402.000 & 0.000 & 1.519 & 1.499 & 0.661 & \\
\hline $\mathrm{C} 30+$ & 580.000 & 0.000 & 20.371 & 20.104 & 6.140 & 6.140 \\
\hline $\begin{array}{l}\text { The sample had } \\
\text { of the (1) gas pha } \\
177.137 \mathrm{~g} / \text { mole. }\end{array}$ & density of 0.809 & $\begin{array}{l}\text { /cc and a gas-o } \\
\text {, (2) liquid phas }\end{array}$ & $\begin{array}{l}\text { il ratio (GOR) of } \\
\mathrm{se}=184.503 \mathrm{~g} / \mathrm{n}\end{array}$ & 34.4 scf/STB. T & The average mo & $\begin{array}{l}\text { olecular weight } \\
\text { ase combine = }\end{array}$ \\
\hline
\end{tabular}


Table B.2. Composition of Anasazi No. 5-L separator oil cylinder No. W4635 at $73^{\circ} \mathrm{F}\left(23^{\circ} \mathrm{C}\right)$ and 1,014 psia (6,992 kpa).

\begin{tabular}{|c|c|c|c|c|c|c|}
\hline goming nent & Werghtginojer & Wras & 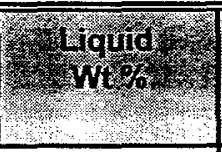 & (7) reral & Frolex & $\begin{array}{l}\text { Group mol } \\
\%\end{array}$ \\
\hline $\mathrm{CO}_{2}$ & 44.010 & 0.000 & 0.000 & 0.000 & 0.000 & 0.000 \\
\hline $\mathrm{H}_{2} \mathrm{~S}$ & 34.080 & 0.000 & 0.000 & 0.000 & 0.000 & 0.000 \\
\hline$N_{2}$ & 28.013 & 0.000 & 0.000 & 0.000 & 0.000 & 0.000 \\
\hline C1 & 16.043 & 12.873 & 0.000 & 0.062 & 0.683 & 0.683 \\
\hline C2 & 30.070 & 24.310 & 0.053 & 0.272 & 1.597 & 1.597 \\
\hline C3 & 44.097 & 30.619 & 0.392 & 0.793 & 3.171 & 3.171 \\
\hline $1-C 4$ & 58.124 & 5.583 & 0.239 & 0.334 & 1.011 & 1.011 \\
\hline N-C4 & 58.124 & 14.542 & 0.975 & 1.217 & 3.689 & 3.689 \\
\hline I-C5 & 72.151 & 3.602 & 0.793 & 0.861 & 2.102 & 2.102 \\
\hline N-C5 & 72.151 & 4.093 & 1.256 & 1.328 & 3.244 & 3.244 \\
\hline C6 & 86.200 & 2.238 & 2.767 & 2.788 & 5.700 & \\
\hline MCYCL-C5 & 84.160 & 0.417 & 0.768 & 0.768 & 1.609 & 9.243 \\
\hline Benzene & 78.110 & 0.106 & 0.178 & 0.178 & 0.402 & \\
\hline CYCL-C6 & 84.160 & 0.272 & 0.717 & 0.714 & 1.532 & \\
\hline $\mathrm{C7}$ & 100.200 & 0.659 & 3.284 & 3.26 & 5.734 & \multirow{8}{*}{23.114} \\
\hline MCYCL-C6 & 98.190 & 0.217 & 1.466 & 1.453 & 2.608 & \\
\hline Toluene & 92.140 & 0.060 & 0.456 & 0.452 & 0.864 & \\
\hline $\mathrm{C} 8$ & 114.230 & 0.253 & 4.306 & 4.257 & 6.568 & \\
\hline C2-Benzene & 106.170 & 0.011 & 0.176 & 0.174 & 0.289 & \\
\hline M\&P-XYLENE & 106.170 & 0.018 & 0.500 & 0.494 & 0.82 & \\
\hline O-XYLENE & 106.170 & 0.004 & 0.360 & 0.355 & 0.59 & \\
\hline $\mathrm{Cg}$ & 128.300 & 0.073 & 4.160 & 4.107 & 5.642 & \\
\hline C10 & 134.000 & 0.029 & 5.006 & 4.941 & 6.498 & \multirow{5}{*}{23.721} \\
\hline $\mathrm{C} 11$ & 147.000 & 0.009 & 4.447 & 4.388 & 5.261 & \\
\hline $\mathrm{C} 12$ & 161.000 & 0.004 & 3.732 & 3.683 & 4.031 & \\
\hline $\mathrm{C} 13$ & 175.000 & 0.003 & 4.373 & 4.315 & 4.345 & \\
\hline $\mathrm{C} 14$ & 190.000 & 0.001 & 3.919 & 3.867 & 3.587 & \\
\hline
\end{tabular}


Table B.2. (continued)

\begin{tabular}{|c|c|c|c|c|c|c|}
\hline Component & $\begin{array}{l}\text { Wolecular } \\
\text { Weight ginole) }\end{array}$ & $\begin{array}{l}\text { Gas } \\
\text { Mole \% } \\
\end{array}$ & (3) & $\begin{array}{l}\text { Oyerail } \\
\text { Wt }\end{array}$ & 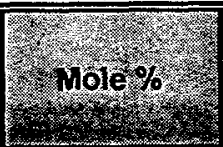 & Group nole \\
\hline C15: & 206.000 & 0.000 & 3.610 & 3.562 & 3.047 & \multirow{5}{*}{11.822} \\
\hline c16 & 222.000 & 0.000 & 3.104 & 3.063 & 2.431 & \\
\hline C17 & 237.000 & 0.000 & 3.089 & 3.048 & 2.266 & \\
\hline$C 18$ & 251.000 & 0.000 & 3.111 & 3.070 & 2.155 & \\
\hline C19 & 263.000 & 0.000 & 2.907 & 2.868 & 1.922 & \\
\hline $\mathrm{C} 20$ & 275.000 & 0.000 & 2.647 & 2.612 & 1.674 & \multirow{10}{*}{10.686} \\
\hline $\mathrm{C} 21$ & 291.000 & 0.000 & 2.362 & 2.331 & 1.411 & \\
\hline $\mathrm{C}_{22}$ & 305.000 & 0.000 & 2.319 & 2.288 & 1.322 & \\
\hline C23 & 318.000 & 0.000 & 2.152 & 2.123 & 1.177 & \\
\hline$C 24$ & 331.000 & 0.000 & 1.950 & 1.924 & 1.024 & \\
\hline$C 25$ & 345.000 & 0.000 & 1.929 & 1.903 & 0.972 & \\
\hline$C 26$ & 359.000 & 0.000 & 1.783 & 1.759 & 0.864 & \\
\hline$C 27$ & 374.000 & 0.000 & 1.844 & 1.819 & 0.857 & \\
\hline $\mathrm{C} 28$ & 388.000 & 0.000 & 1.693 & 1.670 & 0.759 & \\
\hline C29 & 402.000 & 0.000 & 1.447 & 1.427 & 0.625 & \\
\hline $\mathrm{C} 30+$ & 580.000 & 0.000 & 19.372 & 19.470 & 5.916 & 5.916 \\
\hline
\end{tabular}


Table B.3. Composition of Anasazi No. 5-L separator gas cylinder No. 5EK088.

\begin{tabular}{|c|c|c|c|c|c|}
\hline $\begin{array}{l}\text { (1) } \\
\text { conponent }\end{array}$ & $\begin{array}{l}\text { Molecular } \\
\text { Weight } \\
\text { (ginole) }\end{array}$ & 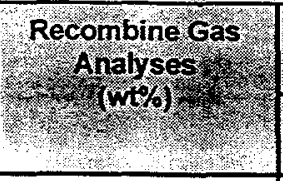 & 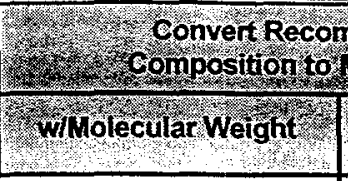 & 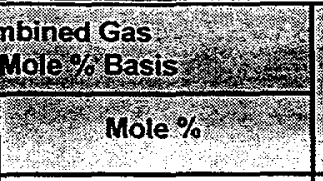 & 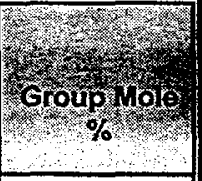 \\
\hline $\mathrm{CO}_{2}$ & 44.010 & 0.103 & 0.002 & 0.062 & 0.062 \\
\hline $\mathrm{H}_{2} \mathrm{~S}$ & 34.080 & 0.000 & 0.000 & 0.000 & 0.000 \\
\hline $\mathrm{N}_{2}$ & 28.013 & 10.570 & 0.038 & 1.002 & 1.002 \\
\hline $\mathrm{C}_{1}$ & 16.043 & 35.181 & 2.193 & 58.211 & 58.211 \\
\hline $\mathrm{C} 2$ & 30.070 & 23.285 & 0.774 & 20.555 & 20.555 \\
\hline C3 & 44.097 & 19.624 & 0.445 & 11.813 & 11.813 \\
\hline $\mathrm{I}-\mathrm{C}_{4}$ & 58.124 & 3.485 & 0.060 & 1.592 & 1.592 \\
\hline $\mathrm{N}-\mathrm{C} 4$ & 58.124 & 8.472 & 0.146 & 3.869 & 3.869 \\
\hline $1-C 5$ & 72.151 & 2.158 & 0.030 & 0.794 & 0.794 \\
\hline $\mathrm{N}-\mathrm{C} 5$ & 72.151 & 2.524 & 0.035 & 0.928 & 0.928 \\
\hline C6 & 86.200 & 1.797 & 0.021 & 0.553 & \multirow{4}{*}{0.759} \\
\hline MCYCL-C5 & 84.160 & 0.337 & 0.004 & 0.106 & \\
\hline Benzene & 78.110 & 0.083 & 0.001 & 0.028 & \\
\hline CYCL-C6 & 84.160 & 0.225 & 0.003 & 0.071 & \\
\hline $\mathrm{C} 7$ & 100.200 & 0.717 & 0.007 & 0.190 & \multirow{8}{*}{0.395} \\
\hline MCYCL-C6 & 98.190 & 0.232 & 0.002 & 0.063 & \\
\hline Toluene & 92.140 & 0.063 & 0.001 & 0.018 & \\
\hline $\mathrm{CB}$ & 114.230 & 0.359 & 0.003 & 0.083 & \\
\hline C2-Benzene & 106.170 & 0.015 & 0.000 & 0.004 & \\
\hline M\&P-XYLENE & 106.170 & 0.025 & 0.000 & 0.006 & \\
\hline O-XYLENE & 106.170 & 0.012 & 0.000 & 0.003 & \\
\hline $\mathrm{Cg}$ & 128.300 & 0.133 & 0.001 & 0.028 & \\
\hline C10 & 134.000 & 0.066 & 0.000 & 0.013 & \multirow{5}{*}{0.020} \\
\hline$C_{11}$ & 147.000 & 0.024 & 0.000 & 0.004 & \\
\hline $\mathrm{C}_{12}$ & 161.000 & 0.009 & 0.000 & 0.001 & \\
\hline C13 & 175.000 & 0.004 & 0.000 & 0.001 & \\
\hline C14 & 190.000 & 0.001 & 0.000 & 0.000 & \\
\hline C15 & 206.000 & 0.001 & 0.000 & 0.000 & \\
\hline C16 & 222.000 & 0.001 & 0.000 & 0.000 & \\
\hline C17 & 237.000 & 0.002 & 0.000 & 0.000 & \\
\hline C18 & 251.000 & 0.002 & 0.000 & 0.000 & \\
\hline C19 & 263.000 & 0.005 & 0.000 & 0.000 & \\
\hline
\end{tabular}

Average molecular weight of the gas in the sample $=26.54 \mathrm{~g} / \mathrm{mole}$. 
Table B.4. Composition of Anasazi No. 5-L separator gas cylinder No. 6EK087.

\begin{tabular}{|c|c|c|c|c|c|}
\hline 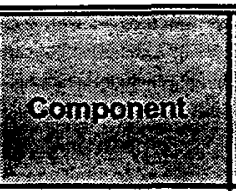 & 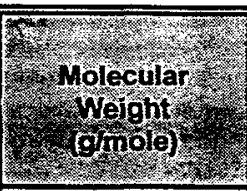 & 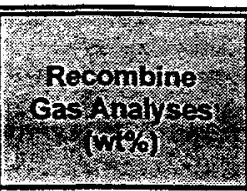 & 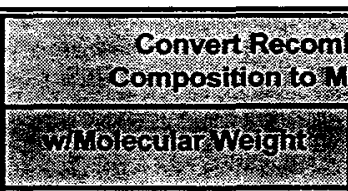 & 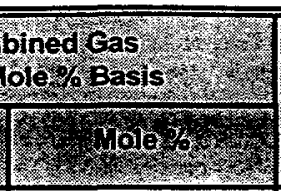 & 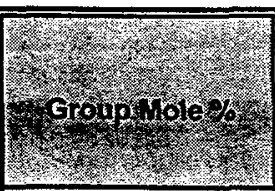 \\
\hline $\mathrm{CO}_{2}$ & 44.010 & 0.109 & 0.002 & 0.065 & 0.065 \\
\hline $\mathrm{H}_{2} \mathrm{~S}$ & 34.080 & 0.000 & 0.000 & 0.000 & 0.000 \\
\hline $\mathbf{N}_{2}$ & 28.013 & 1.053 & 0.038 & 0.997 & 0.997 \\
\hline C1 & 16.043 & 35.166 & 2.192 & 58.149 & 58.149 \\
\hline $\mathrm{C} 2$ & 30.070 & 23.461 & 0.780 & 20.698 & 20.698 \\
\hline C3 & 44.097 & 19.518 & 0.443 & 11.742 & 11.742 \\
\hline $1-C_{4}$ & 58.124 & 3.560 & 0.061 & 1.625 & 1.625 \\
\hline $\mathrm{N}-\mathrm{C}_{4}$ & 58.124 & 8.474 & 0.146 & 3.867 & 3.867 \\
\hline $1-C 5$ & 72.151 & 2.149 & 0.030 & 0.790 & 0.790 \\
\hline N-C5 & 72.151 & 2.506 & 0.035 & 0.921 & 0.921 \\
\hline C6 & 86.200 & 1.767 & 0.020 & 0.544 & \multirow{4}{*}{0.744} \\
\hline MCYCL-C5 & 84.160 & 0.329 & 0.004 & 0.104 & \\
\hline Benzene & 78.110 & 0.081 & 0.001 & 0.027 & \\
\hline CYCL-C6 & 84.160 & 0.220 & 0.003 & 0.069 & \\
\hline $\mathrm{C7}$ & 100.200 & 0.696 & 0.007 & 0.184 & \multirow{8}{*}{0.382} \\
\hline MCYCL-C6 & 98.190 & 0.224 & 0.002 & 0.061 & \\
\hline Toluene & 92.140 & 0.060 & 0.001 & 0.017 & \\
\hline $\mathrm{C} 8$ & 114.230 & 0.346 & 0.003 & 0.080 & \\
\hline C2-Benzene & 106.170 & 0.015 & 0.000 & 0.004 & \\
\hline M\&P-XYLENE & 106.170 & 0.026 & 0.000 & 0.007 & \\
\hline O-XYLENE & 106.170 & 0.010 & 0.000 & 0.002 & \\
\hline $\mathrm{Cg}$ & 128.300 & 0.128 & 0.001 & 0.027 & \\
\hline C10 & 134.000 & 0.062 & 0.000 & 0.012 & \multirow{5}{*}{0.018} \\
\hline C11 & 147.000 & 0.022 & 0.000 & 0.004 & \\
\hline C12 & 161.000 & 0.008 & 0.000 & 0.001 & \\
\hline C13 & 175.000 & 0.004 & 0.000 & 0.001 & \\
\hline C14 & 190.000 & 0.002 & 0.000 & 0.000 & \\
\hline$C_{15}$ & 206.000 & 0.001 & 0.000 & 0.000 & \\
\hline$C_{16}$ & 222.000 & 0.001 & 0.000 & 0.000 & \\
\hline C17 & 237.000 & 0.001 & 0.000 & 0.000 & \\
\hline C18 & 251.00 & 0.000 & 0.000 & 0.000 & \\
\hline C19 & 263.000 & 0.002 & 0.000 & 0.000 & \\
\hline
\end{tabular}


Table B.5. Dead oil liquid composition of the Anasazi flashed separator oils and dead oils.

\begin{tabular}{|c|c|c|c|c|c|c|}
\hline Component & $\begin{array}{c}\text { Molecular } \\
\text { Weight } \\
\text { ginole) } \\
\end{array}$ & $\begin{array}{l}\text { Cylinder } \\
\text { No W4635. } \\
\text { (wto }\end{array}$ & $\begin{array}{l}\text { Cylinder } \\
\text { No. w8301: } \\
\text { (w/ }\end{array}$ & 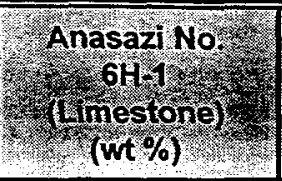 & 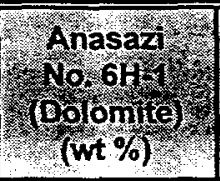 & 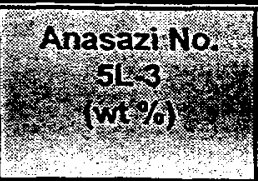 \\
\hline $\mathrm{CO}_{2}$ & 44.010 & 0.000 & 0.000 & 0.000 & 0.000 & 0.000 \\
\hline $\mathrm{H}_{2} \mathrm{~S}$ & 34.080 & 0.000 & 0.000 & 0.000 & 0.000 & 0.000 \\
\hline $\mathrm{N}_{2}$ & 28.013 & 0.000 & 0.000 & 0.000 & 0.000 & 0.000 \\
\hline C1 & 16.043 & 0.000 & 0.000 & 0.000 & 0.000 & 0.000 \\
\hline $\mathrm{C} 2$ & 30.070 & 0.053 & 0.050 & 0.001 & 0.022 & 0.049 \\
\hline $\mathrm{C} 3$ & 44.097 & 0.392 & 0.382 & 0.009 & 0.145 & 0.343 \\
\hline 1-C4 & 58.124 & 0.239 & 0.236 & 0.009 & 0.093 & 0.212 \\
\hline $\mathrm{N}-\mathrm{C} 4$ & 58.124 & 0.975 & 0.966 & 0.035 & 0.383 & 0.870 \\
\hline $1-C 5$ & 72.151 & 0.793 & 0.791 & 0.049 & 0.383 & 0.745 \\
\hline $\mathrm{N}-\mathrm{C} 5$ & 72.151 & 1.256 & 1.253 & 0.082 & 0.694 & 1.196 \\
\hline $\mathrm{C} 6$ & 86.200 & 2.757 & 2.760 & 0.265 & 1.473 & 1.979 \\
\hline MCYCL-C5 & 84.160 & 0.768 & 0.767 & 0.206 & 1.127 & 1.504 \\
\hline Benzene & 78.110 & 0.178 & 0.177 & 0.024 & 0.134 & 0.175 \\
\hline CYCL-C6 & 84.160 & 0.717 & 0.715 & 0.137 & 0.614 & 0.714 \\
\hline C7 & 100.200 & 3.284 & 3.268 & 0.701 & 3.060 & 3.293 \\
\hline MCYCL-C6 & 98.190 & 1.466 & 1.460 & 0.366 & 1.406 & 1.472 \\
\hline Toluene & 92.140 & 0.456 & 0.453 & 0.108 & 0.413 & 0.454 \\
\hline $\mathrm{C} 8$ & 114.230 & 4.306 & 4.270 & 1.286 & 4.206 & 4.335 \\
\hline C2-Benzene & 106.170 & 0.176 & 0.176 & 0.105 & 0.176 & 0.477 \\
\hline M\&P-XYLENE & 106.170 & 0.500 & 0.497 & 0.413 & 0.472 & 0.500 \\
\hline O-XYLENE & 106.170 & 0.360 & 0.343 & 0.323 & 0.331 & 0.362 \\
\hline $\mathrm{Cg}$ & 128.300 & 4.160 & 4.137 & 1.538 & 4.066 & 4.154 \\
\hline $\mathrm{C} 10$ & 134.000 & 5.006 & 4.996 & 2.529 & 4.881 & 4.913 \\
\hline $\mathrm{C}_{11}$ & 147.000 & 4.447 & 4.406 & 3.128 & 4.376 & 4.286 \\
\hline $\mathrm{C}_{12}$ & 161.000 & 3.732 & 3.751 & 3.284 & 4.737 & 3.635 \\
\hline $\mathrm{C} 13$ & 175.000 & 4.373 & 4.336 & 4.301 & 4.347 & 4.138 \\
\hline$C_{14}$ & 190.000 & 3.919 & 3.868 & 3.994 & 3.924 & 3.652 \\
\hline C15 & 206.000 & 3.610 & 3.615 & 3.943 & 3.701 & 3.208 \\
\hline C16 & 222.000 & 3.104 & 3.052 & 3.427 & 3.124 & 2.830 \\
\hline C17 & 237.000 & 3.089 & 3.039 & 3.336 & 3.082 & 2.763 \\
\hline C18 & 251.000 & 3.111 & 3.086 & 3.494 & 3.152 & 2.823 \\
\hline
\end{tabular}


Table B.5. (continued)

\begin{tabular}{|c|c|c|c|c|c|c|}
\hline Component & $\begin{array}{l}\text { Molecular } \\
\text { Weight } \\
\text { (gimolo) }\end{array}$ & $\begin{array}{l}\text { Cylinder } \\
\text { No. w4635 } \\
y \text { ty }\end{array}$ & $\begin{array}{l}\text { Cylinder } \\
\text { Yol } \\
(0.8301 \\
\end{array}$ & 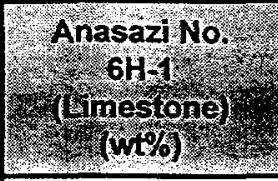 & 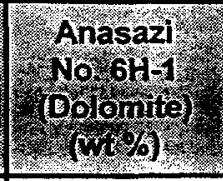 & 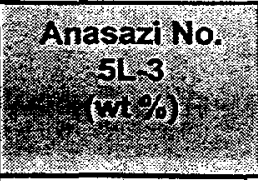 \\
\hline $\mathrm{C}_{19}$ & 263.000 & 2.907 & 2.891 & 3.160 & 2.987 & 2.596 \\
\hline $\mathrm{C}_{2} \mathrm{O}$ & 275.000 & 2.647 & 2.643 & 2.825 & 2.401 & 2.375 \\
\hline $\mathrm{C} 21$ & 291.000 & 2.362 & 2.346 & 2.660 & 2.360 & 2.101 \\
\hline $\mathrm{C}_{22}$ & 305.000 & 2.319 & 2.295 & 2.635 & 2.295 & 2.058 \\
\hline $\mathrm{C} 23$ & 318.000 & 2.152 & 2.134 & 2.468 & 2.155 & 1.922 \\
\hline $\mathrm{C} 24$ & 331.000 & 1.950 & 1.947 & 2.304 & 1.917 & 1.729 \\
\hline $\mathrm{C} 25$ & 345.000 & 1.929 & 1.888 & 2.277 & 2.229 & 1.692 \\
\hline $\mathrm{C} 26$ & 359.000 & 1.783 & 1.755 & 1.954 & 1.378 & 1.437 \\
\hline $\mathrm{C} 27$ & 374.000 & 1.844 & 1.725 & 2.275 & 1.782 & 1.549 \\
\hline $\mathrm{C} 28$ & 388.000 & 1.693 & 1.639 & 1.944 & 1.473 & 1.573 \\
\hline $\mathrm{C} 29$ & 402.000 & 1.446 & 1.519 & 1.740 & 1.521 & 1.300 \\
\hline $\mathrm{C} 30+$ & 580.000 & 19.732 & 20.371 & 36.664 & 23.980 & 24.885 \\
\hline$(\mathrm{g} / \mathrm{m}$ & les & 186.634 & 184.503 & 272.062 & 200.546 & 189.014 \\
\hline
\end{tabular}


Table B.6. Composition of Anasazi No. 5-L recombined separator oil at $70^{\circ} \mathrm{F}\left(21^{\circ} \mathrm{C}\right)$ and 3,014 psia (20,782 kpa).

\begin{tabular}{|c|c|c|c|c|c|c|}
\hline Component & $\begin{array}{l}\text { Molecular } \\
\text { Weight } \\
\text { (glmole) }\end{array}$ & $\begin{array}{l}\text { Gas } \\
\text { Mole\% } \% \text {, }\end{array}$ & 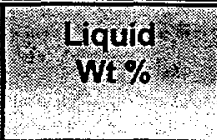 & overall & Frole \% & $\begin{array}{l}\text { Goup } \\
\text { Mole } \% \text { \% }\end{array}$ \\
\hline $\mathrm{CO}_{2}$ & 44.010 & 0.078 & 0.000 & 0.031 & 0.055 & 0.055 \\
\hline $\mathrm{H}_{2} \mathrm{~S}$ & 34.080 & 0.000 & 0.000 & 0.000 & 0.000 & 0.000 \\
\hline $\mathrm{N}_{2}$ & 28.013 & 1.003 & 0.000 & 0.255 & 0.702 & 0.702 \\
\hline C1 & 16.043 & 55.141 & 0.011 & 8.052 & 38.647 & 38.647 \\
\hline $\mathrm{C} 2$ & 30.070 & 19.748 & 0.076 & 5.456 & 13.971 & 13.941 \\
\hline C3 & 44.097 & 12.165 & 0.274 & 5.080 & 8.872 & 8.872 \\
\hline $1-C_{4}$ & 58.124 & 1.902 & 0.143 & 1.111 & 1.472 & 1.472 \\
\hline $\mathrm{N}-\mathrm{C} 4$ & 58.124 & 4.792 & 0.565 & 2.951 & 3.909 & 3.909 \\
\hline $1-C 5$ & 72.151 & 1.241 & 0.481 & 1.170 & 1.249 & 1.249 \\
\hline $\mathrm{N}-\mathrm{C} 5$ & 72.151 & 1.561 & 0.829 & 1.637 & 1.748 & 1.748 \\
\hline C6 & 86.200 & 1.123 & 2.404 & 2.659 & 2.375 & \multirow{4}{*}{3.562} \\
\hline MCYCL-C5 & 84.160 & 0.194 & 0.601 & 0.594 & 0.543 & \\
\hline Benzene & 78.110 & 0.051 & 0.142 & 0.142 & 0.140 & \\
\hline CYCL-C6 & 84.160 & 0.135 & 0.605 & 0.551 & 0.504 & \\
\hline C7 & 100.200 & 0.397 & 3.247 & 2.765 & 2.125 & \multirow{8}{*}{$\quad 8.257$} \\
\hline MCYCL-C6 & 98.190 & 0.128 & 1.390 & 1.143 & 0.896 & \\
\hline Toluene & 92.140 & 0.037 & 0.442 & 0.358 & 0.299 & \\
\hline $\mathrm{C} 8$ & 114.230 & 0.170 & 4.465 & 3.480 & 2.346 & \\
\hline C2-Benzene & 106.170 & 0.008 & 0.165 & 0.130 & 0.094 & \\
\hline M\&P-XYLENE & 106.170 & 0.013 & 0.521 & 0.398 & 0.289 & \\
\hline O-XYLENE & 106.170 & 0.005 & 0.383 & 0.288 & 0.209 & \\
\hline C9 & 128.300 & 0.056 & 4.412 & 3.330 & 1.999 & \\
\hline c10 & 134.000 & 0.027 & 5.293 & 3.950 & 2.270 & \multirow{5}{*}{8.092} \\
\hline C11 & 147.000 & 0.011 & 4.617 & 3.432 & 1.798 & \\
\hline$C_{12}$ & 161.000 & 0.005 & 3.851 & 2.857 & 1.367 & \\
\hline$C 13$ & 175.000 & 0.003 & 4.500 & 3.335 & 1.467 & \\
\hline C14 & 190.000 & 0.002 & 3.965 & 2.937 & 1.191 & \\
\hline C15 & 206.000 & 0.002 & 3.644 & 2.700 & 1.009 & \multirow{5}{*}{3.959} \\
\hline C16 & 222.000 & 0.001 & 3.175 & 2.352 & 0.816 & \\
\hline C17 & 237.000 & 0.001 & 3.139 & 2.324 & 0.755 & \\
\hline C18 & 251.000 & 0.000 & 3.218 & 2.382 & 0.731 & \\
\hline$L_{10}$ & 263000 & 0000 & 2991 & 2214 & 0648 & \\
\hline
\end{tabular}


Table B.6. (continued)

\begin{tabular}{|c|c|c|c|c|c|c|}
\hline Component & $\begin{array}{c}\text { Molecular } \\
\text { Woight } \\
\text { cinole) }\end{array}$ & $\begin{array}{l}\text { Gas } \\
\text { mole\% }\end{array}$ & (1) & Pyerall & - Wole 6 & $\begin{array}{l}\text { Group } \\
\text { uole\% }\end{array}$ \\
\hline $\mathrm{C} 20$ & 275.000 & 0.000 & 2.651 & 1.962 & 0.549 & \multirow{10}{*}{3.509} \\
\hline $\mathrm{C} 21$ & 291.000 & 0.000 & 2.413 & 1.786 & 0.473 & \\
\hline $\mathrm{C} 22$ & 305.000 & 0.000 & 2.351 & 1.740 & 0.439 & \\
\hline $\mathrm{C}_{23}$ & 318.000 & 0.000 & 2.205 & 1.632 & 0.395 & \\
\hline $\mathrm{C} 24$ & 331.000 & 0.000 & 1.971 & 1.459 & 0.339 & \\
\hline $\mathrm{C} 25$ & 345.000 & 0.000 & 1.938 & 1.434 & 0.320 & \\
\hline $\mathrm{C} 26$ & 359.000 & 0.000 & 1.687 & 1.248 & 0.268 & \\
\hline $\mathrm{C} 27$ & 374.000 & 0.000 & 1.842 & 1.363 & 0.281 & \\
\hline $\mathrm{C} 28$ & 388.000 & 0.000 & 1.552 & 1.149 & 0.228 & \\
\hline C29 & 402.000 & 0.000 & 1.533 & 1.134 & 0.217 & \\
\hline $\mathrm{C} 30+$ & 580.000 & 0.000 & 20.309 & 15.029 & 1.995 & 1.995 \\
\hline
\end{tabular}


Table B.7. Composition of Anasazi No. 5-L recombined oil flashed to 2,050 psia (14,135 kpa) at $130^{\circ} \mathrm{F}\left(54^{\circ} \mathrm{C}\right)$.

\begin{tabular}{|c|c|c|c|c|c|c|}
\hline component & $\begin{array}{l}\text { Molecular } \\
\text { Weight } \\
\text { (g/mole) }\end{array}$ & $\begin{array}{c}\text { Gas } \\
\text { Mole } \%\end{array}$ & Priquid & $\begin{array}{l}\text { Overall } \\
\text { wt } \%\end{array}$ & Mole \% & Grovgr \\
\hline $\mathrm{CO}_{2}$ & 44.010 & 0.000 & 0.000 & 0.000 & 0.000 & 0.000 \\
\hline $\mathrm{H}_{2} \mathrm{~S}$ & 34.080 & 0.000 & 0.000 & 0.000 & 0.000 & 0.000 \\
\hline $\mathrm{N}_{2}$ & 28.013 & 0.928 & 0.000 & 0.191 & 0.586 & 0.586 \\
\hline c1 & 16.043 & 53.274 & 0.000 & 6.291 & 33.617 & 33.617 \\
\hline $\mathrm{C} 2$ & 30.070 & 22.122 & 0.087 & 4.965 & 14.157 & 14.157 \\
\hline $\mathrm{C} 3$ & 44.097 & 14.215 & 0.328 & 4.875 & 9.477 & 9.477 \\
\hline I-C4 & 58.124 & 2.023 & 0.232 & 1.050 & 1.549 & 1.549 \\
\hline $\mathrm{N}-\mathrm{C} 4$ & 58.124 & 4.668 & 1.005 & 2.796 & 4.125 & 4.125 \\
\hline 1-C5 & 72.151 & 0.872 & 0.832 & 1.125 & 1.336 & 1.336 \\
\hline $\mathrm{N}-\mathrm{C} 5$ & 72.151 & 0.960 & 1.346 & 1.580 & 1.878 & 1.878 \\
\hline $\mathrm{C} 6$ & 86.200 & 0.488 & 3.043 & 2.730 & 2.715 & \multirow{4}{*}{4.078} \\
\hline MCYCL-C5 & 84.160 & 0.079 & 0.709 & 0.613 & 0.624 & \\
\hline Benzene & 78.110 & 0.021 & 0.165 & 0.143 & 0.157 & \\
\hline CYCL-C6 & 84.160 & 0.052 & 0.677 & 0.571 & 0.582 & \\
\hline$C 7$ & 100.200 & 0.141 & 3.451 & 2.849 & 2.437 & \multirow{8}{*}{$\because \quad 9.413$} \\
\hline MCYCL-C6 & 98.190 & 0.001 & 1.435 & 1.142 & 0.997 & \\
\hline Toluene & 92.140 & 0.012 & 0.449 & 0.365 & 0.340 & \\
\hline $\mathrm{CB}$ & 114.230 & 0.092 & 4.416 & 3.589 & 2.694 & \\
\hline C2-Benzene & 106.170 & 0.003 & 0.177 & 0.143 & 0.115 & \\
\hline M\&P-XYLENE & 106.170 & 0.005 & 0.502 & 0.403 & 0.325 & \\
\hline O-XYLENE & 106.170 & 0.002 & 0.555 & 0.443 & 0.358 & \\
\hline $\mathrm{Cg}$ & 128.300 & 0.020 & 4.015 & 3.212 & 2.146 & \\
\hline $\mathrm{C} 10$ & 134.000 & 0.013 & 5.055 & 4.033 & 2.581 & \multirow{5}{*}{9.275} \\
\hline C11 & 147.000 & 0.005 & 4.405 & 3.509 & 2.046 & \\
\hline $\mathrm{C} 12$ & 161.000 & 0.001 & 3.759 & 2.991 & 1.593 & \\
\hline $\mathrm{C} 13$ & 175.000 & 0.000 & 4.351 & 3.461 & 1.696 & \\
\hline C14 & 190.000 & 0.000 & 3.789 & 3.014 & 1.360 & \\
\hline C15 & 206.000 & 0.000 & 3.520 & 2.800 & 1.165 & \multirow{5}{*}{4.507} \\
\hline$C_{16}$ & 222.000 & 0.000 & 3.003 & 2.389 & 0.923 & \\
\hline C17 & 237.000 & 0.000 & 2.963 & 2.357 & 0.853 & \\
\hline C18 & 251.000 & 0.000 & 3.029 & 2.409 & 0.823 & \\
\hline C19 & 263.000 & 0.000 & 2.867 & 2.280 & 0.743 & \\
\hline
\end{tabular}


Table B.7. (continued)

\begin{tabular}{|c|c|c|c|c|c|c|}
\hline Component & $\begin{array}{c}\text { Molecular } \\
\text { Weight } \\
\text { (ginole) }\end{array}$ & Gas $\%$ & $\begin{array}{l}\text { Uiquid } \\
\text { Wt \% }\end{array}$ & Overall & - Mole \% & $\begin{array}{l}\text { Group } \\
\text { Mole \% }\end{array}$ \\
\hline $\mathrm{C}_{20}$ & 275.000 & 0.000 & 2.307 & 1.835 & 0.572 & \\
\hline $\mathrm{C} 21$ & 291.000 & 0.000 & 2.290 & 1.821 & 0.537 & \\
\hline $\mathrm{C} 22$ & 305.000 & 0.000 & 2.240 & 1.781 & 0.501 & \\
\hline $\mathrm{C} 23$ & 318.000 & 0.000 & 2.094 & 1.665 & 0.449 & \\
\hline $\mathrm{C}_{24}$ & 331.000 & 0.000 & 1.879 & 1.494 & 0.387 & \multirow{2}{*}{3.996} \\
\hline $\mathrm{C} 25$ & 345.000 & 0.000 & 1.964 & 1.562 & 0.388 & \\
\hline $\mathrm{C} 26$ & 359.000 & 0.000 & 1.616 & 1.285 & 0.307 & \\
\hline $\mathrm{C} 27$ & 374.000 & 0.000 & 1.805 & 1.436 & 0.329 & \\
\hline $\mathrm{C} 28$ & 388.000 & 0.000 & 1.626 & 1.293 & 0.286 & \\
\hline $\mathrm{C} 29$ & 402.000 & 0.000 & 1.419 & 1.129 & 0.241 & \\
\hline $\mathrm{C} 30+$ & 580.000 & 0.000 & 20.596 & 16.380 & 2.006 & 2.006 \\
\hline
\end{tabular}

The sample had a density of $0.664 \mathrm{~g} / \mathrm{cc}$ and a GOR of $1,037 \mathrm{scf} / \mathrm{STB}$. The average molecular weight of the (1) gas phase $=27.811 \mathrm{~g} / \mathrm{mole}$, (2) liquid phase $=184.796 \mathrm{~g} / \mathrm{mole}$, and $(3)$ gas and liquid phase combined $=85.734$ $\mathrm{g} /$ mole. 
Table B.8. Vapor compositional data for the two separator tests.

\begin{tabular}{|c|c|c|c|}
\hline \begin{tabular}{|c|} 
Component \\
\end{tabular} & $\begin{array}{l}\text { Molecular Weight } \\
(\text { glmole) }\end{array}$ & $\begin{array}{l}35 \text { psig \& } 85 \% \text { ) } \\
\text { ist Stage (mole\%) }\end{array}$ & $\begin{array}{l}0 \text { psig \& } 60^{\circ} \mathrm{F} \\
\text { 2nd Stage (mole } \%)\end{array}$ \\
\hline $\mathrm{CO}_{2}$ & 44.010 & 0.000 & 3.983 \\
\hline $\mathrm{H}_{2} \mathrm{~S}$ & 34.080 & 0.000 & 0.000 \\
\hline $\mathrm{N}_{2}$ & 28.013 & 1.224 & 0.435 \\
\hline $\mathrm{C} 1$ & 16.043 & 58.890 & 25.500 \\
\hline $\mathrm{C} 2$ & 30.070 & 20.432 & 29.578 \\
\hline $\mathrm{C3}$ & 44.097 & 11.588 & 23.915 \\
\hline $1-C_{4}$ & 58.124 & 1.547 & 3.447 \\
\hline $\mathrm{N}-\mathrm{C} 4$ & 58.124 & 3.664 & 7.940 \\
\hline $1-C 5$ & 72.151 & 0.757 & 1.588 \\
\hline $\mathrm{N}-\mathrm{C} 5$ & 72.151 & 0.883 & 1.796 \\
\hline $\mathrm{C6}$ & 86.200 & 0.505 & 0.965 \\
\hline MCYCL-C5 & 84.160 & 0.083 & 0.149 \\
\hline Benzene & 78.110 & 0.022 & 0.047 \\
\hline CYCL-C6 & 84.160 & 0.056 & 0.098 \\
\hline $\mathrm{C7}$ & 100.200 & 0.160 & 0.263 \\
\hline MCYCL-C6 & 98.190 & 0.048 & 0.081 \\
\hline Toluene & 92.140 & 0.014 & 0.026 \\
\hline $\mathrm{C} 8$ & 114.230 & 0.059 & 0.118 \\
\hline C2-Benzene & 106.170 & 0.005 & 0.006 \\
\hline M\&P-XYLENE & 106.170 & 0.004 & 0.007 \\
\hline O-XYLENE & 106.170 & 0.001 & 0.001 \\
\hline C9 & 128.300 & 0.014 & 0.030 \\
\hline C10 & 134.000 & 0.005 & 0.009 \\
\hline C11 & 147.000 & 0.002 & 0.008 \\
\hline $\mathrm{C}_{12}$ & 161.000 & 0.002 & 0.003 \\
\hline $\mathrm{C} 13$ & 175.000 & 0.002 & 0.002 \\
\hline $\mathrm{C}_{14}$ & 190.000 & 0.001 & 0.002 \\
\hline C15 & 206.000 & 0.002 & 0.001 \\
\hline C16 & 222.000 & 0.000 & 0.001 \\
\hline$c_{17}$ & 237.000 & 0.001 & 0.001 \\
\hline $\mathrm{C} 18$ & 251.000 & 0.000 & 0.000 \\
\hline C19 & 263.000 & 0.000 & 0.001 \\
\hline
\end{tabular}

The Molecular weight of the 1 st stage sample was $26.19 \mathrm{~g} / \mathrm{mole}$ and the density was $0.0037 \mathrm{~g} / \mathrm{cc}$. The molecular

weight of the 2 nd stage sample was $36.14 \mathrm{~g} /$ mole and the density was $0.0014 \mathrm{~g} / \mathrm{cc}$.

Note: The component molecular weights listed in these tables and used to convert the measured weight fractions into mole fractions represent average values which account for n-paraffins as well as undefined carbon numbers (such as cyclo-paraffins or naphthenes) contained in the oil. These values were selected based on extensive experience with previously analyzed crude oils by D.B. Robinson Research Ltd. 


\title{
APPENDIX C
}

\author{
SWELLING TEST DATA \\ ANASAZI FIELD \\ NAVAJO NATION
SAN JUAN COUNTY, UTAH
}


Table C.1. Swelling test $\mathrm{CO}_{2}$ concentration data.

\begin{tabular}{|c|c|}
\hline Test No. & $\begin{array}{c}\mathrm{CO}_{2} \text { Concentration } \\
\text { (Mole \%) }\end{array}$ \\
\hline 1 & 0 \\
\hline 2 & 20 \\
\hline 3 & 40 \\
\hline 4 & 60 \\
\hline 5 & 75 \\
\hline
\end{tabular}

Table C.2. Relative volumes of the liquid and vapor phases as a function of pressure at $130^{\circ} \mathrm{F}\left(54^{\circ} \mathrm{C}\right)\left(\mathrm{CO}_{2}\right.$ concentration $=20$ mole percent $)$.

\begin{tabular}{||l|r|r|r|r|r||}
\hline $\begin{array}{c}\text { Pressure } \\
\text { (psig) }\end{array}$ & $\begin{array}{r}\text { Total Volume } \\
\left(\mathrm{cm}^{3}\right)\end{array}$ & $\begin{array}{r}\text { Relative Volume } \\
\left(\mathrm{cm}^{3}\left(\mathrm{~cm}^{3}\right)\right.\end{array}$ & \multicolumn{2}{|c|}{$\begin{array}{c}\text { Phase Volume }\left(\mathrm{cm}^{3}\right) \\
\text { Liquid }\end{array}$} & $\begin{array}{c}\text { Vapor } \\
\text { Observations }\end{array}$ \\
\hline 3,986 & 64.09 & 0.974 & 64.09 & 0.00 & single phase \\
\hline 3,486 & 64.61 & 0.981 & 64.61 & 0.00 & single phase \\
\hline 2,987 & 65.07 & 0.988 & 65.07 & 0.00 & single phase \\
\hline 2,487 & 65.64 & 0.997 & 65.64 & 0.00 & single phase \\
\hline 2,227 & 66.55 & 1.011 & 66.55 & 0.00 & single phase \\
\hline 2,177 & 67.11 & 1.019 & 64.31 & 2.80 & two phase \\
\hline 2,127 & 67.83 & 1.030 & 63.89 & 3.94 & two phase \\
\hline 1,986 & 70.07 & 1.064 & 62.32 & 7.75 & two phase \\
\hline
\end{tabular}

*Defined as the ratio of the total volume to the saturation volume 
Table C.3. Properties of the saturated fluid with 20 mole percent $\mathrm{CO}_{2}$ at $130^{\circ} \mathrm{F}\left(54^{\circ} \mathrm{C}\right)$.

\begin{tabular}{|l|c|}
\hline Saturation Pressure (psia) & $2,294.000$ \\
\hline Saturation Volume $\left(\mathrm{cm}^{3}\right)$ & 65.830 \\
\hline Bulk Density $\left(\mathrm{g} / \mathrm{cm}^{3}\right)$ & $0.678^{\star}$ \\
\hline Swelling Factor & $1.104^{\star \star}$ \\
\hline Viscosity $(\mathrm{cP})$ & $0.349^{\star}$ \\
\hline
\end{tabular}

*Measured at 50 psi ( $345 \mathrm{kpa}$ ) above actual bubble point pressure

"Defined as the ratio of the saturation volume of $\mathrm{CO}_{2} /$ oil mixture to that of the virgin oil $\left(59.61 \mathrm{~cm}^{3}\right)$

Table C.4. Relative volumes of the liquid and vapor phases as a function of pressure at $130^{\circ} \mathrm{F}\left(54^{\circ} \mathrm{C}\right)\left(\mathrm{CO}_{2}\right.$ concentration $=40$ mole percent $)$.

\begin{tabular}{|c|c|c|c|c|c|}
\hline Pressure & $\begin{array}{l}\text { Total Volume } \\
\left(\mathrm{cm}^{3}\right)\end{array}$ & $\begin{array}{l}\text { Relative Volume } \\
\left(\mathrm{cm}^{3} \mathrm{~cm}^{3}\right)\end{array}$ & $\begin{array}{l}\text { Phase Vol } \\
\text { Liquid }\end{array}$ & $\begin{array}{l}\text { ne }\left(\mathrm{cm}^{3}\right) \\
\text { V. Vapor }\end{array}$ & Observations \\
\hline 4,486 & 70.04 & 0.967 & 70.04 & 0.00 & single phase \\
\hline 3,987 & 70.61 & 0.975 & 71.61 & 0.00 & single phase \\
\hline 3,486 & 71.21 & 0.983 & 71.21 & 0.00 & single phase \\
\hline 2,986 & 71.97 & 0.993 & 71.97 & 0.00 & single phase \\
\hline 2,525 & 72.93 & 1.007 & not measureable & not measureable & two phase \\
\hline 2,430 & 73.73 & 1.018 & 60.46 & 4.69 & two phase \\
\hline 2,351 & 74.58 & 1.029 & 67.32 & 7.26 & two phase \\
\hline 1,986 & 80.99 & 1.118 & 61.84 & 19.15 & two phase \\
\hline
\end{tabular}

"Defined as the ratio of the total volume to the saturation volume 
Table C.5. Properties of the saturated fluid with 40 mole percent $\mathrm{CO}_{2}$ at $130^{\circ} \mathrm{F}\left(54^{\circ} \mathrm{C}\right)$.

\begin{tabular}{|l|c|}
\hline Saturation Pressure $(\mathrm{psia})$ & $2,585.000$ \\
\hline Saturation Volume $\left(\mathrm{cm}^{3}\right)$ & 72.450 \\
\hline Bulk Density $\left(\mathrm{g} / \mathrm{cm}^{3}\right)$ & $0.697^{\star}$ \\
\hline Gravimetric Density $\left(\mathrm{g} / \mathrm{cm}^{3}\right)$ & $0.693^{\star}$ \\
\hline Swelling Factor & $1.215^{\star \star}$ \\
\hline Viscosity (cP) & $0.270^{\star}$ \\
\hline
\end{tabular}

*Measured at 50 psi (345 kpa) above actual bubble point pressure

**Defined as the ratio of the saturation volume of $\mathrm{CO}_{2} /$ oil mixture to that of the virgin oil $\left(59.61 \mathrm{~cm}^{3}\right)$

Table C.6. Relative volumes of the liquid and vapor phases as a function of pressure at $130^{\circ} \mathrm{F}\left(54^{\circ} \mathrm{C}\right)\left(\mathrm{CO}_{2}\right.$ concentration $=60$ mole percent $)$.

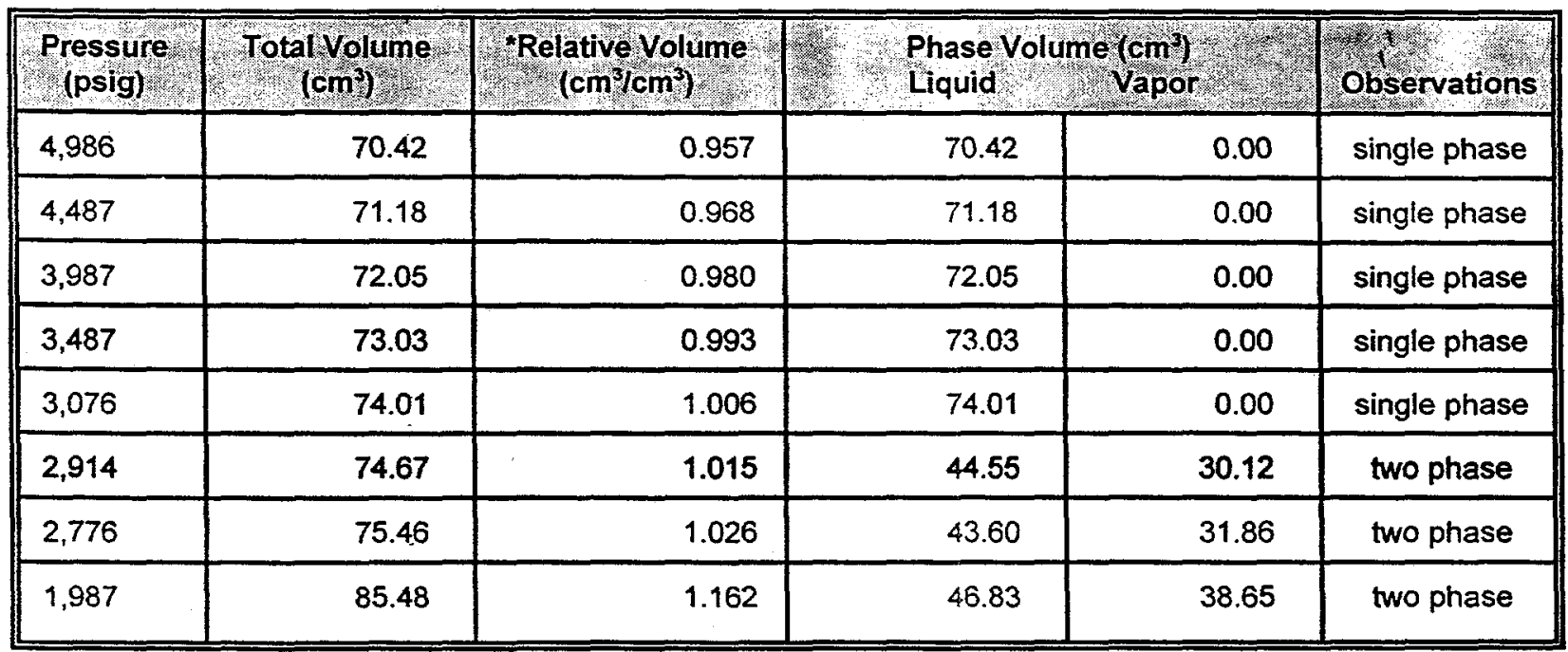

*Defined as the ratio of the total volume to the saturation volume 
Table C.7. Visual determination of the bubble point pressure using small pressure drops for the Anasazi oil with 60 mole percent $\mathrm{CO}_{2}$ concentration.

\begin{tabular}{|c|c|}
\hline Pressure (psig) & Observations \\
\hline 3,100 & clear single phase \\
\hline 3,090 & starting to cloud \\
\hline 3,075 & opaque \\
\hline 3,060 & two phase \\
\hline
\end{tabular}

Table C.8. Properties of the saturated fluid with 60 mole percent $\mathrm{CO}_{2}$ at $130^{\circ} \mathrm{F}\left(54^{\circ} \mathrm{C}\right)$.

\begin{tabular}{||c|c|}
\hline Graphical $P_{\text {sat }}$ (psia) & $3,176.000$ \\
\hline Visual $P_{\text {sat }}$ (psia) & $3,100.000$ \\
\hline Graphical $V_{\text {sat }}\left(\mathrm{cm}^{3}\right)$ & 73.550 \\
\hline Bulk Density $\left(\mathrm{g} / \mathrm{cm}^{3}\right)$ & $0.725^{\star}$ \\
\hline Swelling Factor & $1.234^{\star *}$ \\
\hline Viscosity (cP) & $0.215^{\star}$ \\
\hline
\end{tabular}

Measured at $50 \mathrm{psi}$ ( $345 \mathrm{kpa}$ ) above actual bubble point pressure

mefined as the ratio of the saturation volume of $\mathrm{CO}_{2} /$ oil mixture to that of the virgin oil $\left(59.61 \mathrm{~cm}^{3}\right)$ 
Table C.9. Relative volumes of the liquid and vapor phases as a function of pressure at $130^{\circ} \mathrm{F}\left(54^{\circ} \mathrm{C}\right)\left(\mathrm{CO}_{2}\right.$ concentration $=75$ mole percent $)$.

\begin{tabular}{|c|r|r|r|c|}
\hline \begin{tabular}{|c|} 
Pressure (psig) \\
\hline 7,986
\end{tabular} & $\begin{array}{r}\text { Total Volume } \\
\left(\mathbf{c m}^{3}\right)\end{array}$ & $\begin{array}{r}\text { Relative Volume } \\
\left(\mathbf{c m}^{3} / \mathbf{c m}^{3}\right)\end{array}$ & $\begin{array}{c}\text { \% Liquid } \\
\text { Observations }\end{array}$ \\
\hline 7,486 & 75.43 & 0.965 & 0.00 & single phase \\
\hline 6,986 & 75.69 & 0.968 & 0.00 & single phase \\
\hline 6,487 & 76.49 & 0.978 & 0.00 & single phase \\
\hline 5,986 & 77.07 & 0.986 & 0.00 & single phase \\
\hline 5,487 & 77.87 & 0.996 & $: 0.00$ & single phase \\
\hline 4,987 & 78.76 & 1.007 & not measureable & two phase \\
\hline 4,486 & 79.72 & 1.019 & 1.25 & two phase \\
\hline 3,986 & 80.90 & 1.035 & 4.94 & two phase \\
\hline 3,486 & 82.36 & 1.053 & 10.32 & two phase \\
\hline 2,986 & 84.05 & 1.075 & 16.42 & two phase \\
\hline 2,486 & 86.43 & 1.105 & 21.75 & two phase \\
\hline 2,036 & 90.46 & 1.157 & 26.86 & two phase \\
\hline & 98.23 & 1.256 & 29.83 & two phase \\
\hline
\end{tabular}

*Defined as the ratio of the total volume to the saturation volume

Table C.10. Properties of the saturated fluid with 75 mole percent $\mathrm{CO}_{2}$ at $130^{\circ} \mathrm{F}\left(54^{\circ} \mathrm{C}\right)$.

\begin{tabular}{|l|c|}
\hline Visual $P_{\text {sat }}$ (psia) & $5,800.000$ \\
\hline Saturation Volume $\left(\mathrm{cm}^{3}\right)$ & 78.200 \\
\hline Bulk Density $\left(\mathrm{g} / \mathrm{cm}^{3}\right)$ & $0.805^{\star}$ \\
\hline Swelling Factor & $1.215^{\star *}$ \\
\hline Viscosity (cP) & 0.210 \\
\hline
\end{tabular}

"Measured at 50 psi ( $345 \mathrm{kpa}$ ) above actual bubble point pressure

*Defined as the ratio of the saturation volume of $\mathrm{CO}_{2} /$ oil mixture to that of the virgin oil $\left(59.61 \mathrm{~cm}^{3}\right)$ 